\title{
Determinants of intraday dynamics and collateral selection in centrally cleared and bilateral repos
}

Article

Accepted Version

Creative Commons: Attribution-Noncommercial-No Derivative Works 4.0

Dufour, A., Marra, M. and Sangiorgi, I. (2019) Determinants of intraday dynamics and collateral selection in centrally cleared and bilateral repos. Journal of Banking \& Finance, 107. 105610. ISSN 0378-4266 doi:

https://doi.org/10.1016/j.jbankfin.2019.105610 Available at https://centaur.reading.ac.uk/85592/

It is advisable to refer to the publisher's version if you intend to cite from the work. See Guidance on citing.

To link to this article DOI: http://dx.doi.org/10.1016/j.jbankfin.2019.105610

Publisher: Elsevier

All outputs in CentAUR are protected by Intellectual Property Rights law, including copyright law. Copyright and IPR is retained by the creators or other copyright holders. Terms and conditions for use of this material are defined in the End User Agreement.

www.reading.ac.uk/centaur 
Central Archive at the University of Reading

Reading's research outputs online 


\section{Determinants of intraday dynamics and collateral selection in}

\section{centrally cleared and bilateral repos}

Alfonso Dufour ${ }^{\mathrm{a}}$, Miriam Marra ${ }^{\mathrm{a}}$ and Ivan Sangiorgi ${ }^{\mathrm{a}, *}$

This version: 7 August 2019

a ICMA Centre, Henley Business School, University of Reading, Whiteknights, Reading RG6 6BA, $U K$

Alfonso Dufour: a.dufour@icmacentre.ac.uk, +44 (0) 1183786430

Miriam Marra: m.marra@icmacentre.ac.uk, +44 (0) 1183786924

Ivan Sangiorgi: ivan.sangiorgi@icmacentre.ac.uk, +44 (0) 1183784373 (*corresponding author) 


\title{
Determinants of intraday dynamics and collateral selection
}

\author{
in centrally cleared and bilateral repos
}

\begin{abstract}
Using a novel dataset, we study intraday trades of overnight general collateral repurchase agreements (repos) on Italian government bonds. We focus both on repos cleared by central counterparties (CCPs) and traded bilaterally. Intraday bond supply, liquidity and duration significantly affect the spread of repo rates over the European Central Bank (ECB) deposit rate, but after the ECB quantitative easing interventions this impact is much reduced. During the European sovereign debt crisis, the increase in margins further deteriorates repo costs, creating a negative procyclical effect. Once we control for the impact of margin costs, CCP-based repos do not appear to be significantly cheaper than bilateral repos. We also show that bonds with lower liquidity and specialness, greater supply and longer duration are more likely to be selected as collateral. However, during the crisis, CCP-repo borrowers choose collateral bonds with higher liquidity and lower duration to reduce margin and repo trading costs.

JEL classification: E43; E51; G01; G12; G15; G24
\end{abstract}

Keywords: Repurchase agreement; Intraday repo rate; Bond collateral; Funding liquidity; Central counterparty clearing; Counteparty credit risk 


\section{Introduction}

Overnight (ON) general collateral (GC) repurchase agreements (repos) are the most common financial instruments used by banks to raise short-term loans backed by collateral, such as government bonds, and to efficiently manage intraday liquidity at lower interest rates than in the ON unsecured markets. Before the 2007-2008 financial crisis repos were largely ignored, until a seizure in the market triggered panic and played a key role in the crisis development. After that event and the resulting European sovereign debt crisis (ESDC), the European Central Bank (ECB) started a policy of massive bond purchases which has made repo collateral scarcer. ${ }^{1}$ In addition, new regulation has encouraged repo trading to shift to central clearing counterparties (CCPs).

Given the centrality of the topic, in this paper we study intraday ON GC repos, both cleared by CCPs and traded bilaterally, to provide a better understanding of the mechanisms behind this market that can inform banks' intraday borrowing decisions and collateral selection. We address the following questions: Does the cost of an ON GC repo change over the day and what is the expected pattern? Which factors determine the variation of the intraday ON GC repo cost and do they have a different impact during periods of higher and lower market stress and central bank intervention? Is there any significant difference between CCP-based and bilaterally-traded repos? How do repo borrowers choose which bond to deliver as collateral depending on the type of repo contract (CCPbased or bilateral) and the market conditions?

We look at repos traded on MTS (Mercato dei Titoli di Stato) that use Italian government bonds as collateral, over the period from January 2010 to November 2015. The MTS repo market is one of the largest electronic markets in Europe and the largest for the Italian segment.

\footnotetext{
${ }^{1}$ The International Capital Market Association has warned that the persistent lack of high-quality government bond collateral have started undermining repo trading (see discussion in the 17 October 2016 Financial Times' article: https://www.ft.com/content/1b6736cc-9232-11e6-8df8-d3778b55a923 (subscription required; last accessed on 8 May 2019).
} 
Regarding the first question on the specific intraday patterns in ON GC repo rates, two alternative hypotheses can be entertained based on the liquidity demand of banks. If banks perceive a high risk of not meeting their end-of-day liquidity needs or they want to be more cautious, they will try to secure a larger amount of funding earlier in the day. This greater demand may lead borrowing banks to pay a higher repo rate in the morning than in the afternoon (downward intraday pattern). ${ }^{2}$ Alternatively, if banks wait for the end of the day to offset liquidity unbalances via the ON GC repo market, then repo rates may be higher in the late afternoon when banks are more time constrained (upward intraday pattern). By looking at the intraday repo rate patterns we examine which liquidity management strategy prevails. Some existing papers have found evidence of downward intraday interest rate patterns in unsecured money markets: Furfine (2001) in the US Fedwire system; Bartolini, Gudell, Hilton and Schwarz (2005) in the Fed funds; and Baglioni and Monticini (2008, 2013) in the Italian e-MID trading platform. Jurgilas and Žikeš (2014) show that in the UK unsecured payment system (CHAPS) these patterns strengthened during the global financial crisis. With respect to GC repos, Kraenzlin and Nellen (2010) show intraday patterns in the Swiss franc ON repo market during the period January 1999-December 2009 and Abbassi, Fecht and Tischer (2017) in the German CCP-based repo rate (on Eurex) over the period January 2006 - June 2012.

Regarding the second question of which additional factors can determine the intraday variation of ON GC repo rates, we look at the characteristics of the collateral market. Our hypothesis is that if this market becomes riskier (i.e. bonds are on average less safe and less liquid) or more frictional (bonds are in lower supply), then intraday repo costs should increase and banks' intraday liquidity management could be badly affected. Abbassi, Fecht and Tischer (2017) show that the intraday repo rates are affected by lower liquidity in the repo market and greater funding uncertainty, particularly

\footnotetext{
${ }^{2}$ Also, because of the time value of money, intraday loans taken up in the morning - with longer duration - should require relatively higher interest rates (see Van Hoose, 1991; Angelini, 1998; Bech and Garratt, 2003, among others).
} 
during crisis periods, but do not control for the characteristics of the treasury collateral market. Our sample period covers the ESDC and the recent period of ECB unconventional monetary policy interventions, which have affected the liquidity and availability of Italian treasuries. These dramatic market conditions provide us with a unique opportunity to examine the relationship between repo rates and collateral characteristics because these variables present a wider range of values over the period considered.

The third question offers a direct cost comparison between centrally-cleared and bilaterally-traded ON GC repos and a study of how different factors affect the two market segments over different periods. This analysis is very important in light of the current debate on the effectiveness of CCPs' risk mitigation at the peak of regional and/or systemic crises and on the procyclical effects of higher margin policies. ${ }^{3}$ The global regulatory move towards derivatives central clearing warrants an examination of whether using CCPs (versus bilateral trading) in this specific repo market can effectively reduce counterparty risk and related costs at a time when this risk is high. To the best of our knowledge, this comparative analysis has never been addressed in previous studies. Boissel, Derrien, Ors and Thesmar (2017) show that for the GIIPS countries (Greece, Ireland, Italy, Portugal and Spain) daily ON GC CCP-based repo spreads react to higher country sovereign risk (proxied by sovereign credit default swap spreads) at the peak of the ESDC. Their study does not offer a direct comparison between $\mathrm{CCP}$ and bilaterally-traded repos and disregards any control for the characteristics of the treasury collateral market.

Finally, to the best of our knowledge, our paper is the first to provide a formal analysis of how repo borrowers select a particular instrument as collateral in ON GC repos and how their selection

\footnotetext{
${ }^{3}$ In a 2015 article for BIS Quarterly Review, Domanski, Gambacorta and Picillo claims that, while mitigating counterparty credit risk, central clearing may give rise to other forms of systemic risk. In particular, the concentration of the risk management of credit and liquidity risk in the CCP may affect system-wide market prices and liquidity dynamics in ways that are not yet understood. The CCP may buffer the system against relatively small shocks at the risk of potentially amplifying larger ones.
} 
criteria change depending on whether they trade in the CCP or bilateral segment, or in stressed/normal repo and collateral market conditions.

We provide several contributions. First, we show that the intraday repo spread, the difference between the repo rate for Italian ON GC repos and the daily ECB deposit rate, decreases steadily from the first hour of the trading day until market closure. We also show that the steepness of this downward pattern is higher during the ESDC. We conclude that the majority of borrowing banks behave cautiously and try to secure funding earlier in the day, especially in periods of higher funding stress. A less funding-constrained bank may benefit from this by strategically opting for accessing the ON GC repos at a lower cost just before the end of its business hours.

Second, we find that collateral availability and liquidity have a great impact on the Italian ON GC intraday repo spread also after controlling for repo net order flows, number of repo trades, repo volatility and the excess liquidity supplied by the ECB. The effect of some of these factors changes during and after the ESDC period. The collateral and repo factors, as well as the ECB excess liquidity, are all statistically-significant determinants during the crisis period. Their absolute impact is much reduced during the post-crisis period (i.e. after the ECB long-term refinancing operations (LTRO) in February 2012). We interpret these results as evidence that: i) ON GC repo lenders react efficiently to higher risk and frictions in the collateral and repo market by increasing the repo spread; and ii) ON GC repo lenders react to major ECB quantitative easing interventions that reduce the dependence of the intraday repo rate on the frictions and riskiness of the collateral market.

Third, we find that only when the CCP-based repos are no longer available the trading activity in bilateral repos increases, although bilateral trading on MTS is allowed throughout the day. In normal conditions, the CCP-based repo spread is on average lower than the bilateral repo spread, 
mostly due to CCP mitigation of counterparty credit risk. However, during the ESDC CCP-based repos are not significantly cheaper than the bilateral repo: higher margin costs increase the CCPbased repo spread generating a negative procyclical effect. Since the increased margins signal higher counterparty risk, they also affect the bilateral repo spread even if traders do not pay CCP margins to trade bilaterally. Higher bank/counterparty credit risk increases the repo costs for both the CCP and bilateral segment, particularly during the ESDC. This is a surprising result, given that the CCP should reduce the exposure of the repo contract to counterparty credit risk.

Finally, we find that bonds with lower bid-ask spreads (BASs), lower market supply and higher 'specialness' are less likely to be selected as collateral in ON GC repos. The difference between the GC repo rate and the special repo rate of a bond measures the bond specialness. ${ }^{4}$ Higher specialness signals greater market desirability or relatively scarcer supply of the specific collateral bond. According to Duffie (1996) model, more liquid bonds and bonds in lower supply are more desirable and more likely to be used in special repos. We see in our results that this type of bonds is less likely to be used in GC repos. Also, the higher the bond specialness, the cheaper its use in the special repo market, so the less likely it is that this bond would be used for GC repos.

Furthermore, we find a clear unintended impact of CCP margin policies on repo collateral selection. In periods of higher margin levels (such as the ESDC) the CCP-based repo borrowers are more likely to choose bonds with lower modified duration and higher liquidity, as they have a lower margin and help reducing the cost of repo central clearing. During the ESDC, the higher the margin to be paid for a specific collateral bond, the lower the probability that that bond is selected as collateral for CCP-based repos.

\footnotetext{
${ }^{4}$ While in an ON GC repo the borrower bank can specify the collateral bond after the repo trade is agreed (choosing amongst a pre-defined basket of bonds), in an ON special collateral repo the borrower bank must specify a unique bond to be used as collateral at the outset of a repo transaction paying a (generally) lower 'special' repo rate.
} 
The paper is organised as follows. Section 2 offers an introduction to the ON GC repo market and some preliminary statistics. Section 3 illustrates the intraday patterns in repo spreads. Section 4 and Section 5 presents respectively the study on the determinants of ON GC intraday repo spreads and on bond collateral selection. Section 6 summarises the findings, contributions, and implications of the paper.

\section{Overnight general collateral repos: Data selection and descriptive analysis}

A repo is a collateralised loan based on a simultaneous sale and forward agreement to repurchase a security at a future maturity date for its original value plus an interest rate for the use of the cash (the repo interest rate). The repo borrower borrows cash against a security used as collateral. The repo lender lends cash and then collects the repo interest rate. The 'first leg' of the ON GC repo contract (i.e. the sale of the collateral security) is instantaneously settled at the time of the trade, while the collateral is repurchased by the repo borrower on the next business day at around 7:00 a.m. Central European Time (CET). In GC repo transactions, the collateral can be any security from a predefined basket of securities and it is selected by the repo borrower shortly after the trade time. The maximum permitted time lag between the trade and the collateral selection is two hours. On the MTS, traders can opt for either CCP-based or bilateral ON GC repos. In CCP-based repos, a CCP becomes the credit provider for any repo borrower and the credit taker for any repo lender, so the contracts are theoretically not hindered by counterparty risk. Central clearance of Italian ON GC repos was introduced by the Cassa di Compensazione e Garanzia $(\mathrm{CC} \& \mathrm{G})$, the main Italian $\mathrm{CCP}$, on November 2, 2009. ${ }^{5}$ Since then, CCP-cleared transactions have become an increasing component of all ON repo transactions and reached $69 \%$ of the whole market by January 2012 and $95 \%$ by November 2015. In the CCP setting, banks do not know the identity of their counterparties. In

\footnotetext{
5 More information on Cassa di Compensazione e Garanzia (CC\&G) can be accessed via the following link: http://www.lseg.com/it/areas-expertise/post-trade-services/ccp-services/ccg/about-ccg-spa/ccg-history.
} 
bilateral repos counterparties instead know each other's identities. ON GC repos can trade from 7:45 a.m. until 3:30 p.m. (CET) with a maximum cut-off time for the selection of the collateral set at 3:45 p.m.

We analyse all ON GC repo contracts collateralised by all classes of bonds issued by the Italian Treasury: fixed coupon bonds (BTPs, Buoni del Tesoro Pluriennali); inflation-linked coupon bonds (BTIs, Buoni del Tesoro Pluriennali Indicizzati); treasury bills (BOTs, Buoni Ordinari del Tesoro); zero-coupon bonds (CTZs, i.e. Certificati del Tesoro Zero-Coupon); and floating notes (CCTs, Certificati di Credito del Tesoro).

We use the rich intraday MTS Time Series database for bonds and repos. Our sample covers the period from January 4, 2010, the first date available for intraday repo trades, until November 30, 2015. We concentrate on Italian sovereign GC repos because of the size and relevance of this market and because of the large number of available observations in MTS. The MTS repo platform is the leading market venue for trading GC repo contracts collateralised by Italian treasuries. MTS repo data provide intraday information on the transacted repo 'volumes' (i.e., the notional value of the repo contracts in euros corresponding also to the notional value of their collateral bonds), differentiated as borrower-initiated (repo) volumes and lender-initiated (reverse repo) volumes. In addition, MTS provide information on the total number of trades for each type of GC repo contract (CCP-based or bilateral) and for each bond used as collateral (identified by its unique ISIN code). For each business day, we collect all intraday ON GC Italian repo rates. ${ }^{6}$ We observe in total 77,467 intraday trades. The MTS bond data we use contain all intraday updates to the best three bid-quote and ask-quote levels (both prices and sizes). Moreover, for each collateral bond we have intraday

\footnotetext{
${ }^{6}$ We discard only two repos out of about 253,496 . These repos correspond to a bond that is not traded in the MTS secondary bond market during the sample period.
} 
prices and yields, intraday modified duration, ${ }^{7}$ and intraday trades. Other information about the specific characteristics of the instruments - e.g. issuance date, maturity date, coupon payment schedule etc. - are provided by MTS in separate bond reference files. Using the bonds' ISIN numbers, we match the repo market information with the bond market information. MTS does not provide trader identifications, for this reason we can only use information at the aggregate (market) level.

Panel A of Table 1 shows that during our sample period the total volume and the daily average volume of all ON Italian repo transactions executed on MTS are $€ 9$ trillion and $€ 6$ billion, respectively. Panel B of Table 1 shows that all bonds traded on MTS during the sample period are used at least once as collateral in ON GC repos. 335 different bonds are used as collateral for CCPbased repo contracts and 328 bonds for bilateral repos. Most of these bonds are short-term (179 out of 335), issued with one year or less to maturity (BOTs). The remaining collateral bonds are longterm bonds, mostly BTPs (99) with maturities ranging from 3 to 30 years.

\section{[Insert Table 1 about here]}

In Figure 1, Panel A we plot the daily volume-weighted average of the intraday repo rates for both CCP and bilateral repos, versus the daily ECB deposit and lending rates. In mid-2010, when the Greek sovereign debt crisis becomes more acute, the Italian ON GC repo rate increases up to 75 basis points (bps) above the ECB deposit rate. In the summer of 2011, when the sovereign debt crisis spreads to Italy and Spain the repo rate reaches a peak at 150 bps above the ECB deposit rate. In the first half of 2014, in a context of falling inflation and a downward revision of the growth

\footnotetext{
${ }^{7}$ In the original MTS dataset there are several missing observations for the modified duration. We have computed the modified durations for all the bonds with missing information.
} 
forecasts (see Dunne, Everett and Stuart, 2015), the GC repo rate increases again, up to 60 bps over the ECB deposit rate.

Figure 1, Panel B shows that the daily volumes of CCP-based ON GC repos are stable, ranging from $€ 4.03$ billion in January 2010 to $€ 4.15$ billion in November 2015 , while the volumes of bilateral ON GC repos progressively decrease from $€ 1.78$ billion in January 2010 to $€ 0.22$ billion in November 2015.

[Insert Figure 1 about here]

Next, we define intraday repo spread as the difference between the Italian ON GC repo rate for an intraday transaction on day $t$ and the daily interest rate set by the ECB for depositing liquidity at its facility on the same day $t$. We measure the intraday repo spread each time a repo trade is executed on MTS. This spread measures the additional cost of the GC repo over the risk-free ECB deposit rate. ${ }^{8}$ The theoretical motivation for this intraday repo spread is further explained in Section 4.

Following Baglioni and Monticini (2008), Kraenzlin and Nellen (2010) and Abbassi et al. (2017) we obtain a measure of hourly repo spread. Each day is divided into eight hourly time bands, denoted by $h=1,2, \ldots, 8$. The first band starts at 8:00 a.m. CET and the last at 3:00 p.m. CET. ${ }^{9}$ Let us define $k$ as the counter of all transactions, during hour $h$ on day $t$, with $k_{h, t}=1, \ldots, K_{h, t}$. The hourly repo spread is computed as the volume-weighted average of intraday repo spreads for all $K_{h, t}$ repo contracts traded during the corresponding hourly band $h$ on day $t$ :

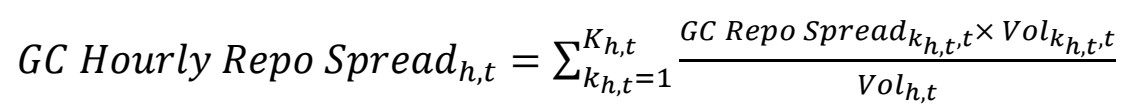

\footnotetext{
${ }^{8}$ Given the virtually-zero default probability of the ECB, the ECB deposit rate could be considered as the best approximation of a Euro area risk-free rate.

${ }^{9}$ We discard few trades before 8:00 a.m. and after 3:30 p.m. due to the limited number of observations available to obtain a meaningful hourly average for the intraday repo spread.
} 
For each hour $h$, we also create the repo spread for only CCP-based ON GC repos and the repo spread for only bilateral ON GC repos.

Table 2, Panel A shows some statistics on the number of repo trades used to construct these measures. The median values are nine CCP-based repo trades per hour and two bilateral repo trades per hour. The minimum value is one trade per hour. In Panel B, the number of repo trades is split by hourly-band. The number of CCP-based repo trades reaches its peak from 9:00 a.m. to 10:00 a.m. (15 trades per hour on average). The average number of trades in the bilateral segment ranges from 2.46 to 2.95 trades per hour in the afternoon, and from 1.41 to 1.98 in the morning hours. This preliminary evidence clearly shows that when building our measure of intraday repo spread we cannot take an interval smaller than one hour because at certain times of the day we have only one observation in a specific hourly-band.

[Insert Table 2 about here]

Figure 2 shows the total repo volumes (in billions of euros) traded in the two segments in each hour. Although bilateral repos can trade from 7:45 a.m. until 3:30 p.m. (CET), they are not frequently traded in the morning, while their trading activity is higher from 12:00 p.m. onwards.

[Insert Figure 2 about here]

Table 3 (Panels A, B and C) shows summary statistics for the hourly repo spreads for CCP and bilateral repos. The total number of hourly repo spread observations is 10,604. CCP-based repos have the largest number of observations $(5,980)$, while bilateral repos have 4,624 observations. Table 3, Panel A, shows that the CCP-based repo has an average hourly repo spread of 16.936 bps, almost 3 bps lower than the average hourly repo spread for bilateral repos. The hourly repo spread 
for CCP-based repos has a smaller standard deviation (20.053 bps) than the bilateral repo spread (23.400 bps). The proportion of observations with an hourly repo spread greater than 25 bps (see Table 3, Panel B) is $18.83 \%$ for CCP-based repos and $25.26 \%$ for bilateral repos, respectively. ${ }^{10}$

Table 3, Panel C shows average repo spreads by hourly band for CCP-based and bilateral repos over the ESDC period and the post-crisis period separately. We learn several interesting features from this table. First, we observe an intraday downward pattern (from 9:00 a.m. onwards) in the repo spread over the full sample period for both CCP-based repos and bilateral repos, although for the latter only over the more intense afternoon trading session. While the downward pattern is visible over the ESDC subsample, there is a less clear intraday pattern over the post-crisis subsample. This may reflect a more cautious and risk-averse intraday liquidity management strategy of banks during the crisis period. Second, we observe that the repo spreads for each hourly band are on average much higher during the ESDC period for both CCP-based and bilateral repos. This finding highlights the need to consider other factors driving the hourly repo spread, in addition to the time value of money and to the intraday liquidity management needs of banks. We hypothesise that the collateral's characteristics may have a great deal of impact to determine higher repo spreads during the peak of the crisis period. Third, when considering the full sample period, CCP-based repos appears always cheaper than bilateral repos for each hourly band (until the CCP-based repo trading ends) and their difference is also statistically significant. However, during the ESDC subsample CCP-based repos are no longer cheaper then bilateral repos. This preliminary evidence seems to cast doubts on the effectiveness of the $\mathrm{CCP}$ in mitigating counterparty risk during crisis periods. In the empirical analysis we test the impact of margin costs and banks/counterparties credit

\footnotetext{
${ }^{10}$ Extremely high values of intraday repo spreads are the result of high repo rates on particular trading days during the peak of the ESDC. Moreover, on specific days, dealers are willing to pay high repo rates in order to have access to funds that are scarce in the market, for instance when they are required to cover their regulatory liquidity needs at the end of the month or at the end of the reserve maintenance period.
} 
risk on repo spreads, after controlling for the hourly trading patterns and the collateral characteristics.

\section{[Insert Table 3 about here]}

The evidence reported in this section suggests that it is important to analyse repo spreads at the intraday level, separately for the CCP and bilateral segments, as well as for the ESDC and postcrisis periods. It also suggests the need to look at a wider set of impact factors that may explain why both CCP-based and bilateral repo costs have substantially increased over the ESDC period.

\section{Intraday patterns in repo spreads}

We start the econometric analysis by testing whether the intraday downward sloping pattern in the Italian ON GC repo spread observed in Section 2 is statistically significant.

We estimate the following model:

GC Hourly Repo Spread Sht $=c+\sum_{h=1}^{7} \alpha_{h} x_{h, t}+\lambda^{\prime} X_{t}+\sum_{h=1}^{7} \gamma_{h}^{\prime} X_{t} x_{h, t}+\partial C C P_{h, t}+\epsilon_{h, t}(2)$

where: $c$ denotes the fifth hourly band 12:00 p.m. $-1: 00$ p.m. (constant term); $h$ refers to seven different hourly bands (excluding the hourly band 12:00 p.m. $-1: 00$ p.m.) on day $t ; x_{h, t}$ is a dummy variable that takes a value of one if the repo contract is traded during the hourly band $h$, and zero otherwise; $\alpha_{h}$ reflects the difference between the average repo spread at 12:00 p.m. - 1:00 p.m. and the average repo spread in the time band $h$; and $\epsilon$ is the i.i.d error term. $X_{t}$ is a vector of dummy variables for seasonal effects (used also by Jurgilas and Žikeš, 2014; and Abbassi et al., 2017): end of reserve maintenance period, end of month, end of year, and day-of-the-week effects. By including $\lambda^{\prime} X_{t}$ in the equation, we allow the constant of the regression to vary with the seasonal 
effects. We also interact $X_{t}$ with the hourly dummies $x_{h, t}$. Finally, we also use a dummy $C C P$, which is equal to one when the average hourly repo spread refers to CCP-based repos, and zero otherwise. The coefficient $\partial$ captures the marginal difference between the average hourly spread of CCP-based repos and bilateral repos. We expect $\partial$ to be negative due to the reduction of counterparty credit risk by the CCP.

We first estimate model (2) for both CCP-based and bilateral repo contracts. Then we re-estimate it separately for CCP-based and bilateral repos (thereby dropping the $\mathrm{CCP}$ dummy). The results are reported in Table 4.

[Insert Table 4 about here]

For the sample of all repos (first column), we find that the hourly dummies are almost all significant at the $1 \%$ level, with decreasingly positive coefficients in the morning hours (from 9:00 a.m. to 12:00 p.m.) and increasingly negative coefficients in the afternoon hours (from 1:00 p.m. to 3:00 p.m.). Therefore, we observe a statistically significant downward sloping pattern in the intraday repo spread over the trading day, due to the incentive for banks to ensure funding liquidity at the beginning of the day (Angelini, 1998; Van Hoose, 1991) and to reduce the repo rate uncertainty. The repo spread increases slightly in the last hour, from 3:00 pm to 4:00 p.m. This is most probably due to the higher cost of immediacy during the last hour, after most trades have been already concluded. ${ }^{11}$ In Table 4 (first column) the coefficient of the CCP dummy is negative and highly significant, as expected.

\footnotetext{
${ }^{11}$ This explanation is supported by anecdotal evidence and discussion with an MTS repo trading expert.
} 
For the sample of CCP-based repos, we can only estimate the hourly dummies until the fifth hour of the trading day (12:00 pm - 1:00 p.m.), as this corresponds to the last hour of CCP-based repo trading on MTS. The repo spread peaks in the second hour of trading and then it gradually decreases over the trading day, therefore showing a downward sloping pattern. For bilateral repos, the morning hourly dummies (until 12:00 p.m.) are not significant, reflecting the low trading activity during this part of the trading day. Only the hourly dummies for the afternoon appear highly significant (at the $1 \%$ level) and increasingly negative.

Regarding the seasonal controls, in unreported results we observe that the end-of-month and the end-of-reserve-maintenance dummies carry positive and significant coefficients: repo spreads are higher at these times when banks tend to be more under pressure in their daily liquidity management (similar evidence is provided by Quiros and Mendizabal, 2006, and Jurgilas and Žikeš, 2014). The coefficients of the interaction terms between the end-of-year dummy and the time-ofday dummies are positive and significant in the morning hours of the trading day and negative in the afternoon hour from 2:00 to 3:00 pm, indicating a greater funding demand in the morning as the end of the year approaches. The coefficients for the days-of-the-week dummies (Monday, Tuesday, Thursday and Friday) are negative, but not statistically significant. Also their interactions with the time-of-the-day dummies are not statistically significant. Only if we exclude from the model the control for these interactions, the Friday dummy reports a negative and statistically significant coefficient. This may suggest a lower demand of funding at the end of the week, when the trading activity is lower than in other days, hence a lower repo spread. Finally, we notice that the estimated intraday patterns remain quantitatively similar when removing all these seasonal controls.

Lastly, in further unreported results we verify that the downward pattern in the intraday ON GC repo rate is also obtained: (i) using individual repo trades (tick-by-tick data, as in Abbassi et al., 
2017; Jurgilas and Žikeš, 2014); and (ii) using the difference between each intraday repo rate and its daily volume-weighted average as an alternative measure of intraday repo spread (as in Baglioni and Monticini, 2008; Kraenzlin and Nellen, 2010). ${ }^{12}$

\section{The determinants of the intraday repo spread}

In the previous section, we study only the intraday hourly patterns in repo spreads for both CCP and bilateral repos. The preliminary evidence in Section 2 suggests however that the intraday dynamics of repo spreads may be also affected by other factors and with different intensity during and after the ESDC. In this section, we first investigate the effects of collateral and repo market factors. Then we explore the impact of regulatory changes in margin policy. Finally, we look into the direct impact of counterparty risk. We perform the analysis on the full sample of repos, on CCP and bilateral repos separately, and on the ESDC and the post-crisis subsamples separately.

\subsection{Collateral and repo market factors}

We start by assuming, as in Boissel et al. (2017), that lenders can arbitrage between ON lending on the repo market at GC Repo Rate $_{h, t}$ (where $h$ indicates the hour of the repo transaction, $t$ the day)

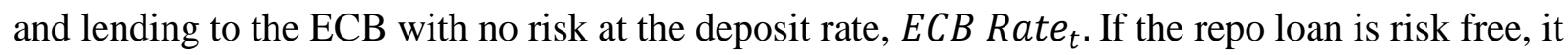
will be priced equal to the $E C B$ Rate $_{t}$. We conjecture that in the presence of frictions and risk in the

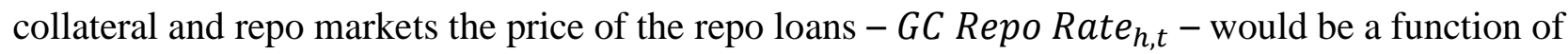
both collateral and repo factors, as they were observed in the previous hour $\left(X_{h-1, t}^{B O N D}\right.$ and $\left.X_{h-1, t}^{R E P O}\right)$. The expected GC repo rate is equal to the ECB rate plus the expected repo $\operatorname{spread} S\left(X_{k, t, h-1}^{B O N D}, X_{k, t, h-1}^{R E P O}\right)$ :

\footnotetext{
${ }_{12}$ All results that are unreported due to space constraints in the paper are available from the authors upon request.
} 
GC Hourly Repo Rate R $_{h}=E C B$ Rate $_{t}+S\left(X_{h-1, t}^{B O N D}, X_{h-1, t}^{R E P O}\right)$

We can re-write (3) as the following implicit regression model:

GC Hourly Repo Spread $h, t=\alpha+S\left(X_{h-1, t}^{B O N D}, X_{h-1, t}^{R E P O}\right)+\varepsilon_{i, h, t}$

Differently from all previous papers, we use a wide set of collateral characteristics $\left(X^{B O N D}\right)$ to explain variations of the intraday repo spread. Below, we list these factors and explain our hypotheses regarding their impact on the repo spread in terms of supply-demand or risk-return effects.

In the GC repo market, dealers have to price the repo before they know which security will be provided as collateral. Thus, we assume they price the repo based on the characteristics of a representative security in the collateral basket. More specifically, on each day $t$ we assume that they look at the average characteristics of a reference portfolio of bonds that have been selected as collateral in repo transactions over the previous trading month.

We start by controlling for the supply level of Italian government bonds in the secondary MTS market. A higher bond supply in the secondary market indicates that banks can access more bond notional and use it as collateral to borrow at the ON GC repo rate (instead of borrowing at the higher rates offered in the $\mathrm{ON}$ unsecured funding markets). Therefore, there can be higher demand of ON GC repos. As the demand for ON GC repos from borrowing banks increases, the repo spread increases too. When collateral supply is instead limited (i.e. there are supply frictions in the collateral market), the GC repo demand decreases and so does its intraday repo spread. We take for each bond the average notional on sale at the top three levels of the dealer's order book over each hour on each trading day. Then we build the cross-sectional average Bond Supply across all bonds 
in the reference portfolio, and separately for bonds used in CCP-based and for bilaterally-traded repos. Appendix A provides all details on the construction of Bond Supply. Figure 3 plots average Bond Supply against the total outstanding notional value of Italian government bonds available in the secondary market (measured in euros). Both variables show an increasing trend over time, but the average Bond Supply displays greater variability around this trend, therefore capturing better the change in traders' endowments of bonds in the secondary MTS market.

[Insert Figure 3 about here]

Next, we expect that the more liquid the bonds used as collateral, the lower the intraday repo spread: repo lenders receive good-quality safe collateral and the riskiness of the repo trade decreases. We use the relative bid-ask spread (Bond BAS) as proxy for bond liquidity. We take for each bond the average bid-ask spread over each hour on each trading day. Then we build the crosssectional average Bond BAS across all bonds in the reference portfolio, and separately for bonds used in CCP-based and for bilaterally-traded repos. Appendix A provides all details on the construction of Bond BAS.

Finally, with higher bond credit and interest rate risk that can reduce the value of the collateral, the repo lender requires a higher intraday repo rate as compensation. Bond credit risk is already captured by the quoted bid-ask spread. ${ }^{13}$ We use the bond modified duration based on the last observed price of the bond for each hourly band on each specific day as the measure of collateral interest rate risk. We expect that the higher the average modified duration of the bonds used as collateral, the higher the interest rate risk exposure of the bonds, the higher the intraday GC repo

\footnotetext{
13 Pelizzon, Subrahmanyam, Tomio and Uno (2016) show that the quoted bid-ask spreads of Italian treasuries are closely correlated with their credit risk, measured by the Italian CDS spread. As a consequence, controlling for other measures of sovereign risk would be redundant in this setting.
} 
interest rate. Supply, liquidity and modified duration of the collateral bonds are constructed using tick-by-tick intraday data from MTS and implementing a sequence of filtering steps described in Appendix B.

In addition to bond factors, we also consider supply-demand frictions and risk in the repo market. We control for the repo net order flow, i.e. the difference between aggregate volume of repos and aggregate volume of reverse repos for each hourly band, day and repo contract. We expect that a higher net order flow, indicating higher net demand pressure for GC repos, will lead to a wider repo spread. We also control for the number of trades in the repo market, for each day, hourly band and type of repo contract. An increase in the number of repo trades often happens when repo lending replaces riskier unsecured funding sources. In this case, repos work as a 'shock absorber' when funding risk is higher (Mancini, Ranaldo and Wrampelmeyer, 2016). This implies that a higher number of repo trades leads to a larger repo spread. Also, we control for repo volatility as a proxy for risk in the repo market. We measure it as the standard deviation of all repo rates for each hourly band computed over a 22-day rolling window. If the repo market is more volatile, the repo spread will be higher.

As a final control variable, we consider the excess liquidity injected in the system by ECB unconventional interventions. Consistent with the ECB definition, we compute daily excess liquidity as the sum of credit institutions' current account holdings and funds deposited at the ECB deposit facility minus their reserve requirements. ${ }^{14}$ A positive excess liquidity indicates a liquidity surplus in the financial system, which reduces the repo spread. Mancini et al. (2016) observe that the excess liquidity is inversely and nonlinearly related to the GC Pooling repo rate. When the repo rate hits the bottom of the ECB's interest rate corridor, i.e. the deposit rate, it will no longer be

\footnotetext{
${ }^{14}$ Data on ECB deposits and reserve requirements can be downloaded at the following link: http://www.ecb.europa.eu/stats/monetary/res/html/index.en.html.
} 
responsive to additional liquidity provision. On the contrary, additional provisions could even deteriorate the repo volumes and the marginal excess liquidity can become positively related to the repo rate. To allow for these non-linear effects we add the squared term of the ECB excess liquidity.

Table 5, Panels A, B and C report summary statistics for all the explanatory variables. The average collateral bond across the whole sample has a secondary-market supply of $€ 47$ million, a bid-ask spread of $26 \mathrm{bps}$ and around four years of modified duration. The difference between the average bond supply, bid-ask spread and modified duration of CCP-based and bilateral repos equal $€ 0.6$ million, 2 bps and -0.09 years respectively. Although these differences are not substantial in magnitude, in unreported results we observe that they are statistically significant. There is higher net selling pressure (negative order flows), higher number of trades and lower volatility in the CCP segment than in the bilateral one.

[Insert Table 5 about here]

In Table 6, Panels A, B and C, we check the sample correlations between all variables. We observe higher correlations only between Bond Supply and Bond BAS (-59\% for the whole sample, $-63 \%$ for CCP, $-53 \%$ for bilateral) and between Bond BAS and Repo Volatility (63\% for the whole sample, $60 \%$ for CCP, $70 \%$ for bilateral). We observe negative correlation between Bond Modified Duration and Excess Liquidity, ranging between $53 \%$ and 66\%, mostly recorded over the post-crisis period (from February 2012 to June 2014), when the excess liquidity gradually decreases from its high levels of the ESDC period, while the average bond modified duration gradually increases.

[Insert Table 6 about here] 


\subsection{Model specification}

We estimate the following model:

$$
\begin{aligned}
& \text { GC Hourly Repo Spread } \text { Sht }=\alpha+\beta_{1} \text { Bond Supply }_{h-1, t}+\beta_{2} \text { Bond BAS }_{h-1, t}+ \\
& \beta_{3} \text { Bond Mod.Duration }_{h-1, t}+\beta_{4} \text { Repo Net Order Flow } \text { Sl-1, }^{+} \\
& \beta_{5} \text { Repo Trades }_{h-1, t}+\beta_{6} \text { Repo Volatility }_{h-1, t}+\beta_{7} \text { CCP }_{h-1, t}+\beta_{8} E L_{t-1}+ \\
& \beta_{9} E L_{t-1}^{2}+\sum_{h=1}^{7} \alpha_{h} x_{h, t}+\lambda^{\prime} X_{t}+\sum_{h=1}^{7} \gamma^{\prime}{ }_{h} X_{t} x_{h, t}+\epsilon_{h, t}
\end{aligned}
$$

We use all lagged variables $(h-1)$ on the right-hand side of equation (5) to avoid endogeneity problems. All beta-coefficients, except the one of excess liquidity $\left(\beta_{8}\right)$, are expected to be positive.

As in model (2), we also control for time-of-day effects $\left(x_{h, t}\right)$ and for seasonal effects $\left(X_{t}\right)$ interacted with hourly dummies $x_{h, t}$. When we perform the regression on the aggregate sample of repos, we also include the $C C P$ dummy.

\subsection{Empirical results}

First, we estimate model (5) using pooled OLS with Newey-West HAC robust standard errors for both CCP and bilateral repos together. Then the same model (5) is estimated separately for CCPbased repos and bilateral repos. The results are reported in Table 7 for the 'All Repos' sample (columns 1 to 4), the 'CCP-based repos' subsample (columns 5 to 8) and the 'Bilateral repos' subsample (columns 9 to 12 ).

In order to account for the highly correlated regressors (Bond BAS and Bond Supply, Bond BAS and Repo Volatility, and Bond Modified Duration and Excess Liquidity), we start by introducing them sequentially. In the first specification (columns 1, 5, and 9) we include Bond Supply, Bond 
Modified Duration and Bond BAS and exclude any repo factor (so to avoid the high collinearity between Bond BAS and Repo Volatility). In the second specification (columns 2, 6 and 10) we include Bond BAS and exclude both Bond Supply and Repo Volatility. If we compare the two different specifications in columns 1 and 2, however, we notice only a small reduction in the estimated coefficients of Bond BAS and Bond Modified Duration (not in their level of statistical significance) when we use the more complete specification. In the third specification (columns 3, 7, and 11) we include Bond Supply and Repo Volatility and drop Bond BAS. If we examine the two different specifications in columns 2 and 3, we notice only a change in the estimated constant and in the magnitude of the Lag Repo Trades coefficient (not in its level of statistical significance). In the fourth specification (columns 4, 8 and 12), we keep Bond Supply, Bond BAS, and Repo Volatility and instead drop Bond Modified Duration to include a control for Excess Liquidity and its squared value. Although controlling for Repo Volatility and Excess Liquidity renders Bond BAS insignificant, this most complete specification of model (5) in columns 4, 8 and 12 explains almost half of intraday repo spread variation (about $48 \%, 50 \%$ and $46 \%$ for all repos, CCP-based repos and bilateral repos, respectively). We compute the variance inflation factor (VIF) for each of the correlated regressor used in this specification in order to mitigate concerns of multicollinearity. VIF (Mansfield \& Helms, 1982) measures whether the variance of the regressor coefficient is inflated due to high correlation with other regressors in the model. By rule of thumb, a VIF greater than 10 signals the presence of possible multicollinearity. Bond BAS, Bond Supply and Repo Volatility have VIFs of about 3, 2, and 2, respectively. This suggests that there is no clear indication that we should remove one of these regressors because of multicollinearity issues.

[Insert Table 7 about here] 
We start our discussion of the results from the collateral characteristics. As conjectured, the intraday repo spread increases significantly with higher Bond Supply. In economic terms, ${ }^{15}$ a one standard deviation increase in Bond Supply induces an increase in the intraday repo spread of $5.14 \mathrm{bps}, 3.07$ bps and $7.83 \mathrm{bps}$ for all repos, $\mathrm{CCP}$ and bilateral repos, respectively. Bond BAS is significant at the $1 \%$ level for all repos, CCP-based repos and bilaterally-traded repos with the hypothesised positive coefficient. The less liquid the bonds, the costlier it is to obtain repo funding. A one standard deviation increase in Bond BAS induces an increase of 6.15 bps (all repos), 5.47 bps (CCP-based repos) and $6.51 \mathrm{bps}$ (bilateral repos). Bond Modified Duration is significant at the $1 \%$ level with the expected positive sign. The higher the interest rate risk of the bonds, the higher the intraday repo spread demanded by repo traders. A one standard deviation change in Bond Modified Duration generates an increase of 4.13 bps (all repos), 2.25 bps (CCP-based repos) and 6.79 bps (bilateral repos) in the intraday repo spread, ceteris paribus.

Next, we consider the repo characteristics. Repo Net Order Flow displays the conjectured positive sign and it is significant at the $1 \%$ level. Greater repo net demand increases the intraday repo spread. The economic impact of Repo Net Order Flow on the intraday repo spread is of 1.57 bps (all repos), 1.97 bps (CCP-based repos) and 1.22 bps (bilateral repos) standard deviations. ${ }^{16}$ Repo trades have positive coefficients that are significant at the 5\% level for the aggregate repo sample and at the $1 \%$ level for CCP-based repos and bilaterally-traded repos. A one standard deviation change in Repo Trades induces an increase of 0.61 bps (all repos), 0.86 bps (CCP-based repos) and 1.44 bps (bilateral repos) in the intraday repo spread. Finally, Repo Volatility is also positively related to the intraday repo spread and its coefficients are highly significant at the $1 \%$ level. The higher the repo

\footnotetext{
15 The economic impact of an independent variable is calculated as the product between the standard deviation of that independent variable and the estimated coefficient (over the specific subsample considered). When calculating the economic impact of the collateral characteristics, we refer to their estimated coefficients in Table 7, column 1 (for the aggregate sample), 5 (for CCP-based repos) and 9 (for bilateral repos).

${ }^{16}$ We refer to Table 7, columns 4, 8 and 12 for the purpose of discussing the economic impact of the repo factors and excess liquidity on the intraday repo spread of the aggregate sample, CCP-based repos and bilateral repos, respectively.
} 
volatility, the higher the uncertainty in funding conditions, and the higher the intraday repo spread. Repo Volatility has a high economic impact on the intraday repo spread: a one standard deviation increase in Repo Volatility induces an increase of 7.59 bps (all repos), 6.97 bps (CCP-based repos) and 8.46 bps (bilateral repos) on the intraday repo spread.

Excess Liquidity (EL) is significant at the $1 \%$ level with the expected negative sign: the higher the excess liquidity, the lower the repo spread. However, the squared term of the EL is positive and statistically significant. We are interested in the overall economic impact of the EL: a one standard deviation change in EL generates a decrease of -7.02 bps (all repos), -6.88 bps (CCP-based repos) and -6.75 bps (bilateral repos) in the intraday repo spread as a cumulative impact, ceteris paribus.

Regarding the time-of-day effects, there is persistent evidence of a downward sloping pattern in the GC hourly repo spread. Since we control for more effects now, the estimated coefficients of the time-of-day dummies are smaller in size in Table 7 than in Table 4, however, they are still decreasing over the hours of the trading day and most of them remain statistically significant. Interestingly, when we add the control for Excess Liquidity (columns 4, 8, and 12 of Table 7) the impact of the time-of-day dummies on the GC hourly repo spread is drastically reduced. The excess liquidity available in the interbank market assuages the pressure for borrowing banks of not meeting their end-of-day liquidity needs on time. It is this specific pressure that pushes banks to behave cautiously and access extra overnight liquidity via the repo market in the earlier hours of the day generating the downward intraday pattern in the repo spread.

We observe that the dummy CCP has a significant negative coefficient in Table 7, columns 1,2 and 3. This indicates that on average CCP-based contracts have lower repo spreads than bilateral contracts, after controlling for all collateral and repo factors. However, in column 4, once we also 
control for the excess liquidity, the CCP dummy variable retains the negative sign, but it is no more statistically significant.

Next, we split the entire dataset into two sub-periods and re-estimate model (5) over each of them. The results are reported in Table 8 for the aggregate sample of repos (columns 1 to 4 ), for CCPbased repos (columns 5 to 8) and bilateral repos (columns 9 to 12). The first sub-period starts on January 4, 2010 and ends on February 10, 2012. This is the core period of the ESDC characterised by several ECB non-standard monetary policy interventions: (i) from May 10, 2010 until March 25, 2011 - the first activation period of the Securities Market Programme (SMP), involving the outright purchase by the ECB of government securities issued by Greece, Portugal and Ireland; (ii) from August 8, 2011 until February 10, 2012 - the second activation period of the SMP for Italian and Spanish government bonds; (iii) on December 21, 2011 - the start of the first three-year LTRO, granting secured loans with maturity of three years with an option of early repayment. The second sub-period, which runs from February 11, 2012 until November 30, 2015, is a relatively more tranquil post-crisis period, supported by further ECB interventions. ${ }^{17}$

In columns 2, 4, 6, 8, 10 and 12 of Table 8 we use the most complete specification of model (5) (i.e. the fourth specification used in Table 7) with Bond BAS, Bond Supply, Repo Volatility, and Excess Liquidity, but without Bond Modified Duration. In columns 1, 3, 5, 7, 9 and 11 we add a model specification excluding Bond BAS as possible source of multicollinearity to check whether there is any visible bias in the estimated coefficients of the remaining variables. The coefficients of the

\footnotetext{
17 On February 29, 2012 a second three-year LTRO is implemented by the ECB; while on July 26, 2012 Mr Mario Draghi, President of the ECB, announces his willingness to implement all possible measures ('Whatever it takes') to restore normal market conditions. On June 5, 2014, the ECB Governing Council announce the expanded asset purchase programme (EAPP) and two new four-year LTROs on September 18, 2014 and December 11, 2014. In addition, on September 4, 2014 the ECB main refinancing rate was lowered by $0.10 \%$ and two new purchase programmes started for both asset-backed securities and covered bonds issued by euro area financial institutions. On January 22, 2015 the ECB Governing Council announced the expansion of purchase programmes to the public sector starting on March 9, 2015 until November 30, 2015; see Dunne et al. (2015) for a detailed analysis.
} 
explanatory variables are all similar across the two different specifications and carry the same level of statistical significance.

In Table 8, we observe two main findings. First, the estimated coefficient of Bond Supply is positive in the crisis period, while negative and much smaller in magnitude in the post-crisis period. During the ESDC repo borrowers are under high funding stress. In the same period, the large initial purchase of Italian Government bonds by the ECB forcedly reduces the available supply of bonds in the secondary markets. With bond scarcity acting as a more binding constraint to the ability of doing repos, repo borrowers react more to any marginal increase in the available bond supply by demanding more GC repos and producing a rise in the repo spread. During the calmer post-crisis period, when repo borrowers are less funding-constrained and more adept at the ECB bond purchasing programme, Bond Supply has a much diminished impact on the repo spread. A higher Bond Supply may also act as a signal of calmer intervention by the ECB, generally driven by lower sovereign risk: so the cost of doing ON GC repos may even decrease.

Second, Bond BAS is significant over the ESDC period, but insignificant in the post-crisis period. Also, the repo factors and the excess liquidity have stronger economic impact on the repo spread during the ESDC. In the post-crisis period these factors still appear significant, but have a much lower impact.

[Insert Table 8 about here]

Overall, the sub-period results suggest that the ECB interventions and the high level of liquidity surplus provided by the ECB to the European financial system have contributed to reducing the influence of risk and frictions in the collateral and repo markets on the ON GC repo spread. 
For brevity Table 8 does not report the estimated coefficients of the hourly dummies, but Figure 4 shows that the intraday downward pattern in the repo spread is clearly defined only during the ESDC. In the post-crisis period, the pattern is almost flat for both CCP-based and bilateral repos. This finding confirms our hypothesis that it is mostly during stressed periods that banks opt for more cautious liquidity management and borrow more funds via repos in the morning.

\section{[Insert Figure 4 about here]}

Finally, in Table 8 we observe that the CCP dummy is insignificant in the sub-sample analysis. Although CCP-based repos should provide mitigation of counterparty credit risk, especially during the ESDC they behave rather like bilateral repos and are affected by the same factors. This result shows that the use of CCPs is not enough to prevent the repo traders from reacting to increasing sovereign and funding stress. We now look further into this point by examining the effect of changes in CCP margin costs.

\section{4. $\quad$ Changes in margin costs}

Margins are the preferred instrument adopted by the CCPs to mitigate the impact of counterparty risk in repos. During the period considered in our study, there have been important changes in the margin policies set by the CCPs. For instance, on November 8, 2011, at the peak of the Italian sovereign debt crisis, the CCP increases the margins required for Italian repos as a reaction to the deterioration of the creditworthiness of the Italian government guarantees. The margin increase ranges from 350 bps for bonds with duration of less than one year to 500 bps points for bonds with duration of more than seven years.

The International Monetary Fund, the Bank of Italy, and the European Union have criticised the margin policies adopted during the ESDC as being responsible for a further deterioration in funding 
costs and a possible negative procyclical effect. The theoretical model by Brunnermeier and Pedersen (2009) supports these considerations. Here we examine the alleged procyclical behaviour of the CCP margin policies in the Italian ON GC repo market. If margins are endogenous - i.e. they simply reflect the higher riskiness of the collateral - then they should not appear significant when added to the right-hand side of equation (5), where we already control for higher bond riskiness. If instead the margin increases are procyclical, then we expect that higher margin costs will have a further positive and significant effect on the ON GC intraday repo spread.

Table 9 illustrates the results of this check. We observe that higher margin costs during the crisis period further deteriorates repo funding conditions (a negative procyclical effect); while, in the post-crisis period, margin costs do not significantly impact the intraday repo spread. Margins have been changed by the CCPs also over the post-crisis period. However, in this case, the more favourable funding conditions - e.g. high excess liquidity in the European banking system - may have alleviated their potential negative procyclical effect on the intraday repo spread.

[Insert Table 9 about here]

In addition, in columns 1 to 6 of Table 9 we notice that the CCP dummy and the interaction term between margin costs and CCP dummy (measuring the differential impact of margin costs on CCPbased/bilateral repos) are not statistically significant. The CCP-based repos are not significantly cheaper than the bilateral repos.

We see that during the ESDC margin costs are significant for both CCP-based and bilateral repos, but the impact on the CCP-based repos is higher: a one standard deviation change in margin costs generates an increase of 9.79 bps (all repos), 11.08 bps (CCP-based repos) and 8.31 bps (bilateral repos) in the intraday repo spread (Table 9, columns 2, 8 and 12). The economic impact of changes 
in margin costs is almost null in the post-crisis period (Table 9, columns 5, 10 and 14). Although margin costs are borne only by traders who do repos via the CCP, they are significant also for bilateral repos because: i) they lead to negative procyclical effects; and ii) signal higher counterparty credit risk, therefore traders on the bilateral segment will protect themselves by increasing the cost of the repo. In the next sub-section we investigate this latter point.

\subsection{Counterparty risk}

We now check how bilaterally-traded and CCP-based repo spreads vary with the counterparty credit risk of Italian banks, computed as the difference between the daily CDS mid-quote for the Italian banking sector ${ }^{18}$ and the sovereign CDS mid-quote for Italy (Excess Bank CDS). The results are presented in Appendix C - Table C.1.

In Table C.1 we see that higher credit risk of the banks-counterparties increases the repo costs for both the CCP and bilateral segment, particularly during the ESDC. The interaction term between Excess Banks' CDS premium and CCP dummy (measuring the differential impact of counterparty risk on the CCP/bilateral segment) is not statistically significant. Furthermore, during the ESDC the economic impact of counterparty risk is higher for the CCP than for the bilateral repos: a one standard deviation change in the Excess Bank CDS generates an increase of 5.02 bps in the CCPbased repo spread and 4.32 bps in the bilateral repo spread (Table C.1, columns 2, 8 and 12). This is a surprising result, given that the CCP should reduce the exposure of the repo contract to counterparty risk.

We also control separately for the excess CDS premium of larger and smaller Italian banks (by market capitalisation) and observe that although larger banks are considered in general 'safer' than

\footnotetext{
${ }^{18}$ To understand the importance of banks as counterparties in the repo sector, MTS repo specialists have confirmed that more than $60 \%$ of volume of ON GC repo is traded by Italian banks. Data for CDS mid-quotes are sourced from Bloomberg.
} 
smaller banks, their credit risk impact on the repo cost is higher because larger banks are more active counterparties in repo contracts, given their reputation and their wider network of contacts in the repo business. The results of this check are also reported in Appendix C (Tables C.2 and C.3).

We perform several robustness checks on the main results of this section and report them all in Appendix D.

\section{Collateral selection for GC repos}

In this section, we assess how repo traders choose the collateral bond.

The tested hypotheses are the following:

(i) The larger the availability of a bond, the higher its probability of being selected as collateral;

(ii) The higher the bond riskiness (so the higher its bid-ask spread and its modified duration), the more likely it is for traders to select the bond as collateral for the GC repo.

If having optionality, borrowing banks prefer using riskier and more illiquid bonds as collateral in GC repos in order to keep safer and more liquid bonds 'unencumbered' for regulatory purposes, for management of unexpected liquidity needs, or for use as collateral in special repos. According to Duffie (1996) model, liquid bonds are more likely to be used in special repos where the borrower specifies a unique bond as collateral at the outset of a repo transaction and pays a (generally) lower rate than the GC repo rate. We expect liquid bonds to be more likely used in special repos and less likely used in GC repos.

(iii) The higher the specialness of the bond, the cheaper its use in the special repo market, so the less likely it is for the bond to be chosen as collateral in GC repos. 
We estimate the following logit model:

P Prob. of Selection ${ }_{i, t}$

$$
\begin{aligned}
& =\alpha+\beta_{1} \text { Bond Outstanding Amount }_{\mathrm{i}, \mathrm{t}-1}+\beta_{2} \text { Bond BAS }_{\mathrm{i}, \mathrm{t}-1} \\
& +\beta_{3} \text { Bond Mod. Duration }_{\mathrm{i}, \mathrm{t}-1}+\beta_{4} \text { Bond Mod. Duration }_{\mathrm{i}, \mathrm{t}-1}^{2} \\
& +\beta_{5} \text { Bond Specialness } \mathrm{i}_{\mathrm{i}, \mathrm{t}-1}+\gamma^{\prime} \mathrm{X}_{\mathrm{t}}+\epsilon_{\mathrm{i}, \mathrm{t}}
\end{aligned}
$$

where $i$ indicates the bond and $t$ the day. The dependent variable in equation (6) is a binary variable that takes the value of one if the bond is selected at least once as collateral in a repo trade on day $t$ and zero otherwise. ${ }^{19}$ The explanatory variables are: the bond total outstanding notional amount, ${ }^{20}$ the bond bid-ask spread, the bond modified duration and its squared term, and the bond specialness measured as the difference between the GC rate and the bond special repo rate. ${ }^{21}$ All explanatory variables in equation (6) are bond-specific, computed at a daily frequency, and lagged by one day. ${ }^{22}$ We estimate the logit model with HC robust standard errors and bond fixed effects ${ }^{23}$ first for the whole sample of repos, then separately for CCP-based repos and bilaterally-traded repos, and over the ESDC and post-crisis periods. All results are reported in Table 10.

\section{[Insert Table 10 about here]}

\footnotetext{
${ }^{19}$ We have also employed two alternative measures for the dependent variable. The first measure is computed as the ratio between the daily nominal transacted volume for each bond collateral and the nominal transacted volume for the all collateral bonds used on the same day. The second measure is the ratio between the daily transacted quantities of each bond collateral (calculated as daily nominal transacted volume for the bond collateral divided by its daily price) and the daily aggregate transacted quantities of all collateral bonds used on the same day. These measures indicate how many times a bond is chosen as collateral on day $t$. Results are qualitatively similar. Correlations between the explanatory variables are the following: $11 \%$ between Bond Outstanding Amount and Bond BAS, 35\% between Bond Outstanding Amount and Bond Modified Duration, 2\% between Specialness and Bond Outstanding Amount, $27 \%$ between Margin Costs and Bond Outstanding Amount, 50\% between Bond BAS and Bond Modified Duration, 5\% between Bond BAS and Specialness, 43\% between Bond BAS and Margin Costs, 5\% between Bond Modified Duration and Specialness, 74\% between Bond Modified Duration and Margin Costs (never included together as explanatory variables), and 32\% between Margin Costs and Specialness.

${ }^{20}$ The outstanding amount of bonds is calculated from data on auctions conducted in the primary market by the Bank of Italy in collaboration with the Italian Treasury. See the following links: http://www.dt.tesoro.it/en/debito_pubblico, http://www.bancaditalia.it/.

${ }^{21}$ We use 'tomorrow next' (TN) GC and special repos, since TN repos are the most frequently traded special repos in MTS.

${ }^{22}$ The model has been estimated also at intraday frequency and results are robust.

${ }^{23}$ Since some bonds may be transacted more on special than others, especially if they have been targeted for particular trading strategies, we need to control for bond fixed effects. Also F-tests and Hausman (1978) tests confirm the need to control for bond fixed effects, but not for random effects.
} 
Looking at the full sample (Table 10, column 1), all explanatory variables are highly significant at the $1 \%$ level and with the expected signs of coefficients. Ceteris paribus, every additional $€ 3$ billion of notional issued by the Italian Treasury (average size of an auction) increases the probability for the bond to be chosen on average by $1.56 \%$. If the bid-ask spread increases by $1 \mathrm{bp}$, the marginal probability increases by $0.04 \%$. A large increase in the Bond BAS of 250 bps during the crisis could trigger an increase in the marginal probability of $10 \%$ on average. For every additional year of modified duration, the probability increases in total by $1.095 \% .{ }^{24}$ Finally, for every additional 1 bp of specialness, the probability decreases by $0.16 \%$. To understand the economic significance of this latter variable, we need to bear in mind that the bond specialness reached a peak of more than 100 bps for 10-year BTPs during the ESDC (see Dufour, Marra, Sangiorgi, and Skinner, 2019). Although the variables' marginal impacts look small in absolute terms, we must consider that the first criterion for a borrowing bank to choose a bond as collateral for the repo is to hold it in its portfolio. Even though borrowing banks have limited optionality, our results show that they will exercise it rationally.

Looking at the CCP-based and bilateral repos in Table 10, columns 2 and 7, we see that the bond modified duration for CCP-based repos appears with a negative coefficient: the lower the bond modified duration, the higher the bond's probability of being selected as collateral for CCP-based repos. This sign inversion may be related to the higher margins set by the $\mathrm{CCP}$ for longer maturity collateral, which increase the cost of repo trading. Therefore, a borrowing bank may be incentivised to reduce the margin costs by selecting shorter-maturity collateral for the CCP-based repo. In addition, we see that the bond outstanding amount carries a negative sign for bilateral repos and a positive sign for CCP-based repos. Taken together, these results suggest that longer maturity bonds

\footnotetext{
${ }^{24}$ This total marginal probability for Bond Modified Duration includes both the effects from the linear term and the quadratic term.
} 
with higher modified duration and relatively lower outstanding amount are mostly used for bilateral repo trading where there are no specific margin requirements, while bonds with relatively shorter durations and in higher supply are chosen more often as collateral in the CCP-based repos to lower the margin costs.

We also explore whether the impact of these factors on the probability of collateral selection changes over time (see Table 10, columns 3, 5, 8 and 10). We use the same two sub-periods of the previous analysis in Section 4. The Bond Modified Duration has a positive effect for bilateral repos in both subsamples. Instead, for the CCP segment a negative sign is detected during the crisis period, when shorter duration bonds are preferred as collateral to longer duration bonds (the opposite is true after the crisis). We also observe a negative coefficient for Bond BAS for the CCP segment over the crisis subsample. Thus, during the ESDC period borrowers prefer using more liquid and shorter-maturity collateral in ON GC repos in order to avoid paying higher margins at the CCP. After the crisis, longer-maturity risky bonds are again those with a higher probability of being chosen as collateral for a CCP-based repo, despite this increasing the costs of using the CCP.

Next, we control directly for CCP margin costs. When margin costs are used as explanatory variables the Bond Modified Duration is dropped as they have $74 \%$ correlation. The results are reported in Table 10 at columns 4, 6, 9 and 11 and show that during the ESDC the higher the margin that needs to be paid for a specific collateral bond, the lower the probability that that bond is selected as collateral for CCP-based repos. Margin costs are instead insignificant to explain the choice of collateral in bilateral repos. Also, for bilateral repos the Bond BAS relates negatively to the probability that a bond will be selected as collateral during the ESDC period. Given that these repos do not offer any protection against counterparty risk, more liquid collateral is preferred in order to reduce the risk of not being able to liquidate the collateral in case one's counterparty fails 
to return the borrowed funds. In the post-crisis period, when the pressure from the collateral market decreases, the Bond BAS presents a positive coefficient: traders in the bilateral segment continue preferring to use riskier, more illiquid bonds as collateral and to keep more liquid bonds 'unencumbered' for regulatory purposes and management of unexpected liquidity needs.

\section{Summary and implications of the results}

In this paper, we study the dynamics and determinants of intraday ON GC repos on Italian Government bonds and the criteria behind repo borrowers' collateral selection. The ON GC repo is the main instrument used by banks for their intraday liquidity management, so any temporary shift or structural change in the ON GC repo market or in the collateral market can greatly affect these financial institutions. We use a rich intraday dataset of Italian repos and collateral bonds over the period from January 2010 to November 2015.

In the paper's introduction we asked four questions. First, we asked whether there is any intraday pattern in the ON GC intraday repo spread (over the ECB deposit rate). We find a downward sloping pattern. Due to the incentive of Italian banks to ensure funding liquidity at the beginning of the day, the repo spread is higher in the second hour of the trading day; then it tends to decrease steadily until closure. This pattern is accentuated during the ESDC period, due to a more risk-averse behaviour of the banks in their liquidity management.

Second, we asked which factors affect the ON GC intraday repo spread and whether their impact changes over time. We find that bond supply, liquidity and modified duration explain part of the variation of the intraday repo spread. The subsample analysis reveals, however, that their absolute impact is much higher during the ESDC period than during the post-crisis period. We interpret this result as evidence that the ECB quantitative easing interventions were highly effective in reducing 
the influence of the collateral market conditions on the repo spread. In addition to that, higher ECB liquidity injections in the banking system help reducing the ON GC repo spread. Taken together, our results unveil the important impact of ECB policies on sovereign repo markets.

Third, we asked whether there is any significant difference between ON GC repos cleared by a CCP and those traded bilaterally. We notice that the bulk of the bilateral trading starts when CCP trading stops (at 12:30 p.m.). Due to the mitigation of counterparty credit risk, the CCP-based repo spread is on average lower than the bilateral repo spread. However, during the ESDC we observe a lack of cost-differentiation between the two market segments. Increased margin costs during the ESDC period deteriorate repo funding conditions by increasing the repo spread and creating a negative procyclical effect. Although margin costs are incremented by the CCPs also over the post-crisis period, the more favourable funding conditions then (e.g. high excess liquidity in the European banking system) may have alleviated their potential negative procyclical effect on the intraday repo spread. Interestingly, we see that since higher margins signal higher counterparty risk, they have an indirect impact also on the bilateral repo spread, even if traders do not pay CCP margins to trade bilaterally. To prove this point, we show that the higher credit risk of the banks-counterparties increases repo costs for both the CCP and bilateral segments, particularly during the ESDC. This is a surprising result, given that the CCP should reduce the exposure of the repo contract to counterparty risk.

Finally, we asked which bond characteristics determine the probability of selection of a particular government security to be used as collateral in Italian GC repos. We find that bonds with lower liquidity, greater market supply and higher modified duration are more likely to be selected as collateral in GC repos. We also show that bonds with higher specialness are less likely to be used for GC repos as they can be more cheaply used to raise funds in the special repo segment. However, 
during the ESDC, we see that CCP-repo borrowers are more likely to choose bonds with lower modified duration and higher liquidity. The higher level of margins imposed by the CCP in this period incentivises borrowers to select higher-quality and more liquid collateral in order to reduce CCP-based repo costs. We find that during the ESDC the higher the margin that needs to be paid for a specific collateral bond, the lower the probability that the bond is selected as collateral for CCPbased repos. These results reveal a clear impact of CCP margin policies on repo collateral selection.

The main implications of the paper are the following:

1) It is important for banks that routinely use ON GC repos for their daily liquidity management to strategically decide the time of the day when to trade a repo contract. Our evidence shows that, particularly in periods of high systematic-funding stress, ON GC repo spreads are higher at the start than at the end of the day. Therefore, a less funding-constrained bank may decide to 'wait longer' and access this ON secured cash at a lower cost just before the end of its business hours.

2) The ON GC repo market responds efficiently to increased risks coming from the collateral bond market (increasing repo spreads), as well as to Central Bank interventions aimed at reducing the impact of such risks.

3) The regulatory call for more central clearance in the repo market must be assessed against the evidence on the effectiveness of CCPs in reducing counterparty risk and its associated costs and on the implications of changes in margin policy. Our paper shows that the mechanism of mitigation of counterparty risk does not prevent CCP-based repo spreads from increasing with higher risk in the collateral market, albeit at a lower extent than bilateral repos. In periods of high stress CCP-based repo spreads are not always lower than bilateral spreads and this is mainly due to the increase in margin costs. The higher margin costs can produce negative pro-cyclical effects and distortions in 
the collateral selection process of the borrowing banks. In other words, CCPs may introduce more frictions into the repo market.

The analysis of this paper is based on the Italian repo market. This specific market serves as a good example of the consequences of higher sovereign risk and resulting frictions on the secondary government bond market (illiquidity, higher margins, etc.). Any country that suffers at some point from the same conditions has the potential to see those risks and frictions transferred onto the ON GC repo market with a dangerous impact on banks' liquidity management. This could be the case for the other so-called GIIPS countries during the ESDC. 


\section{APPENDICES}

\section{Appendix A. Construction of bond bid-ask spread and bond supply}

The methodology of construction of these variables follows Darbha and Dufour (2013).

\section{A.1. Bond bid-ask spread}

First, the hourly Bond BAS for each bond is constructed as follows.

For each bond $i$, we calculate the intraday bid-ask spread related to a specific quote $j$ as:

$\frac{A s k_{i, j}-B i d_{i, j}}{\left(B i d_{i, j}+A s k_{i, j}\right) / 2}$. Ask and Bid are the ask and bid prices respectively. We assign to each of these intraday bid-ask spreads a weight equal to the portion of trading hour when quote $j$ remains available in the market before the next quote update. Then, we compute the hourly BAS as a timeweighted average:

${\text { Bond } B A S_{i, h, t}}_{i=1}^{Q_{h, t}}\left[\frac{\text { Ask }_{i, j}-\text { Bid }_{i, j}}{\left(\operatorname{Bid}_{i, j}+\text { Ask }_{i, j}\right) / 2}\right] x\left(\frac{T_{i, j+1}-T_{i, j}}{\text { Total Time }_{h, t}}\right)$

$t$ indicates a specific day and $h=1,2, \ldots, 8$ an hourly band. $T$ is the time stamp for the $\mathrm{j}^{\text {th }}$ quote update measured in seconds from midnight, $\left(T_{i, j+1}-T_{i, j}\right)$ is the length of time during which quote $j$ remains available before being updated, Total Time is the overall time in seconds that quotes are available for the hourly band $h$ on day $t$ (i.e. the time elapsing from the first proposal during the hourly band $h$ on day $t$ to the end of that hourly band), and $Q_{h, t}$ is the total number of quotes updates for the hourly band $h$ on day $t$.

Second, we build a weighted-average bid-ask spread across all bonds (as portfolio-weighted averages), and separately for bonds used in CCP-based repos and in bilaterally-traded repos for 
each hourly band of each trading day. The portfolio weights on day $t$ are calculated as the ratio between the quantity of each bond used as collateral and the total quantity of transacted collateral over the previous month (i.e. the previous 22 days starting from the day $t-1$ ).

We include in our 'portfolio' only bonds that have been actually used as collateral in the previous 22 days (or one month of trading), rather than including all available bonds, in order to capture better the average characteristics of the collateral. As over some days/weeks, repo trade volumes are small and only a limited number of bonds are used as collateral, we use 22 days as our time window. We assume that repo traders manage their baskets of collateral as portfolios from which to choose the bonds to be delivered in GC repos. We also apply portfolio daily rebalancing in order to capture variations in the collateral characteristics.

\section{A.2. Bond supply}

First, the hourly Bond Supply for each bond is constructed as follows.

For a given bond $i$, MTS reports the top three ask quotes at which dealers are prepared to sell bonds, with the relative bond notional amounts.

For each specific ask quote $j$ for bond $i$ during hour $h$, we calculate the supply for bond $i$ as the sum of these notional amounts. This represents the total amount of bond notional available for sale in the order book at the top three levels of the dealers' ask price.

Every time a new quote $j$ comes in, the bond's order book is updated, so the resulting top three levels of the ask price change and the sum of the notional amounts associated to these quotes (Bond Supply $i, j$ ) changes too. 
Then we calculate the hourly Bond Supply as the time-weighted average of all Bond Supply ${ }_{i, j}$ within a given hour:

Bond Supply $_{i, h, t}=\sum_{j=1}^{Q_{h, t}}$ Bond Supply $_{i, j} x\left(\frac{T_{i, j+1}-T_{i, j}}{\text { Total Time }_{h, t}}\right)$

where $t$ indicates a specific day, and $h=1,2, \ldots, 8$ a hourly band.

$T_{i, j}$ is the time stamp for quote $j$ (measured in seconds from midnight). Bond Supply ${ }_{i, j}$ is multiplied by the length of time during which quote $j$ remains available before being updated $\left(T_{i, j+1}-T_{i, j}\right)$ over the Total Time. Total Time is the overall time in seconds that quotes are available for the hourly band $h$ on day $t$ (i.e. the time elapsing from the first proposal during the hourly band $h$ on day $t$ to the end of that hourly band). $Q_{h, t}$ is the total number of quotes updates for the hourly band $h$ on day $t$.

Second, we build a weighted-average bond supply across all bonds (as portfolio-weighted averages), and separately for bonds used in CCP-based repos and in bilaterally-traded repos for each hourly band of each trading day in the same way we have explained it for the bid-ask spread. The portfolio weights on day $t$ are calculated as the ratio between the quantity of each bond used as collateral and the total quantity of transacted collateral over the previous month (i.e. the previous 22 days starting from the day $t-1)$. 


\section{Appendix B. Filtering steps for bond data}

In our study, we examine the relationship between the ON GC intraday repo spread and the intraday liquidity, modified duration and supply of the collateral bonds. These bond variables are constructed using tick-by-tick intraday data from MTS and implementing the same sequence of steps as in Dufour et al. (2019):

- We consider only bond quotes recorded during the regular daily trading hours from 8:15 a.m. until 5:00 p.m. CET and discard the last 30 minutes of the trading day.

- In order to account for latency issues, we assign the same time stamp to quotes submitted to parallel platforms - MTS and Euro MTS - when they have the same price and are recorded with a small time delay of up to 3 milliseconds.

- We construct the consolidated order-book using both MTS and Euro MTS quotes and compute the overall best bid and ask prices.

- We discard consolidated quotes with negative bid-ask spreads. These may appear when the best quotes on the two alternative platforms diverge temporarily.

- We discard quotes with extremely high bid-ask spreads, since trade execution is unlikely to take place when bid-ask spreads are so large. On MTS, dealers with market-making obligations cannot remove their quotes, but they are allowed to temporarily increase the spread to signal that they are not active. Short periods of unreasonably high bid-ask spreads are often the result of dealers increasing simultaneously their ask quotes and/or reducing their bid quotes. No trades are executed at these extreme quote levels. Therefore, we determine a maximum tradable spread level by conducting an ad-hoc analysis of the distributions over time of the relative bid-ask spreads observed in the consolidated order books before trade executions. We winsorise proposals with relative bid-ask spreads greater than the $99^{\text {th }}$ percentile of the distributions, for every maturity 
bucket, quarter and instrument class. This technique ensures that no extreme bias from periods of low trading intensity during the day (e.g. from 8:15 a.m. to 9:00 a.m.), as well as from times of exceptional circumstances, can alter our results. 
Appendix C. The effect of counterparty risk on repo spreads

\section{Table C.1: Counterparty risk - pooled regression results for model (5) over two sub-periods}

This table reports the regression results for model (5) of pooled OLS regression results over two sub-periods. European sovereign debt crisis (ESDC) sub-period: January 4, 2010 to February 10, 2012. Post-crisis period: February 11, 2012 to November 30, 2015. Pooled regressions are estimated with HAC robust standard errors. The dependent variable is the GC Hourly Repo Spread. Excess Bank CDS = CDS mid-quote for the Italian banking sector (calculated as the weighted average of CDS mid-quotes for Italian banks, with weights equal to their relative average market capitalisation over a 22-day rolling window) minus sovereign CDS mid-quote for Italy. Other variables' definitions and measurements are explained Table 5. Repo Net Order Flow is measured here in billions of euros. $\mathrm{EL}^{2}$ is rescaled over 1,000 . T-statistics are reported in brackets. $* * *$ indicates $1 \%$; $* * 5$; and $* 10 \%$ significance level, respectively.

\begin{tabular}{|c|c|c|c|c|c|c|c|c|c|c|c|c|c|c|}
\hline \multirow[b]{2}{*}{ Period } & \multicolumn{6}{|c|}{ All Repos } & \multicolumn{4}{|c|}{ CCP-based Repos } & \multicolumn{4}{|c|}{ Bilateral Repos } \\
\hline & \multicolumn{3}{|c|}{ ESDC } & \multicolumn{3}{|c|}{ Post-Crisis } & \multicolumn{2}{|c|}{ ESDC } & \multicolumn{2}{|c|}{ Post-Crisis } & \multicolumn{2}{|c|}{ ESDC } & \multicolumn{2}{|c|}{ Post-Crisis } \\
\hline & (1) & (2) & (3) & (4) & (5) & (6) & (7) & (8) & (9) & (10) & (11) & (12) & (13) & (14) \\
\hline Constant & $\begin{array}{l}-0.082 \\
(-0.02)\end{array}$ & $\begin{array}{l}4.335 \\
(1.04)\end{array}$ & $\begin{array}{l}4.338 \\
(1.04)\end{array}$ & $\begin{array}{c}27.928 \text { **** } \\
(18.83)\end{array}$ & $\begin{array}{c}27.024 * * * \\
(17.41)\end{array}$ & $\begin{array}{c}27.301 * * * * \\
(16.87)\end{array}$ & $\begin{array}{l}1.797 \\
(0.41)\end{array}$ & $\begin{array}{l}5.886 \\
(1.21)\end{array}$ & $\begin{array}{c}25.733^{* * * * *} \\
(13.16)\end{array}$ & $\begin{array}{c}25.033^{* * * *} \\
(12.34)\end{array}$ & $\begin{array}{l}0.071 \\
(0.01)\end{array}$ & $\begin{array}{l}4.078 \\
(0.63)\end{array}$ & $\begin{array}{c}28.908^{* * * *} \\
(14.22)\end{array}$ & $\begin{array}{c}28.270^{* * *} \\
(13.10)\end{array}$ \\
\hline Lag Bond Supply & $\begin{array}{c}0.545^{* * * *} \\
(8.58)\end{array}$ & $\begin{array}{c}0.441 * * * \\
(6.02)\end{array}$ & $\begin{array}{c}0.441 * * * \\
(6.02)\end{array}$ & $\begin{array}{c}-0.066^{* * * *} \\
(-4.61)\end{array}$ & $\begin{array}{c}-0.046^{* * * *} \\
(-2.86)\end{array}$ & $\begin{array}{c}-0.047 * * * \\
(-2.90)\end{array}$ & $\begin{array}{c}0.534 * * * \\
(6.44)\end{array}$ & $\begin{array}{c}0.431 * * * \\
(4.58)\end{array}$ & $\begin{array}{c}-0.055^{* * *} \\
(-2.65)\end{array}$ & $\begin{array}{l}-0.035 \\
(-1.54)\end{array}$ & $\begin{array}{c}0.552 * * * \\
(5.79)\end{array}$ & $\begin{array}{c}0.457 * * * \\
(4.12)\end{array}$ & $\begin{array}{c}-0.075^{* * * *} \\
(-4.15)\end{array}$ & $\begin{array}{c}-0.064 * * * * \\
(-3.01)\end{array}$ \\
\hline Lag Bond BAS & $\begin{array}{c}0.098^{* *} \\
(2.28)\end{array}$ & $\begin{array}{c}0.086^{*} \\
(1.79)\end{array}$ & $\begin{array}{c}0.086^{*} \\
(1.78)\end{array}$ & $\begin{array}{l}0.007 \\
(0.61)\end{array}$ & $\begin{array}{l}0.013 \\
(1.18)\end{array}$ & $\begin{array}{l}0.012 \\
(1.10)\end{array}$ & $\begin{array}{c}0.111^{* *} \\
(2.02)\end{array}$ & $\begin{array}{l}0.099 \\
(1.64)\end{array}$ & $\begin{array}{l}0.004 \\
(0.38)\end{array}$ & $\begin{array}{l}0.009 \\
(0.83)\end{array}$ & $\begin{array}{l}0.066 \\
(0.91)\end{array}$ & $\begin{array}{l}0.061 \\
(0.76)\end{array}$ & $\begin{array}{l}0.064 \\
(1.53)\end{array}$ & $\begin{array}{c}0.071^{*} \\
(1.66)\end{array}$ \\
\hline Lag Repo Net Order Flows & $\begin{array}{c}3.827 * * * \\
(6.22)\end{array}$ & $\begin{array}{c}3.645 * * * \\
(5.96)\end{array}$ & $\begin{array}{c}3.645 * * * \\
(5.98)\end{array}$ & $\begin{array}{c}0.614 * * * \\
(4.32)\end{array}$ & $\begin{array}{c}0.606^{* * * *} \\
(4.33)\end{array}$ & $\begin{array}{c}0.605 * * * \\
(4.32)\end{array}$ & $\begin{array}{c}3.896 * * * \\
(5.40)\end{array}$ & $\begin{array}{c}3.720 * * * \\
(5.17)\end{array}$ & $\begin{array}{c}0.663 * * * \\
(4.57)\end{array}$ & $\begin{array}{c}0.651 \text { **** } \\
(4.57)\end{array}$ & $\begin{array}{c}3.161 * * * \\
(3.41)\end{array}$ & $\begin{array}{c}2.998 * * * \\
(3.21)\end{array}$ & $\begin{array}{l}-0.887 \\
(-1.11)\end{array}$ & $\begin{array}{l}-0.858 \\
(-1.08)\end{array}$ \\
\hline Lag Repo Trades & $\begin{array}{c}0.418^{* * * *} \\
(3.41)\end{array}$ & $\begin{array}{c}0.396^{* * * *} \\
(3.27)\end{array}$ & $\begin{array}{c}0.396 * * * \\
(3.27)\end{array}$ & $\begin{array}{c}0.124 * * * \\
(5.14)\end{array}$ & $\begin{array}{c}0.130 * * * \\
(5.41)\end{array}$ & $\begin{array}{c}0.132 * * * \\
(5.53)\end{array}$ & $\begin{array}{c}0.523 * * * \\
(3.57)\end{array}$ & $\begin{array}{c}0.517 * * * \\
(3.57)\end{array}$ & $\begin{array}{c}0.113 * * * \\
(4.61)\end{array}$ & $\begin{array}{c}0.122 * * * \\
(5.08)\end{array}$ & $\begin{array}{l}0.310 \\
(1.43)\end{array}$ & $\begin{array}{l}0.248 \\
(1.15)\end{array}$ & $\begin{array}{c}0.539 * * * \\
(3.72)\end{array}$ & $\begin{array}{c}0.540 * * * \\
(3.73)\end{array}$ \\
\hline Lag Repo Volatility & $\begin{array}{c}1.544 * * * \\
(7.60)\end{array}$ & $\begin{array}{c}1.015 * * * \\
(4.17)\end{array}$ & $\begin{array}{c}1.015 * * * \\
(4.17)\end{array}$ & $\begin{array}{c}0.942 * * * \\
(6.79)\end{array}$ & $\begin{array}{c}0.878 * * * \\
(6.23)\end{array}$ & $\begin{array}{c}0.875 * * * \\
(6.17)\end{array}$ & $\begin{array}{c}1.572 * * * \\
(5.52)\end{array}$ & $\begin{array}{c}0.966 * * * \\
(2.64)\end{array}$ & $\begin{array}{c}1.199 * * * \\
(5.89)\end{array}$ & $\begin{array}{c}1.106 * * * \\
(5.33)\end{array}$ & $\begin{array}{c}1.619 * * * \\
(5.73)\end{array}$ & $\begin{array}{c}1.149 * * * \\
(3.53)\end{array}$ & $\begin{array}{c}0.461 * * * \\
(3.11)\end{array}$ & $\begin{array}{c}0.439 * * * \\
(2.89)\end{array}$ \\
\hline $\mathrm{CCP}$ & $\begin{array}{l}1.321 \\
(0.79)\end{array}$ & $\begin{array}{l}0.465 \\
(0.28)\end{array}$ & $\begin{array}{l}0.462 \\
(0.29)\end{array}$ & $\begin{array}{l}-0.939 \\
(-1.49)\end{array}$ & $\begin{array}{l}-0.948 \\
(-1.51)\end{array}$ & $\begin{array}{l}-1.188 \\
(-1.52)\end{array}$ & & & & & & & & \\
\hline Lag EL & $\begin{array}{c}-0.122^{* * * *} \\
(-7.34)\end{array}$ & $\begin{array}{c}-0.100 * * * \\
(-6.39)\end{array}$ & $\begin{array}{c}-0.100^{* * * *} \\
(-6.38)\end{array}$ & $\begin{array}{c}-0.093 * * * \\
(-22.48)\end{array}$ & $\begin{array}{c}-0.097 * * * \\
(-23.60)\end{array}$ & $\begin{array}{c}-0.097 * * * \\
(-23.69)\end{array}$ & $\begin{array}{c}-0.110 * * * \\
(-4.98)\end{array}$ & $\begin{array}{c}-0.090 * * * \\
(-4.31)\end{array}$ & $\begin{array}{c}-0.091 * * * \\
(-17.70)\end{array}$ & $\begin{array}{c}-0.096 * * * \\
(-19.04)\end{array}$ & $\begin{array}{c}-0.130 * * * \\
(-5.39)\end{array}$ & $\begin{array}{c}-0.109 * * * \\
(-4.79)\end{array}$ & $\begin{array}{c}-0.092 * * * \\
(-13.71)\end{array}$ & $\begin{array}{c}-0.094 * * * \\
(-14.05)\end{array}$ \\
\hline $\mathrm{Lag}_{\mathrm{EL}}{ }^{2}$ & $\begin{array}{c}0.080^{* *} \\
(2.35)\end{array}$ & $\begin{array}{l}0.028 \\
(0.85)\end{array}$ & $\begin{array}{l}0.028 \\
(0.85)\end{array}$ & $\begin{array}{c}0.085^{* * * *} \\
(18.58)\end{array}$ & $\begin{array}{c}0.087 * * * \\
(19.57)\end{array}$ & $\begin{array}{c}0.087 * * * \\
(19.70)\end{array}$ & $\begin{array}{l}0.032 \\
(0.70)\end{array}$ & $\begin{array}{l}-0.007 \\
(-0.15)\end{array}$ & $\begin{array}{c}0.084 * * * \\
(14.33)\end{array}$ & $\begin{array}{c}0.086^{* * * *} \\
(15.51)\end{array}$ & $\begin{array}{c}0.120^{* * *} \\
(2.44)\end{array}$ & $\begin{array}{l}0.063 \\
(1.33)\end{array}$ & $\begin{array}{c}0.080^{* * * *} \\
(11.39)\end{array}$ & $\begin{array}{c}0.081 * * * \\
(11.67)\end{array}$ \\
\hline Lag Excess Bank CDS & & $\begin{array}{c}0.112 * * * \\
(3.63)\end{array}$ & $\begin{array}{c}0.112 * * * \\
(3.16)\end{array}$ & & $\begin{array}{c}0.014 * * * \\
(3.05)\end{array}$ & $\begin{array}{c}0.012^{*} \\
(1.89)\end{array}$ & & $\begin{array}{c}0.115 * * * \\
(2.58)\end{array}$ & & $\begin{array}{c}0.017 * * * * \\
(2.80)\end{array}$ & & $\begin{array}{c}0.100^{* *} \\
(2.31)\end{array}$ & & $\begin{array}{l}0.007 \\
(1.04)\end{array}$ \\
\hline Lag Excess Bank CDS*CCP & & & $\begin{array}{c}0.001 \\
(-0.01) \\
\end{array}$ & & & $\begin{array}{l}0.004 \\
(0.50) \\
\end{array}$ & & & & & & & & \\
\hline Seasonal Controls & $\mathrm{Y}$ & $\mathrm{Y}$ & $\mathrm{Y}$ & $\mathrm{Y}$ & $\mathrm{Y}$ & $\mathrm{Y}$ & $\mathrm{Y}$ & $\mathrm{Y}$ & $\mathrm{Y}$ & $\mathrm{Y}$ & $\mathrm{Y}$ & $\mathrm{Y}$ & $\mathrm{Y}$ & $\mathrm{Y}$ \\
\hline Time-of-Day Effects & $\mathrm{Y}$ & $\mathrm{Y}$ & $\mathrm{Y}$ & $\mathrm{Y}$ & $\mathrm{Y}$ & $\mathrm{Y}$ & $\mathrm{Y}$ & $\mathrm{Y}$ & $\mathrm{Y}$ & $\mathrm{Y}$ & $\mathrm{Y}$ & $\mathrm{Y}$ & $\mathrm{Y}$ & $\mathrm{Y}$ \\
\hline Observations & 4,446 & 4,446 & 4,446 & 6,156 & 6,156 & 6,156 & 1,858 & 1,858 & 4,121 & 4,121 & 2,588 & 2,588 & 2,035 & 2,035 \\
\hline Adj. $R^{2}$ & 0.430 & 0.440 & 0.440 & 0.549 & 0.551 & 0.551 & 0.432 & 0.442 & 0.573 & 0.577 & 0.427 & 0.435 & 0.523 & 0.523 \\
\hline
\end{tabular}


Table C.2: Counterparty risk for large and small banks - additional regressors in model (5)

\section{Full repo sample}

This table reports the results of pooled OLS regression results over the period January 4, 2010 to November 30, 2015. Pooled regressions are estimated with HAC robust standard errors. The dependent variable is the GC Hourly Repo Spread. Variable definitions and measurements are explained in Table 5. Repo Net Order Flow is measured here in billions of euros. EL $^{2}$ is rescaled over 1,000. Excess Large Bank CDS and Excess Small Bank CDS (measured in basis points) are the average difference between the daily volume-weighted average CDS (senior five-year euro-denominated, obtained from Bloomberg) of larger and smaller banks (weighted by their relative market capitalisation) and the sovereign CDS. $* * *$ indicates $1 \%$; $* * 5 \%$; and $* 10 \%$ significance level, respectively. Columns 1-7 represent different specifications of equation (5).

\begin{tabular}{|c|c|c|c|c|c|c|c|}
\hline & \multicolumn{7}{|c|}{ Full Sample 04/01/2010 - 30/11/2015 } \\
\hline & (1) & (2) & (3) & (4) & $(5)$ & (6) & (7) \\
\hline Constant & $\begin{array}{c}18.707 * * * \\
(8.60)\end{array}$ & $\begin{array}{c}19.757 * * * \\
(9.00)\end{array}$ & $\begin{array}{c}19.548^{* * *} \\
(8.76)\end{array}$ & $\begin{array}{c}20.252^{* * *} \\
(9.15)\end{array}$ & $\begin{array}{c}20.052^{* * *} \\
(8.94)\end{array}$ & $\begin{array}{c}18.566 \text { *** } \\
(8.63)\end{array}$ & $\begin{array}{c}18.433 \text { *** } \\
(8.37)\end{array}$ \\
\hline Lag Bond Supply & $\begin{array}{c}0.157 * * * \\
(5.75)\end{array}$ & $\begin{array}{c}0.149 * * * \\
(5.52)\end{array}$ & $\begin{array}{c}0.148 * * * \\
(5.51)\end{array}$ & $\begin{array}{c}0.150 * * * \\
(5.56)\end{array}$ & $\begin{array}{c}0.149 * * * \\
(5.55)\end{array}$ & $\begin{array}{c}0.153 * * * \\
(5.64)\end{array}$ & $\begin{array}{c}0.153^{* * * *} \\
(5.64)\end{array}$ \\
\hline Lag Bond BAS & $\begin{array}{l}0.046 \\
(1.53)\end{array}$ & $\begin{array}{c}0.065^{* *} \\
(2.06)\end{array}$ & $\begin{array}{c}0.066^{* *} \\
(2.08)\end{array}$ & $\begin{array}{c}0.069 * * \\
(2.20)\end{array}$ & $\begin{array}{c}0.070^{* *} \\
(2.22)\end{array}$ & $\begin{array}{c}0.056^{*} \\
(1.81)\end{array}$ & $\begin{array}{c}0.057^{*} \\
(1.82)\end{array}$ \\
\hline Lag Repo Net Order Flows & $\begin{array}{c}2.110 * * * \\
(6.34)\end{array}$ & $\begin{array}{c}1.972 * * * \\
(6.05)\end{array}$ & $\begin{array}{c}1.979 * * * \\
(6.07)\end{array}$ & $\begin{array}{c}1.978 * * * \\
(6.08)\end{array}$ & $\begin{array}{c}1.987 * * * \\
(6.10)\end{array}$ & $\begin{array}{c}2.006^{* * * *} \\
(6.08)\end{array}$ & $\begin{array}{c}2.009 * * * \\
(6.09)\end{array}$ \\
\hline Lag Repo Trades & $\begin{array}{c}0.098 * * \\
(2.31)\end{array}$ & $\begin{array}{c}0.095 * * \\
(2.27)\end{array}$ & $\begin{array}{c}0.097 * * \\
(2.31)\end{array}$ & $\begin{array}{c}0.101 * * \\
(2.43)\end{array}$ & $\begin{array}{c}0.103 * * \\
(2.46)\end{array}$ & $\begin{array}{c}0.084 * * \\
(1.99)\end{array}$ & $\begin{array}{c}0.086^{* *} * \\
(2.02)\end{array}$ \\
\hline Lag Repo Volatility & $\begin{array}{c}1.639 * * * \\
(10.37)\end{array}$ & $\begin{array}{c}1.304 * * * \\
(7.89)\end{array}$ & $\begin{array}{c}1.295 * * * \\
(7.81)\end{array}$ & $\begin{array}{c}1.284 * * * \\
(7.75)\end{array}$ & $\begin{array}{c}1.275^{* * * *} \\
(7.66)\end{array}$ & $\begin{array}{c}1.442^{* * * *} \\
(8.80)\end{array}$ & $\begin{array}{c}1.437 * * * \\
(8.73)\end{array}$ \\
\hline $\mathrm{CCP}$ & $\begin{array}{l}-0.553 \\
(-0.51)\end{array}$ & $\begin{array}{l}-1.353 \\
(-1.25)\end{array}$ & $\begin{array}{l}-1.009 \\
(-0.88)\end{array}$ & $\begin{array}{l}-1.301 \\
(-1.21)\end{array}$ & $\begin{array}{l}-0.976 \\
(-0.88)\end{array}$ & $\begin{array}{l}-1.189 \\
(-1.09)\end{array}$ & $\begin{array}{l}-0.971 \\
(-0.77)\end{array}$ \\
\hline Lag EL & $\begin{array}{c}-0.141 * * * \\
(-17.61)\end{array}$ & $\begin{array}{c}-0.145^{* * *} \\
(-17.95)\end{array}$ & $\begin{array}{c}-0.145 * * * \\
(-17.95)\end{array}$ & $\begin{array}{c}-0.145 \text { *** } \\
(-17.98)\end{array}$ & $\begin{array}{c}-0.145^{* * *} * \\
(-17.97)\end{array}$ & $\begin{array}{c}-0.145 * * * \\
(-17.74)\end{array}$ & $\begin{array}{c}-0.144 * * * \\
(-17.74)\end{array}$ \\
\hline Lag $\mathrm{EL}^{2}$ & $\begin{array}{c}0.139 * * * \\
(15.65)\end{array}$ & $\begin{array}{c}0.131 * * * \\
(15.85)\end{array}$ & $\begin{array}{c}0.131 * * * \\
(15.83)\end{array}$ & $\begin{array}{c}0.130 * * * \\
(15.85)\end{array}$ & $\begin{array}{c}0.130 * * * \\
(15.82)\end{array}$ & $\begin{array}{c}0.136^{* * * *} \\
(15.85)\end{array}$ & $\begin{array}{c}0.136^{* * *} \\
(15.84)\end{array}$ \\
\hline Lag Excess Bank CDS & & $\begin{array}{c}0.072 * * * \\
(8.50)\end{array}$ & $\begin{array}{c}0.077 * * * \\
(6.46)\end{array}$ & & & & \\
\hline Lag Excess Bank CDS * CCP & & & $\begin{array}{l}-0.009 \\
(-0.76)\end{array}$ & & & & \\
\hline Lag Excess Large Bank CDS & & & & $\begin{array}{c}0.085 * * * \\
(8.52)\end{array}$ & $\begin{array}{c}0.092 * * * \\
(6.43)\end{array}$ & & \\
\hline Lag Excess Large Bank CDS * CCP & & & & & $\begin{array}{l}-0.013 \\
(-0.86)\end{array}$ & & \\
\hline Lag Excess Small Bank CDS & & & & & & $\begin{array}{c}0.027 * * * \\
(6.71)\end{array}$ & $\begin{array}{c}0.029 * * * \\
(5.03)\end{array}$ \\
\hline Lag Excess Small Bank CDS * CCP & & & & & & & $\begin{array}{l}-0.002 \\
(-0.39)\end{array}$ \\
\hline Seasonal Controls & $\mathrm{Y}$ & $\mathrm{Y}$ & Y & $\mathrm{Y}$ & $\mathrm{Y}$ & $\mathrm{Y}$ & $\mathrm{Y}$ \\
\hline Time-of-Day Effects & $\mathrm{Y}$ & Y & $\mathrm{Y}$ & $\mathrm{Y}$ & Y & Y & Y \\
\hline Observations & 10,602 & 10,602 & 10,602 & 10,602 & 10,602 & 10,602 & 10,602 \\
\hline Adj. $\mathrm{R}^{2}$ & 0.4760 & 0.4910 & 0.4910 & 0.4930 & 0.4930 & 0.4830 & 0.4830 \\
\hline
\end{tabular}




\section{Table C.3: Counterparty risk for large and small banks - additional regressors in model (5)}

\section{CCP-based repo and the bilateral repo samples}

This table reports the results of pooled OLS regression results over the period January 4, 2010 to November $30,2015$. Pooled regressions are estimated with HAC robust standard errors. The dependent variable is the GC Hourly Repo Spread. Variable definitions and measurements are explained in Table 5. Repo Net Order Flow is measured here in billions of euros. EL ${ }^{2}$ is rescaled over 1,000. Excess Large Bank CDS and Excess Small Bank CDS (measured in basis points) are the average difference between the daily volume-weighted average CDS (senior five-year euro-denominated, obtained from Bloomberg) of larger and smaller banks (weighted by their relative market capitalization) and the sovereign CDS. *** indicates 1\%; ** 5\%; and * 10\% significance level, respectively. Columns 1-4 represent different specifications of equation (5) for the subsample of CCP-based repos, columns 5-8 represent the same specifications but on the subsample of bilateral repos.

\begin{tabular}{|c|c|c|c|c|c|c|c|c|}
\hline \multirow[t]{2}{*}{ Repos } & \multicolumn{4}{|c|}{ CCP-based } & \multicolumn{4}{|c|}{ Bilateral } \\
\hline & (1) & (2) & (3) & (4) & (5) & (6) & (7) & (8) \\
\hline Constant & $\begin{array}{c}19.835^{* * *} \\
(7.65)\end{array}$ & $\begin{array}{c}21.090 * * * \\
(8.01)\end{array}$ & $\begin{array}{c}21.602 * * * \\
(8.12)\end{array}$ & $\begin{array}{c}19.866^{* * *} \\
(7.71)\end{array}$ & $\begin{array}{c}14.001 * * * \\
(8.02)\end{array}$ & $\begin{array}{c}14.834 * * * \\
(8.54)\end{array}$ & $\begin{array}{c}15.493^{* * *} \\
(8.86)\end{array}$ & $\begin{array}{c}13.390 * * * \\
(7.75)\end{array}$ \\
\hline Lag Bond Supply & $\begin{array}{c}0.106^{* * * *} \\
(3.72)\end{array}$ & $\begin{array}{c}0.106^{* * * *} \\
(3.71)\end{array}$ & $\begin{array}{c}0.108 * * * \\
(3.78)\end{array}$ & $\begin{array}{c}0.107 * * * \\
(3.73)\end{array}$ & $\begin{array}{c}0.234 * * * \\
(10.24)\end{array}$ & $\begin{array}{c}0.212^{* * *} \\
(9.46)\end{array}$ & $\begin{array}{c}0.210^{* * * *} \\
(9.38)\end{array}$ & $\begin{array}{c}0.224 * * * \\
(9.95)\end{array}$ \\
\hline Lag Bond BAS & $\begin{array}{l}0.054 \\
(1.52)\end{array}$ & $\begin{array}{c}0.065^{*} \\
(1.81)\end{array}$ & $\begin{array}{c}0.070 * \\
(1.94)\end{array}$ & $\begin{array}{l}0.058 \\
(1.61)\end{array}$ & $\begin{array}{l}0.024 \\
(0.96)\end{array}$ & $\begin{array}{c}0.055^{* *} \\
(2.12)\end{array}$ & $\begin{array}{c}0.058 * * \\
(2.23)\end{array}$ & $\begin{array}{c}0.043 * \\
(1.70)\end{array}$ \\
\hline Lag Repo Net Order Flows & $\begin{array}{c}0.002 * * * \\
(5.99)\end{array}$ & $\begin{array}{c}0.002 * * * \\
(5.71)\end{array}$ & $\begin{array}{c}0.002 * * * \\
(5.72)\end{array}$ & $\begin{array}{c}0.002 * * * \\
(5.75)\end{array}$ & $\begin{array}{c}0.003 * * * \\
(4.10)\end{array}$ & $\begin{array}{c}0.003 * * * \\
(3.90)\end{array}$ & $\begin{array}{c}0.003 * * * \\
(3.91)\end{array}$ & $\begin{array}{c}0.003 * * * \\
(3.95)\end{array}$ \\
\hline Lag Repo Trades & $\begin{array}{c}0.132 * * * \\
(2.81)\end{array}$ & $\begin{array}{c}0.115^{* *} \\
(2.47)\end{array}$ & $\begin{array}{c}0.121 * * * \\
(2.63)\end{array}$ & $\begin{array}{c}0.106^{* *} \\
(2.26)\end{array}$ & $\begin{array}{c}0.713 * * * \\
(4.40)\end{array}$ & $\begin{array}{c}0.723 * * * \\
(4.50)\end{array}$ & $\begin{array}{c}0.700 * * * \\
(4.36)\end{array}$ & $\begin{array}{c}0.767 * * * \\
(4.74)\end{array}$ \\
\hline Lag Repo Volatility & $\begin{array}{c}1.698 * * * \\
(7.55)\end{array}$ & $\begin{array}{c}1.440 * * * \\
(6.29)\end{array}$ & $\begin{array}{c}1.413 * * * \\
(6.16)\end{array}$ & $\begin{array}{c}1.563 * * * \\
(6.83)\end{array}$ & $\begin{array}{c}1.651 * * * \\
(15.19)\end{array}$ & $\begin{array}{c}1.225 * * * \\
(10.39)\end{array}$ & $\begin{array}{c}1.219 * * * \\
(10.37)\end{array}$ & $\begin{array}{c}1.380 * * * \\
(11.73)\end{array}$ \\
\hline Lag EL & $\begin{array}{c}-0.136^{* * *} \\
(-13.25)\end{array}$ & $\begin{array}{c}-0.141 * * * \\
(-13.50)\end{array}$ & $\begin{array}{c}-0.142 * * * \\
(-13.52)\end{array}$ & $\begin{array}{c}-0.140 * * * \\
(-13.33)\end{array}$ & $\begin{array}{c}-0.138 * * * \\
(-27.46)\end{array}$ & $\begin{array}{c}-0.140 * * * \\
(-28.03)\end{array}$ & $\begin{array}{c}-0.140 * * * \\
(-27.98)\end{array}$ & $\begin{array}{c}-0.140 * * * \\
(-27.90)\end{array}$ \\
\hline Lag $\mathrm{EL}^{2}$ & $\begin{array}{c}0.132 * * * \\
(11.70)\end{array}$ & $\begin{array}{c}0.128 * * * \\
(12.02)\end{array}$ & $\begin{array}{c}0.128 * * * \\
(12.04)\end{array}$ & $\begin{array}{c}0.131 * * * \\
(11.90)\end{array}$ & $\begin{array}{c}0.138 * * * \\
(24.72)\end{array}$ & $\begin{array}{c}0.125 * * * \\
(23.88)\end{array}$ & $\begin{array}{c}0.125 * * * \\
(23.81)\end{array}$ & $\begin{array}{c}0.131 * * * \\
(24.49)\end{array}$ \\
\hline Lag Excess Bank CDS & & $\begin{array}{c}0.061 * * * \\
(6.15)\end{array}$ & & & & $\begin{array}{c}0.082 * * * \\
(13.46)\end{array}$ & & \\
\hline Lag Excess Large Bank CDS & & & $\begin{array}{c}0.073 * * * \\
(6.22)\end{array}$ & & & & $\begin{array}{c}0.096 * * * \\
(13.44)\end{array}$ & \\
\hline Lag Excess Small Bank CDS & & & & $\begin{array}{c}0.023 * * * \\
(4.70)\end{array}$ & & & & $\begin{array}{c}0.031 * * * \\
(10.30)\end{array}$ \\
\hline Seasonal Controls & $\mathrm{Y}$ & $\mathrm{Y}$ & $\mathrm{Y}$ & $\mathrm{Y}$ & $\mathrm{Y}$ & $\mathrm{Y}$ & $\mathrm{Y}$ & $\mathrm{Y}$ \\
\hline Time-of-Day Effects & $\mathrm{Y}$ & $\mathrm{Y}$ & $\mathrm{Y}$ & $\mathrm{Y}$ & $\mathrm{Y}$ & $\mathrm{Y}$ & $\mathrm{Y}$ & $\mathrm{Y}$ \\
\hline Observations & 5,979 & 5,979 & 5,979 & 5,979 & 4,623 & 4,623 & 4,623 & 4,623 \\
\hline Adj. $\mathrm{R}^{2}$ & 0.502 & 0.515 & 0.517 & 0.508 & 0.461 & 0.477 & 0.479 & 0.468 \\
\hline
\end{tabular}




\section{Appendix D. Robustness checks on the results of section 4}

We perform several robustness checks on the main results of Section 4. First, to evaluate the impact of the European systemic risk and monetary policy expectations on the repo spread we estimate a parsimonious model that uses only the excess liquidity, the squared excess liquidity, a proxy for systemic risk in the European financial markets and a proxy for monetary policy expectations as explanatory variables (Table D.1, column 1) without including any of the collateral and repo factors. ${ }^{25}$ As a proxy for systemic risk in the European financial markets we use the composite indicator of systemic stress (CISS) (see Hollo, Kremer and Lo Duca., 2012) on day $t$ - 1 which aggregates 15 different financial stress measures. We find a positive and significant effect of CISS on the repo spread. In times of crisis, higher systemic risk induces repo lenders to charge a higher 'premium'. Additionally, we control for expected ECB monetary policy changes (EMPC), i.e. given by the difference between the one-month EONIA futures and the EONIA rate on day $t-1$ (see Gürkaynak, Sack and Swanson, 2007). We find a significant negative relation between EMPC and repo spread. A negative EMPC means lower expected future rates and signals higher future systemic risk at the Eurozone level: this worsens the Italian repo market conditions and leads to higher repo spreads. This model reported in Table D.1, column 1, has an adjusted $\mathrm{R}^{2}$ of about $43 \%$. Interestingly, we also observe that the CCP dummy is insignificant. This suggests that when we account for systemic risk and changes in ECB policy, the risk-mitigating function of the CCP becomes of 'second-order importance' for the Italian repo spread. Next, in Table D.1, column 2, we re-introduce the collateral and repo factors along with EL, CISS and EMPC. As we use EL, we exclude bond modified duration given their high correlation. The results for all of the collateral and

\footnotetext{
${ }^{25}$ We also control for the impact on the intraday repo spread of: Italian sovereign five-year CDS, VSTOXX EUR, EURIBOR-OIS spread and EONIA volumes. Results are not reported for brevity, but are available upon request. Finally, we control for the impact of economic news on the intraday repo spread, but we do not find such impact. For this control, we apply a methodology similar to Paiardini (2014). We argue that macroeconomic news may be anticipated by banks and already reflected in the prices of repo trades.
} 
repo variables remain mostly invariant and consistent with our main regression results in Table 7.

The model has a higher explanatory power (adjusted $\mathrm{R}^{2}$ of $52.6 \%$ ). CISS is now only marginally

significant: this mean that our more parsimonious model (5) without CISS already captures the

effect of the Eurozone systemic stress.

\section{Table D.1: Pooled regressions results with alternative combinations of factors for overall sample period}

This table reports the results of pooled OLS regressions estimated with HAC robust standard errors over the period January 4, 2010 to November 30, 2015. The dependent variable is the GC Hourly Repo Spread. Variable definitions and measurements are explained in Table 5. Repo Net Order Flow is measured here in billions of euros. $\mathrm{EL}^{2}$ is rescaled over 1,000. CISS is the composite indicator of systemic stress, which aggregates 15 different financial stress measures (Hollo et al., 2012). EMPC is the difference between the one-month EONIA futures and the EONIA rate and measures the expected monetary policy changes (in basis points). T-statistics are reported in brackets. *** indicates 1\%; ** 5\%; and * $10 \%$ significance level, respectively.. Columns (1) and (2) represent two different specifications for the regression equation.

\begin{tabular}{lcc}
\hline & $(1)$ & $(2)$ \\
\hline Ind. Variables: & & $0.162^{* * * *}$ \\
Lag Bond Supply & & $(12.00)$ \\
& & $0.054^{* * *}$ \\
Lag Bond BAS & & $(3.78)$ \\
& & \\
Lag Bond Mod. Duration & & \\
& & $1.930^{* * *}$ \\
Lag Repo Net Order Flows & & $(9.08)$ \\
& & $0.075^{* *}$ \\
Lag Repo Trades & & $(2.22)$ \\
& & $1.541^{* * *}$ \\
Lag Repo Volatility & 0.618 & $(20.64)$ \\
& $(1.01)$ & -0.961 \\
CCP & $-0.123^{* * *}$ & $(-1.58)$ \\
& $(-34.82)$ & $-0.126^{* * *}$ \\
Lag EL & $0.106^{* * * *}$ & $(-39.04)$ \\
& $(24.73)$ & $0.123^{* * *}$ \\
Lag EL & $(32.91)$ \\
& & \\
Other Controls: & $26.321^{* * *}$ & 0.358 \\
Lag CISS & $(14.92)$ & $(0.21)$ \\
& $-45.289^{* * *}$ & $-41.909^{* * *}$ \\
Lag EMPC & $(-19.04)$ & $(-18.11)$ \\
& $\mathrm{Y}$ & $\mathrm{Y}$ \\
\hline Seasonal Controls & $\mathrm{Y}$ & $\mathrm{Y}$ \\
Time-of-day Effects & 10,602 & 10,602 \\
Observations & 0.426 & 0.526 \\
Adj. R ${ }^{2}$ & & \\
\hline
\end{tabular}


Second, we control whether the impact of the explanatory variables changes over the hours of the day. We add to the baseline regression model (5) the interaction terms between each explanatory variable and the hourly dummies. In unreported results, we notice that the impact of the collateral variables decreases over the first hours of the trading day and then it reaches a stable level after 11:00 a.m. However, these interaction terms are not statistically significant.

Third, in Table D.2 we repeat the main regression analysis on repo spreads with hourly Bond Supply and Bond BAS constructed from portfolios of bonds used as collateral in the previous day, the previous week, the previous two weeks, and the previous two months. The original results of Table 7 with hourly Bond Supply and Bond BAS constructed using the collateral information from the previous 22 days (one month) are reported in columns (4), (9) and (14) for comparison. Table D.2 shows that results do not change. 
Table D.2: Pooled regressions results with bond variables derived from other time windows.

This table reports the results of pooled OLS regressions estimated with HAC robust standard errors over the period January 4, 2010 to November 30, 2015 where Bond Supply and Bond BAS are derived from time window of 1 day, 1 week, 2 weeks, 1 month (22 days) and 2 months, respectively. The dependent variable is the GC Hourly Repo Spread. Variable definitions and measurements are explained in Table 5. Repo Net Order Flow is measured here in billions of euros. EL ${ }^{2}$ is rescaled over 1,000. CISS is the composite indicator of systemic stress, which aggregates 15 different financial stress measures (Hollo et al., 2012). EMPC is the difference between the one-month EONIA futures and the EONIA rate and measures the expected monetary policy changes (in basis points). T-statistics are reported in brackets. *** indicates 1\%; ** 5\%; and * 10\% significance level, respectively.

\begin{tabular}{|c|c|c|c|c|c|c|c|c|c|c|c|c|c|c|c|}
\hline & \multicolumn{5}{|c|}{ All Repos } & \multicolumn{5}{|c|}{ CCP-based Repos } & \multicolumn{5}{|c|}{ Bilateral Repos } \\
\hline & \multicolumn{15}{|c|}{ Collateral Weights } \\
\hline & 1 day & 1 week & 2 weeks & 1 month & 2 months & 1 day & 1 week & 2 weeks & 1 month & 2 months & 1 day & 1 week & 2 weeks & 1 month & 2 months \\
\hline & $(1)$ & (2) & (3) & (4) & (5) & (6) & (7) & $(8)$ & (9) & (10) & $(11)$ & $(12)$ & (13) & (14) & (15) \\
\hline Constant & $\begin{array}{c}20.000 * * * * \\
(8.51)\end{array}$ & $\begin{array}{c}19.457 * * * \\
(8.39)\end{array}$ & $\begin{array}{c}19.036 * * * \\
(8.29)\end{array}$ & $\begin{array}{c}18.707 * * * \\
(8.60)\end{array}$ & $\begin{array}{c}16.836^{* * * *} \\
(7.51)\end{array}$ & $\begin{array}{c}20.283^{* * * *} \\
(6.49)\end{array}$ & $\begin{array}{c}19.826 * * * \\
(6.54)\end{array}$ & $\begin{array}{c}19.358 * * * \\
(6.55)\end{array}$ & $\begin{array}{c}19.835 * * * \\
(7.65)\end{array}$ & $\begin{array}{c}17.113^{* * * *} \\
(5.94)\end{array}$ & $\begin{array}{c}15.385 * * * \\
(4.35)\end{array}$ & $\begin{array}{c}14.501 * * * \\
(4.12)\end{array}$ & $\begin{array}{c}14.075^{* * * *} \\
(3.99)\end{array}$ & $\begin{array}{c}14.001 * * * \\
(3.81)\end{array}$ & $\begin{array}{c}11.707 * * * * \\
(3.41)\end{array}$ \\
\hline Lag Bond Supply & $\begin{array}{c}0.132^{* * *} \\
(4.21)\end{array}$ & $\begin{array}{c}0.142 * * * \\
(4.66)\end{array}$ & $\begin{array}{c}0.153 * * * * \\
(5.01)\end{array}$ & $\begin{array}{c}0.157 * * * \\
(5.75)\end{array}$ & $\begin{array}{c}0.210^{* * * *} \\
(6.62)\end{array}$ & $\begin{array}{c}0.093 * * \\
(2.43)\end{array}$ & $\begin{array}{c}0.100 * * * \\
(2.74)\end{array}$ & $\begin{array}{c}0.109 * * * \\
(3.08)\end{array}$ & $\begin{array}{c}0.106^{* * * *} \\
(3.72)\end{array}$ & $\begin{array}{c}0.156^{* * * *} \\
(4.24)\end{array}$ & $\begin{array}{c}0.211^{*} * * * \\
(3.99)\end{array}$ & $\begin{array}{c}0.226 * * * \\
(4.39)\end{array}$ & $\begin{array}{c}0.238^{* * * *} \\
(4.52)\end{array}$ & $\begin{array}{c}0.234 * * * \\
(4.58)\end{array}$ & $\begin{array}{c}0.307 * * * \\
(5.62)\end{array}$ \\
\hline Lag Bond BAS & $\begin{array}{l}0.001 \\
(0.02)\end{array}$ & $\begin{array}{l}-0.004 \\
(-0.09)\end{array}$ & $\begin{array}{l}0.015 \\
(0.38)\end{array}$ & $\begin{array}{l}0.046 \\
(1.53)\end{array}$ & $\begin{array}{c}0.122 * * * \\
(2.85)\end{array}$ & $\begin{array}{l}0.028 \\
(0.46)\end{array}$ & $\begin{array}{l}0.026 \\
(0.45)\end{array}$ & $\begin{array}{l}0.041 \\
(0.76)\end{array}$ & $\begin{array}{l}0.054 \\
(1.52)\end{array}$ & $\begin{array}{c}0.137 * * \\
(2.44)\end{array}$ & $\begin{array}{l}-0.018 \\
(-0.28)\end{array}$ & $\begin{array}{l}-0.023 \\
(-0.38)\end{array}$ & $\begin{array}{l}-0.001 \\
(-0.01)\end{array}$ & $\begin{array}{l}0.024 \\
(0.41)\end{array}$ & $\begin{array}{c}0.117^{*} \\
(1.76)\end{array}$ \\
\hline Lag Repo Net Order Flows & $\begin{array}{c}2.190 * * * \\
(6.61)\end{array}$ & $\begin{array}{c}2.171 * * * \\
(6.55)\end{array}$ & $\begin{array}{c}2.167 * * * \\
(6.55)\end{array}$ & $\begin{array}{c}2.110 * * * \\
(6.34)\end{array}$ & $\begin{array}{c}2.127 * * * \\
(6.60)\end{array}$ & $\begin{array}{c}2.188 * * * \\
(6.14)\end{array}$ & $\begin{array}{c}2.178 * * * \\
(6.11)\end{array}$ & $\begin{array}{c}2.172 * * * \\
(6.11)\end{array}$ & $\begin{array}{c}2.141 * * * \\
(5.99)\end{array}$ & $\begin{array}{c}2.119 * * * \\
(6.15)\end{array}$ & $\begin{array}{c}2.928 * * * \\
(3.59)\end{array}$ & $\begin{array}{c}2.877 * * * \\
(3.56)\end{array}$ & $\begin{array}{c}2.913 * * * \\
(3.60)\end{array}$ & $\begin{array}{c}2.939 * * * \\
(3.60)\end{array}$ & $\begin{array}{c}2.996 * * * \\
(3.71)\end{array}$ \\
\hline Lag Repo Trades & $\begin{array}{c}0.122 * * * \\
(3.01)\end{array}$ & $\begin{array}{c}0.116^{* * * *} \\
(2.88)\end{array}$ & $\begin{array}{c}0.117 * * * \\
(2.90)\end{array}$ & $\begin{array}{c}0.098^{* *} \\
(2.31)\end{array}$ & $\begin{array}{c}0.122 * * * \\
(3.02)\end{array}$ & $\begin{array}{c}0.132 * * * \\
(3.02)\end{array}$ & $\begin{array}{c}0.127 * * * \\
(2.91)\end{array}$ & $\begin{array}{c}0.127 * * * \\
(2.92)\end{array}$ & $\begin{array}{c}0.132 * * * * \\
(2.81)\end{array}$ & $\begin{array}{c}0.132 * * * \\
(3.02)\end{array}$ & $\begin{array}{c}0.795 * * * \\
(4.41)\end{array}$ & $\begin{array}{c}0.813 * * * \\
(4.47)\end{array}$ & $\begin{array}{c}0.819 * * * \\
(4.50)\end{array}$ & $\begin{array}{c}0.713 * * * \\
(3.94)\end{array}$ & $\begin{array}{c}0.822 * * * \\
(4.48)\end{array}$ \\
\hline Lag Repo Volatility & $\begin{array}{c}1.830 * * * \\
(9.72)\end{array}$ & $\begin{array}{c}1.859 * * * \\
(10.45)\end{array}$ & $\begin{array}{c}1.790 * * * \\
(9.99)\end{array}$ & $\begin{array}{c}1.639 * * * * \\
(10.37)\end{array}$ & $\begin{array}{c}1.428 * * * \\
(8.08)\end{array}$ & $\begin{array}{c}1.834 * * * \\
(6.87)\end{array}$ & $\begin{array}{c}1.854 * * * \\
(7.06)\end{array}$ & $\begin{array}{c}1.798 * * * \\
(6.91)\end{array}$ & $\begin{array}{c}1.698 * * * \\
(7.55)\end{array}$ & $\begin{array}{c}1.472 * * * \\
(5.81)\end{array}$ & $\begin{array}{c}1.815^{* * * *} \\
(6.86)\end{array}$ & $\begin{array}{c}1.847 * * * \\
(7.59)\end{array}$ & $\begin{array}{c}1.765 * * * \\
(7.00)\end{array}$ & $\begin{array}{c}1.651 * * * \\
(6.86)\end{array}$ & $\begin{array}{c}1.364 * * * \\
(5.49)\end{array}$ \\
\hline $\mathrm{CCP}$ & $\begin{array}{l}-1.179 \\
(-1.08)\end{array}$ & $\begin{array}{l}-1.263 \\
(-1.15)\end{array}$ & $\begin{array}{l}-1.314 \\
(-1.20)\end{array}$ & $\begin{array}{l}-0.553 \\
(-0.51)\end{array}$ & $\begin{array}{l}-1.464 \\
(-1.35)\end{array}$ & & & & & & & & & & \\
\hline Lag EL & $\begin{array}{c}-0.142 * * * \\
(-17.73)\end{array}$ & $\begin{array}{c}-0.142 * * * \\
(-17.73)\end{array}$ & $\begin{array}{c}-0.142 * * * \\
(-17.72)\end{array}$ & $\begin{array}{c}-0.141 * * * \\
(-17.61)\end{array}$ & $\begin{array}{c}-0.146 * * * \\
(-18.21)\end{array}$ & $\begin{array}{c}-0.135 * * * \\
(-13.31)\end{array}$ & $\begin{array}{c}-0.135^{* * *} * \\
(-13.25)\end{array}$ & $\begin{array}{c}-0.136 * * * \\
(-13.25)\end{array}$ & $\begin{array}{c}-0.136 * * * \\
(-13.25)\end{array}$ & $\begin{array}{c}-0.139 * * * \\
(-13.60)\end{array}$ & $\begin{array}{c}-0.141 * * * \\
(-11.37)\end{array}$ & $\begin{array}{c}-0.141 * * * \\
(-11.36)\end{array}$ & $\begin{array}{c}-0.142 * * * \\
(-11.34)\end{array}$ & $\begin{array}{c}-0.138^{* * *} * \\
(-11.09)\end{array}$ & $\begin{array}{c}-0.147 * * * \\
(-11.72)\end{array}$ \\
\hline Lag EL ${ }^{2}$ & $\begin{array}{c}0.141 * * * \\
(15.80) \\
\end{array}$ & $\begin{array}{c}0.141 * * * \\
(15.81) \\
\end{array}$ & $\begin{array}{c}0.141 * * * \\
(15.81) \\
\end{array}$ & $\begin{array}{c}0.139 * * * \\
(15.65) \\
\end{array}$ & $\begin{array}{c}0.144 * * * \\
(16.01) \\
\end{array}$ & $\begin{array}{c}0.132 * * * \\
(11.67) \\
\end{array}$ & $\begin{array}{c}0.132 * * * \\
(11.66) \\
\end{array}$ & $\begin{array}{c}0.132 * * * \\
(11.67) \\
\end{array}$ & $\begin{array}{c}0.132 * * * \\
(11.70) \\
\end{array}$ & $\begin{array}{c}0.134 * * * \\
(11.77) \\
\end{array}$ & $\begin{array}{c}0.142 * * * \\
(10.34) \\
\end{array}$ & $\begin{array}{c}0.142 * * * \\
(10.35) \\
\end{array}$ & $\begin{array}{c}0.142 * * * \\
(10.33) \\
\end{array}$ & $\begin{array}{c}0.138 * * * \\
(9.99) \\
\end{array}$ & $\begin{array}{c}0.145^{* * * *} \\
(10.54) \\
\end{array}$ \\
\hline $\begin{array}{c}\text { Seasonal Effects } \\
\text { (excluding day of the week } \\
\text { effects) }\end{array}$ & $\mathrm{Y}$ & Y & $\mathrm{Y}$ & $\mathrm{Y}$ & $\mathrm{Y}$ & $\mathrm{Y}$ & $\mathrm{Y}$ & Y & Y & $\mathrm{Y}$ & Y & Y & Y & $\mathrm{Y}$ & $\mathrm{Y}$ \\
\hline Day of the week effects & $\mathrm{Y}$ & $\mathrm{Y}$ & $\mathrm{Y}$ & $\mathrm{Y}$ & $\mathrm{Y}$ & $\mathrm{Y}$ & $\mathrm{Y}$ & $\mathrm{Y}$ & $\mathrm{Y}$ & $\mathrm{Y}$ & $\mathrm{Y}$ & Y & $\mathrm{Y}$ & $\mathrm{Y}$ & $\mathrm{Y}$ \\
\hline Time-of-Day Effects & Y & Y & Y & Y & Y & $\mathrm{Y}$ & $\mathrm{Y}$ & $\mathrm{Y}$ & $\mathrm{Y}$ & $\mathrm{Y}$ & $\mathrm{Y}$ & $\mathrm{Y}$ & $\mathrm{Y}$ & $\mathrm{Y}$ & $\mathrm{Y}$ \\
\hline Observations & 10,602 & 10,602 & 10,602 & 10,602 & 10,602 & 5,979 & 5,979 & 5,979 & 5,979 & 5,979 & 4,623 & 4,623 & 4,623 & 4,623 & 4,623 \\
\hline Adj. $\mathrm{R}^{2}$ & 0.474 & 0.475 & 0.476 & 0.476 & 0.479 & 0.499 & 0.499 & 0.500 & 0.500 & 0.506 & 0.458 & 0.460 & 0.459 & 0.457 & 0.462 \\
\hline
\end{tabular}




\section{References}

Abbassi, P., Fecht, F., Tischer, J., 2017. Variations in market liquidity and the intraday interest rate. Journal of Money, Credit and Banking 49 (4), 733-765.

Angelini, P., 1998. An analysis of competitive externalities in gross settlement systems. Journal of Banking \& Finance 22 (1), 1-18.

Angelini, P., 2000. Are banks risk averse? Intraday timing of operations in the interbank market. Journal of Money, Credit and Banking 32 (1), 54-73.

Baglioni, A., Monticini, A., 2008. The intraday price of money: Evidence from the e-MID interbank market. Journal of Money, Credit and Banking 40 (7), 1533-1540.

Baglioni, A., Monticini, A., 2010. The intraday interest rate under a liquidity crisis: The case of August 2007. Economics Letters 107 (2), 198-200.

Baglioni, A., Monticini, A., 2013. Why does the interest rate decline over the day? Evidence from the liquidity crisis. Journal of Financial Services Research 44 (2), 175-186.

Bank of Italy, 2012. Financial Stability Report No. 3, April.

Bartolini, L., Gudell, S., Hilton, S., Schwarz, K., 2005. Intraday trading in the overnight federal funds market. Current Issues in Economics and Finance 11 (11).

Bech, M.L., Garratt, R., 2003. The intraday liquidity management game. Journal of Economic Theory 109 (2), 198-219.

Boissel, C., Derrien, F., Ors, E., Thesmar, D., 2017. Systemic risk in clearing houses: Evidence from the European repo market. Journal of Financial Economics 125(3), 511-536. 
Brunnermeier, M.K., Pedersen, L.H., 2009. Market liquidity and funding liquidity. Review of Financial Studies 22 (6), 2201-2238.

Darbha, M., Dufour, A. (2013). Microstructure of the Euro-area government bond market. In: Kent Baker, H., Kiymaz, H. (Eds.), Market Microstructure in Emerging and Developed Markets: Price Discovery, Information Flows, and Transaction Costs. Wiley, New Jersey, 39-58.

Domanski, D., Gambacorta, L., Picillo, C., 2015. Central clearing: Trends and current issues. BIS Quarterly Review, December 2015.

Duffie, D., 1996. Special repo rates. Journal of Finance 51 (2), 493-526.

Dufour, A., Marra, M., Sangiorgi, I., Skinner, F., 2019. Explaining repo specialness. International Journal of Finance \& Economics. In Press.

Dunne, P., Everett, M., Stuart, R., 2015. The expanded asset purchase programme - what, why and how of Euro area QE. Quarterly Bulletin Articles, 61-71.

Dunne, P.G., Fleming, M.J., Zholos, A., 2017. ECB monetary operations and the interbank repo market. Working paper, Central Bank of Ireland.

Furfine, C.H., 2001. Banks as monitors of other banks: Evidence from the overnight federal funds market. Journal of Business 74 (1), 33-57.

Gürkaynak, R.S., Sack, B.P., Swanson, E.T., 2007. Market-based measures of monetary policy expectations. Journal of Business and Economic Statistics 25, 201-212.

Hausman, J.A., 1978. Specification tests in econometrics. Econometrica 46 (6), 1251-1272.

Hollo, D., Kremer, M., Lo Duca, M., 2012. CISS - a composite indicator of systemic stress in the financial system. Working paper, European Central Bank and National Bank of Hungary. 
International Monetary Fund, 2013. Italy: Financial system stability assessment. IMF Country Report No. 13/300, September.

Jurgilas, M., Žikeš, F., 2014. Implicit intraday interest rate in the UK unsecured overnight money market. Journal of Financial Intermediation 23 (2), 232-254.

Kraenzlin, S., Nellen, T., 2010. Daytime is money. Journal of Money, Credit and Banking 42 (8), $1689-1702$.

Mansfield, E. R., Helms, B. P., 1982. Detecting multicollinearity. The American Statistician 36 (3a), 158-160.

Mancini, L., Ranaldo, A., Wrampelmeyer, J., 2016. The Euro interbank repo market. Review of Financial Studies 29 (7), 1747-1779.

Paiardini, P., 2014. The impact of economic news on bond prices: Evidence from the MTS platform. Journal of Banking and Finance 49, 302-322.

Pelizzon, L., Subrahmanyam, M., Tomio, D., Uno, J., 2016. Sovereign credit crisis, liquidity, and ECB intervention: Deus ex machina? Journal of Financial Economics 122 (1), 86-115.

Quiros, G. P., Mendizabal, H. R., 2006. The daily market for funds in Europe: what has changed with the EMU? Journal of Money, Credit and Banking 38 (1), 91-118.

Van Hoose, D.D., 1991. Bank behavior, interest rate determination, and monetary policy in a financial system with an intraday federal funds market. Journal of Banking and Finance 15 (2), 343-365. 


\section{TABLES AND FIGURES}

\section{Table 1: The MTS GC repo market}

The table reports summary statistics for the daily repo volume (as total notional value of collateral in transacted repo contracts measured in millions of euros) used in MTS for ON GC CCP-based and bilateral repo transactions in Panel A, and the number of Italian sovereign bonds used as collateral in ON GC repo transactions on MTS according to class of bond, maturity group and type of repo in Panel B, over the period from January 4, 2010 to November 30, 2015. Panel B also reports the total number of Italian sovereign bonds used as collateral in repo transactions recorded on MTS over the same period (by maturity group and by repo type). The column "All" indicates all bonds used at least once as repo collateral in either CCP-based repo transactions or in bilateral repo transactions (the same bond can be used for both types of repos). The classes of bonds issued by the Italian Treasury are: Buoni del Tesoro Pluriennali (BTPs), which are fixed coupon-bearing bonds; Buoni del Tesoro Pluriennali indicizzati (BTIs), which are inflation-linked coupon-bearing bonds; Buoni Ordinari del Tesoro (BOTs), which are treasury bills; Certificati del Tesoro Zero-Coupon (CTZs), which are zero-coupon bonds; and Certificati di Credito del Tesoro (CCTs), which are floating notes.

Panel A: Transacted volumes (i.e. total notional value) of MTS repo market

\begin{tabular}{llll}
\hline Cash Volumes & $\begin{array}{l}\text { CCP-based } \\
(€ \text { millions })\end{array}$ & $\begin{array}{l}\text { Bilateral Repos } \\
(€ \text { millions })\end{array}$ & $\begin{array}{l}\text { Total } \\
(€ \text { millions })\end{array}$ \\
\hline Daily Average & $5,004.29$ & $1,140.76$ & $6,083.53$ \\
Standard & $1,703.30$ & $1,265.59$ & $2,165.68$ \\
Deviation & 465.00 & 5.00 & $1,484.00$ \\
Minimum & $12,254.50$ & $8,270.00$ & $16,816.00$ \\
Maximum & $1,502.00$ & $1,421.00$ & $1,502.00$ \\
Trading Days & $7,516,449.00$ & $1,621,013.50$ & $9,137,462.50$ \\
Total &
\end{tabular}

Panel B: Number of bonds used in repo transactions

\begin{tabular}{lcccc}
\hline Bond Class & Maturity Group & \multicolumn{3}{c}{ Sample Bonds used as Repo Collaterals } \\
\cline { 2 - 5 } & 3 & CCP-based & Bilateral & All \\
\cline { 2 - 5 } BTP & 5 & 22 & 21 & 22 \\
& 10 & 31 & 23 & 24 \\
& 15 & 10 & 31 & 31 \\
& 30 & 12 & 10 & 10 \\
& Total & 99 & 12 & 12 \\
& 3 & - & 97 & 99 \\
\hline & 5 & 4 & & - \\
BTI & 10 & 5 & 4 & 4 \\
& 15 & 3 & 5 & 5 \\
& 30 & 2 & 3 & 3 \\
& Total & 14 & 2 & 2 \\
BOT & 0.25 & 16 & 14 & 14 \\
& 0.5 & 79 & 16 & 16 \\
& 1 & 84 & 77 & 79 \\
CTZ & Total & 179 & 174 & 84 \\
\hline CCT & 2 & 21 & 21 & 21 \\
\hline All classes & 7 & 22 & 328 & 22 \\
\hline
\end{tabular}


Table 2: Summary statistics of number of repo trades

The table reports summary statistics on the number of trades for repos within an hour on Italian sovereign bonds over the sample period January 4, 2010 to November 30, 2015.

\begin{tabular}{|c|c|c|c|c|c|c|c|c|}
\hline \multicolumn{9}{|c|}{ Panel A: Statistics on the number of repo trades } \\
\hline & Mean & Median & $\mathrm{SD}$ & Kurtosis & Skewness & Range & Min & Max \\
\hline All & 6.577 & 4 & 6.189 & 6.109 & 1.601 & 53 & 1 & 54 \\
\hline CCP-based & 9.701 & 9 & 6.511 & 4.938 & 1.166 & 53 & 1 & 54 \\
\hline Bilateral & 2.536 & 2 & 2.015 & 8.378 & 1.986 & 16 & 1 & 17 \\
\hline
\end{tabular}

\begin{tabular}{|c|c|c|c|c|c|c|}
\hline \multirow[t]{2}{*}{ Time of day } & \multicolumn{3}{|c|}{ Average } & \multicolumn{3}{|c|}{ Standard Deviation } \\
\hline & All Repos & CCP-based & Bilateral & All Repos & CCP-based & Bilateral \\
\hline 8:00 a.m. - 9:00 a.m. & 4.6923 & 4.8570 & 1.4074 & 3.6853 & 3.6977 & 0.6593 \\
\hline 9:00 a.m. $-10: 00$ a.m. & 12.8241 & 15.0327 & 1.9836 & 8.3319 & 7.3729 & 1.3559 \\
\hline 10:00 a.m. $-11: 00$ a.m. & 8.9708 & 10.1700 & 1.6883 & 5.9094 & 5.5049 & 1.0839 \\
\hline 11:00 a.m. -12.00 p.m. & 7.5616 & 8.5953 & 1.4941 & 4.8697 & 4.5036 & 0.8711 \\
\hline 12:00 p.m. - 1:00 p.m. & 3.6961 & 5.3658 & 2.7949 & 2.8228 & 3.0821 & 2.1985 \\
\hline 1:00 p.m. $-2: 00$ p.m. & 2.4609 & & 2.4609 & 1.9814 & & 1.9814 \\
\hline 2:00 p.m. - 3:00 p.m. & 2.9548 & & 2.9548 & 2.3339 & & 2.3339 \\
\hline 3:00 p.m. $-4: 00$ p.m. & 2.6269 & & 2.6269 & 1.89 & & 1.89 \\
\hline Total & 6.577 & 9.701 & 2.536 & 6.189 & 6.511 & 2.015 \\
\hline
\end{tabular}




\section{Table 3: Summary statistics of hourly repo spreads}

The table reports summary statistics on hourly spread for repos (measured in basis points) on Italian sovereign bonds over the sample period January 4, 2010 to November 30, 2015. The repo spread is given by the difference between the ON GC repo rate and the ECB deposit rate. The hourly repo spread is the volume-weighted average of all intraday repo spreads over each hour of the trading day. Panel A shows the general summary statistics for hourly repo spreads; Panel B reports the frequency of the repo spread distribution; and Panel C illustrates average repo spreads by hour-band, type and subsample. In the bilateral repo segment trading during the morning is thin, so the relative statistics are calculated only on a handful of trades. In general, for the CCP segment, the last tradable time is 12:30 p.m. with cut-off time of 12:45 p.m. for the choice of the collaterals. During the ESDC period there are often no trades in the CCP segment during the hourly band 12:00 p.m. $-1: 00$ p.m. *** indicates 1\%; ** 5\%; and * 10\% significance level, respectively.

\begin{tabular}{|c|c|c|c|c|c|c|}
\hline \multicolumn{7}{|c|}{ Panel A: Summary statistics for hourly repo spreads (all sample) } \\
\hline \multicolumn{2}{|c|}{ Repo Clearance } & \multicolumn{2}{|c|}{ CCP-based } & Bilateral & \multicolumn{2}{|c|}{ All Types } \\
\hline \multicolumn{2}{|l|}{ Mean } & \multicolumn{2}{|c|}{16.936} & 19.746 & \multicolumn{2}{|c|}{18.161} \\
\hline \multicolumn{2}{|l|}{ Median } & \multicolumn{2}{|c|}{10.025} & 10.378 & \multicolumn{2}{|c|}{10.107} \\
\hline \multicolumn{2}{|l|}{ Standard Deviation } & \multicolumn{2}{|c|}{20.053} & 23.400 & \multicolumn{2}{|c|}{21.621} \\
\hline \multicolumn{2}{|l|}{ Kurtosis } & \multicolumn{2}{|c|}{10.201} & 7.486 & \multicolumn{2}{|c|}{8.835} \\
\hline \multicolumn{2}{|l|}{ Skewness } & \multicolumn{2}{|c|}{2.409} & 1.976 & \multicolumn{2}{|c|}{2.206} \\
\hline \multicolumn{2}{|l|}{ Range } & \multicolumn{2}{|c|}{159.016} & 175.237 & \multicolumn{2}{|c|}{175.237} \\
\hline \multicolumn{2}{|l|}{ Minimum } & \multicolumn{2}{|c|}{-8.383} & -24.000 & \multicolumn{2}{|c|}{-24.000} \\
\hline \multicolumn{2}{|c|}{ Maximum } & \multicolumn{2}{|c|}{150.633} & 151.237 & \multicolumn{2}{|c|}{151.237} \\
\hline \multicolumn{2}{|c|}{ No. of Collateral Bonds } & \multicolumn{2}{|c|}{335} & 328 & \multicolumn{2}{|c|}{335} \\
\hline \multicolumn{2}{|c|}{ No. of Observations } & \multicolumn{2}{|c|}{5,980} & 4,624 & \multicolumn{2}{|c|}{10,604} \\
\hline \multicolumn{7}{|c|}{ Panel B: Distribution of hourly repo spreads } \\
\hline Hourly Repo Spread & $\mathrm{CCl}$ & -based & & ateral & All & Types \\
\hline (basis points) & No. & $\%$ & No. & $\%$ & No. & $\%$ \\
\hline$(-25,0]$ & 81 & $1.35 \%$ & 140 & $3.03 \%$ & 221 & $2.08 \%$ \\
\hline$(0,25]$ & 4,773 & $79.82 \%$ & 3,316 & $71.71 \%$ & 8,089 & $76.28 \%$ \\
\hline$(25,50]$ & 651 & $10.89 \%$ & 630 & $13.62 \%$ & 1,281 & $12.08 \%$ \\
\hline$(50,75]$ & 322 & $5.38 \%$ & 360 & $7.79 \%$ & 682 & $6.43 \%$ \\
\hline$(75,100]$ & 102 & $1.71 \%$ & 121 & $2.62 \%$ & 223 & $2.10 \%$ \\
\hline$>100$ & 51 & $0.85 \%$ & 57 & $1.23 \%$ & 108 & $1.02 \%$ \\
\hline Total & 5,980 & $100.00 \%$ & 4,624 & $100.00 \%$ & 10,604 & $100.00 \%$ \\
\hline
\end{tabular}

\begin{tabular}{|c|c|c|c|c|c|c|c|c|c|}
\hline Time of day & $\mathrm{CCP}$ & Bil. & Diff. CCP - Bil. & $\mathrm{CCP}$ & Bil. & Diff. CCP - Bil. & $\mathrm{CCP}$ & Bil. & Diff. CCP - Bil. \\
\hline 8:00 a.m. - 9:00 a.m. & 16.45 & 20.231 & $-3.783^{*}$ & 31.8 & 23.162 & $8.641^{*}$ & 11.56 & 8.773 & 2.788 \\
\hline 9:00 a.m. - 10:00 a.m. & 17.97 & 22.822 & $-4.856^{* * *}$ & 30.63 & 24.912 & $5.716^{* * *}$ & 10.9 & 11.899 & -0.996 \\
\hline 12:00 p.m. - 1:00 p.m. & 12.16 & 21.094 & $-8.934 * * *$ & & 28.477 & & 12.16 & 10.538 & $1.623^{* *}$ \\
\hline 1:00 p.m. - 2:00 p.m. & & 19.837 & & & 28.176 & & & 11.177 & \\
\hline 2:00 p.m. - 3:00 p.m. & & 17.694 & & & 27.305 & & & 10.26 & \\
\hline 3:00 p.m. $-4: 00$ p.m. & & 18.27 & & & 26.786 & & & 9.87 & \\
\hline
\end{tabular}




\section{Table 4: Regressions results for model (2) with time-of-day effects}

This table reports the regression results for model (2) of pooled OLS regressions estimated with HAC robust standard errors over the period January 4, 2010 to November 30, 2015. T-statistics are reported in brackets. *** indicates 1\%; ** $5 \%$; and * $10 \%$ significance level, respectively.

\begin{tabular}{|c|c|c|c|}
\hline $\begin{array}{l}\text { Dependent Variable: } \\
\text { GC Hourly Repo Spread }\end{array}$ & All Repos & $\begin{array}{c}\text { CCP-based } \\
\text { Repos }\end{array}$ & $\begin{array}{c}\text { Bilateral } \\
\text { Repos }\end{array}$ \\
\hline \multicolumn{4}{|l|}{ Time-of-day Effects } \\
\hline Constant & $\begin{array}{l}19.769 * * * \\
(15.62)\end{array}$ & $\begin{array}{l}12.023 * * * \\
(11.41)\end{array}$ & $\begin{array}{c}20.527 * * * \\
(13.40)\end{array}$ \\
\hline 8:00 a.m. - 9:00 a.m. & $\begin{array}{l}2.389 * * * \\
(3.33)\end{array}$ & $\begin{array}{c}4.311 * * * \\
(5.43)\end{array}$ & $\begin{array}{l}-0.728 \\
(-0.24)\end{array}$ \\
\hline 9:00 a.m. - 10:00 a.m. & $\begin{array}{c}3.767 * * * \\
(5.25)\end{array}$ & $\begin{array}{l}5.816^{* * *} \\
(6.62)\end{array}$ & $\begin{array}{l}1.651 \\
(1.21)\end{array}$ \\
\hline 10:00 a.m. $-11: 00$ a.m. & $\begin{array}{c}3.428 * * * \\
(4.79)\end{array}$ & $\begin{array}{l}5.287 * * * \\
(6.06)\end{array}$ & $\begin{array}{l}2.010 \\
(1.34)\end{array}$ \\
\hline 11:00 a.m. $-12: 00$ p.m. & $\begin{array}{c}2.976^{* * *} \\
(4.30)\end{array}$ & $\begin{array}{l}4.918 * * * \\
(5.69)\end{array}$ & $\begin{array}{l}1.145 \\
(0.81)\end{array}$ \\
\hline 1:00 p.m. - 2:00 p.m. & $\begin{array}{l}-0.300 \\
(-0.45)\end{array}$ & & $\begin{array}{c}-1.286^{* *} \\
(-2.02)\end{array}$ \\
\hline 2:00 p.m. $-3: 00$ p.m. & $\begin{array}{l}-2.465 * * * \\
(-3.80)\end{array}$ & & $\begin{array}{c}-3.450 * * * \\
(-5.64)\end{array}$ \\
\hline 3:00 p.m. - 4:00 p.m. & $\begin{array}{c}-1.897 * * * \\
(-2.84)\end{array}$ & & $\begin{array}{c}-2.877 * * * \\
(-4.58)\end{array}$ \\
\hline $\mathrm{CCP}$ & $\begin{array}{c}-6.109 * * * \\
(-4.35) \\
\end{array}$ & & \\
\hline Seasonal Controls & Yes & Yes & Yes \\
\hline Observations & 10,604 & 5,980 & 4,624 \\
\hline Adj. $R^{2}$ & 0.0415 & 0.0344 & 0.0419 \\
\hline
\end{tabular}




\section{Table 5: Summary statistics for explanatory variables}

The table presents the summary statistics for all independent variables over the aggregate repo sample (Panel A) and separately for CCP-based repos (Panel B) and bilaterally-traded repos (Period C) over the period that goes from January 4, 2010 to November, 30 2015. Bond Supply is measured by the portfolio-weighted hourly average of the sum of outstanding notional of bonds available for purchase at the top three levels of the ask-side (the measurement unit is millions of euros). Bond BAS is the portfolio-weighted hourly average bond bid-ask spread (measured in basis points). Bond Mod. Duration is measured by the portfolio-weighted hourly average bond modified duration. Repo Net Order Flow is equal to the hourly difference between GC repo volume and GC reverse repo volumes (measured in millions of euros). Repo Trades is the total number of hourly repo transactions. Repo Volatility is measured by the standard deviation of repo rates for each hour over a rolling window of 22 days. EL is the total excess liquidity deposited daily at the ECB facility and it is computed as the credit institutions' current account holdings, plus funds in the ECB deposit facility minus reserve requirements (the measurement unit is billions of euros). Margin Costs (measured in percentage) is the initial margin required by the Italian central counterparties for the Italian sovereign bonds for a duration ranging from 3.25 to 4.75 years. The Excess Bank CDS (measured in basis points) is the average difference between banks' daily (senior five-year euro-denominated) CDS premium and the five-year euro-denominated Italian CDS premium obtained from Bloomberg. The average measure is weighted by the market capitalisation of the Italian banks.

\begin{tabular}{|c|c|c|c|c|c|c|c|c|c|}
\hline \multicolumn{10}{|l|}{ Panel A: All Repos } \\
\hline Variables & Obs. & Mean & Median & SD & Kurtosis & Skewness & Range & Min & Max \\
\hline Bond Supply (€ M) & 10,604 & 47.720 & 46.946 & 15.917 & 2.358 & 0.086 & 98.924 & 1.281 & 100.205 \\
\hline Bond BAS & 10,604 & 26.093 & 15.082 & 28.222 & 13.836 & 2.854 & 259.046 & 0.110 & 259.156 \\
\hline Bond Mod. Duration & 10,604 & 3.979 & 4.073 & 0.770 & 2.844 & -0.277 & 5.713 & 0.161 & 5.874 \\
\hline Repo Net Order Flow ( $€$ M) & 10,604 & -140.300 & -66.000 & 747.979 & 7.366 & -0.461 & $10,442.500$ & $-4,730.500$ & $5,712.000$ \\
\hline Repo Trades & 10,604 & 6.577 & 4.000 & 6.189 & 6.109 & 1.601 & 53.000 & 1.000 & 54.000 \\
\hline Repo Volatility & 10,604 & 5.495 & 4.212 & 4.628 & 14.806 & 2.976 & 36.535 & 0.903 & 37.438 \\
\hline $\mathrm{EL}(€ \mathrm{~B})$ & 10,604 & 270.085 & 198.395 & 228.730 & 2.870 & 0.960 & 909.432 & -96.221 & 813.211 \\
\hline \multicolumn{10}{|l|}{ Panel B: CCP-based Repos } \\
\hline Variables & Obs. & Mean & Median & SD & Kurtosis & Skewness & Range & Min & Max \\
\hline Bond Supply (€ M) & 5,980 & 47.998 & 48.195 & 16.989 & 2.178 & -0.037 & 98.924 & 1.281 & 100.205 \\
\hline Bond BAS & 5,980 & 27.047 & 14.889 & 28.941 & 11.618 & 2.597 & 226.098 & 0.139 & 226.237 \\
\hline Bond Mod. Duration & 5,980 & 3.938 & 4.055 & 0.611 & 3.123 & -0.216 & 5.346 & 0.161 & 5.507 \\
\hline Repo Net Order Flow ( $€$ M) & 5,980 & -183.755 & -125.000 & 924.350 & 5.238 & -0.253 & $10,442.500$ & $-4,730.500$ & $5,712.000$ \\
\hline Repo Trades & 5,980 & 9.701 & 9.000 & 6.511 & 4.938 & 1.166 & 53.000 & 1.000 & 54.000 \\
\hline Repo Volatility & 5,980 & 4.889 & 3.616 & 4.106 & 15.736 & 3.105 & 29.920 & 0.903 & 30.823 \\
\hline $\mathrm{EL}(€ \mathrm{~B})$ & 5,980 & 285.173 & 209.743 & 226.685 & 2.688 & 0.885 & 909.432 & -96.221 & 813.211 \\
\hline \multicolumn{10}{|l|}{ Panel C: Bilateral Repos } \\
\hline Variables & Obs. & Mean & Median & SD & Kurtosis & Skewness & Range & Min & Max \\
\hline Bond Supply (€ M) & 4,624 & 47.361 & 45.875 & 14.407 & 2.641 & 0.316 & 92.061 & 3.078 & 95.139 \\
\hline Bond BAS & 4,624 & 24.858 & 15.238 & 27.219 & 17.477 & 3.242 & 259.046 & 0.110 & 259.156 \\
\hline Bond Mod. Duration & 4,624 & 4.032 & 4.139 & 0.934 & 2.323 & -0.375 & 5.708 & 0.166 & 5.874 \\
\hline Repo Net Order Flow ( $€$ M) & 4,624 & -84.102 & -50.000 & 415.364 & 10.018 & -0.977 & $5,806.000$ & $-3,341.000$ & $2,465.000$ \\
\hline Repo Trades & 4,624 & 2.536 & 2.000 & 2.015 & 8.378 & 1.986 & 16.000 & 1.000 & 17.000 \\
\hline Repo Volatility & 4,624 & 6.278 & 4.917 & 5.122 & 13.288 & 2.802 & 36.313 & 1.125 & 37.438 \\
\hline $\mathrm{EL}(€ \mathrm{~B})$ & 4,624 & 250.572 & 185.172 & 229.908 & 3.166 & 1.078 & 909.432 & -96.221 & 813.211 \\
\hline
\end{tabular}


Table 6: Pearson correlation matrixes for the aggregate sample, the CCP-based repo and the bilateral repo samples

Correlation matrix of dependent and independent variables for the aggregate repo sample (Panel A) and separately for CCP-based repos (Panel B) and bilaterally traded repos (Panel C) over the period that goes from January 4, 2010 to November 30, 2015. Variable definitions and measurements are explained in Table 5. *** indicates $1 \%$; ** 5\%; and * $10 \%$ significance level, respectively.

\begin{tabular}{|c|c|c|c|c|c|c|c|c|c|}
\hline \multicolumn{10}{|l|}{ Panel A: All Repos } \\
\hline \multirow{2}{*}{ Variable } & GC Hourly & Bond & Bond & Bond & Repo & Repo & Repo & \multirow{2}{*}{ EL } & Margin \\
\hline & Repo Spread & Supply & BAS & Mod. Duration & Net Order Flow & Trades & Volatility & & Costs \\
\hline Bond Supply & $0.022 * *$ & & & & & & & & \\
\hline Bond BAS & $0.176 * * *$ & $-0.592 * * *$ & & & & & & & \\
\hline Bond Mod. Duration & $0.203 * * *$ & $-0.077 * * *$ & $0.077 * * *$ & & & & & & \\
\hline Repo Net Order Flow & $0.068 * * *$ & $0.075 * * *$ & $-0.026 * * *$ & $-0.046 * * *$ & & & & & \\
\hline Repo Trades & $0.029 * * *$ & $0.231 * * *$ & $-0.081 * * *$ & -0.010 & $-0.122 * * *$ & & & & \\
\hline Repo Volatility & $0.441 * * *$ & $-0.223 * * *$ & $0.627 * * *$ & $0.097 * * *$ & -0.005 & $-0.071 * * *$ & & & \\
\hline EL & $-0.464 * * *$ & $-0.11 * * *$ & $0.115^{* * *}$ & $-0.59 * * *$ & $0.046 * * *$ & $-0.026 * *$ & $-0.213 * * *$ & & \\
\hline Margin Costs & $-0.213 * * *$ & $0.161 * * *$ & $0.09 * * *$ & $-0.722 * * *$ & $0.059 * * *$ & $0.152 * * *$ & $0.052 * * *$ & $0.557 * * *$ & \\
\hline Excess Bank CDS & 0.014 & $-0.061 * * *$ & $0.196 * * *$ & $-0.562 * * *$ & $0.06 * * *$ & 0.008 & $0.192 * * *$ & $0.533 * * *$ & $0.661 * * *$ \\
\hline \multicolumn{10}{|c|}{ Panel B: CCP-based Repos } \\
\hline \multirow{2}{*}{ Variable } & GC Hourly & Bond & Bond & Bond & Repo & Repo & Repo & \multirow{2}{*}{ EL } & Margin \\
\hline & Repo Spread & Supply & BAS & Mod. Duration & Net Order Flow & Trades & Volatility & & Costs \\
\hline Bond Supply & $-0.049 * * *$ & & & & & & & & \\
\hline Bond BAS & $0.197 * * *$ & $-0.633 * * *$ & & & & & & & \\
\hline Bond Mod. Duration & $0.098 * * *$ & $0.068 * * *$ & $-0.044 * * *$ & & & & & & \\
\hline Repo Net Order Flow & $0.078 * * *$ & $0.082 * * *$ & $-0.025^{*}$ & $-0.038 * * *$ & & & & & \\
\hline Repo Trades & $0.066^{* * *}$ & $0.366 * * *$ & $-0.178 * * *$ & $-0.042 * * *$ & $-0.086 * * *$ & & & & \\
\hline Repo Volatility & $0.481 * * *$ & $-0.241 * * *$ & $0.599 * * *$ & -0.020 & -0.020 & 0.003 & & & \\
\hline EL & $-0.471 * * *$ & $-0.109 * * *$ & $0.147 * * *$ & $-0.527 * * *$ & $0.043 * * *$ & $-0.062 * * *$ & $-0.228 * * *$ & & \\
\hline Margin Costs & $-0.231 * * *$ & $0.153 * * *$ & $0.067 * * *$ & $-0.713 * * *$ & $0.065 * * *$ & $0.163 * * *$ & 0.001 & $0.503 * * *$ & \\
\hline Excess Bank CDS & -0.018 & $-0.123 * * *$ & $0.222 * * *$ & $-0.65 * * *$ & $0.063 * * *$ & -0.014 & $0.158 * * *$ & $0.537 * * *$ & $0.636 * * *$ \\
\hline \multicolumn{10}{|c|}{ Panel C: Bilateral Repos } \\
\hline \multirow{2}{*}{ Variable } & Hourly & Bond & Bond & Bond & Repo & Repo & Repo & \multirow{2}{*}{ EL } & Margin \\
\hline & Repo Spread & Supply & BAS & Mod. Duration & Net Order Flow & Trades & Volatility & & Costs \\
\hline Bond Supply & $0.118 * * *$ & & & & & & & & \\
\hline Bond BAS & $0.16^{* * *}$ & $-0.53 * * *$ & & & & & & & \\
\hline Bond Mod. Duration & $0.277 * * *$ & $-0.227 * * *$ & $0.195 * * *$ & & & & & & \\
\hline Repo Net Order Flow & $0.053 * * *$ & $0.067 * * *$ & $-0.025^{*}$ & $-0.098 * * *$ & & & & & \\
\hline Repo Trades & $0.196 * * *$ & $-0.093 * * *$ & $0.04 * * *$ & $0.259 * * *$ & $-0.267 * * *$ & & & & \\
\hline Repo Volatility & $0.398 * * *$ & $-0.21 * * *$ & $0.701 * * *$ & $0.164 * * *$ & -0.011 & $0.081 * * *$ & & & \\
\hline EL & $-0.453 * * *$ & $-0.118 * * *$ & $0.067 * * *$ & $-0.661 * * *$ & $0.086 * * *$ & $-0.226 * * *$ & $-0.184 * * *$ & & \\
\hline Margin Costs & $-0.18 * * *$ & $0.175 * * *$ & $0.106 * * *$ & $-0.745^{* * *}$ & $0.115 * * *$ & $-0.283^{* * *}$ & $0.155^{* * *}$ & $0.614 * * *$ & \\
\hline Excess Bank CDS & $0.055 * * *$ & $0.026 *$ & $0.158 * * *$ & $-0.507 * * *$ & $0.083 * * *$ & $-0.101 * * *$ & $0.248 * * *$ & $0.525 * * *$ & $0.695 * * *$ \\
\hline
\end{tabular}


Table 7: Collateral and repo factors - Pooled regressions results for model (5)

This table reports the regression results for model (5) of pooled OLS regressions estimated with HAC robust standard errors over the period January 4, 2010 to November 30,2015 . The dependent variable is the GC Hourly Repo Spread. Variable definitions and measurements are explained at Table 5. Repo Net Order Flow is measured here in billions of euros. EL ${ }^{2}$ is rescaled over 1,000. T-statistics are reported in brackets. *** indicates 1\%; ** 5\%; and * 10\% significance level, respectively. All explanatory variables are lagged by one hour.

\begin{tabular}{|c|c|c|c|c|c|c|c|c|c|c|c|c|}
\hline \multirow[b]{3}{*}{ Constant } & \multicolumn{4}{|c|}{ All Repos } & \multicolumn{4}{|c|}{ CCP-based Repos } & \multicolumn{4}{|c|}{ Bilateral Repos } \\
\hline & (1) & (2) & (3) & (4) & (5) & (6) & (7) & (8) & (9) & (10) & (11) & $(12)$ \\
\hline & $\begin{array}{l}-24.833 * * * \\
(-9.14)\end{array}$ & $\begin{array}{l}-6.857 * * * \\
(-3.32)\end{array}$ & $\begin{array}{l}-26.121 * * * \\
(-1076)\end{array}$ & $\begin{array}{l}18.707 * * * \\
(8.60)\end{array}$ & $\begin{array}{l}-17.376^{* * * *} \\
(-4.19)\end{array}$ & $\begin{array}{l}-10.917 * * * \\
(-3.20)\end{array}$ & $\begin{array}{l}-22.067 * * * \\
(-6.58)\end{array}$ & $\begin{array}{l}19.835 \text { **** } \\
(7.65)\end{array}$ & $\begin{array}{l}-41.524 * * * \\
(-9.87)\end{array}$ & $\begin{array}{l}-8.586 * * * \\
(-3.20)\end{array}$ & $\begin{array}{l}-39.264 * * * \\
(-10.13)\end{array}$ & $\begin{array}{l}14.001 \text { *** } \\
(3.81)\end{array}$ \\
\hline Lag Bond Supply & $\begin{array}{l}0.323 * * * \\
(8.65)\end{array}$ & & $\begin{array}{l}0.232 * * * \\
(7.89)\end{array}$ & $\begin{array}{l}0.157 * * * \\
(5.75)\end{array}$ & $\begin{array}{l}0.181 * * * \\
(4.07)\end{array}$ & & $\begin{array}{l}0.123 * * * \\
(3.75)\end{array}$ & $\begin{array}{l}0.106^{* * * *} \\
(3.72)\end{array}$ & $\begin{array}{l}0.544 * * * \\
(8.96)\end{array}$ & & $\begin{array}{l}0.439 * * * * \\
(8.65)\end{array}$ & $\begin{array}{l}0.234 * * * \\
(4.58)\end{array}$ \\
\hline Lag Bond BAS & $\begin{array}{l}0.218 * * * \\
(7.27)\end{array}$ & $\begin{array}{l}0.132 * * * \\
(4.85)\end{array}$ & & $\begin{array}{l}0.046 \\
(1.53)\end{array}$ & $\begin{array}{l}0.189^{* * * *} \\
(4.81)\end{array}$ & $\begin{array}{l}0.147 * * * \\
(4.26)\end{array}$ & & $\begin{array}{l}0.054 \\
(1.52)\end{array}$ & $\begin{array}{l}0.239 * * * \\
(5.18)\end{array}$ & $\begin{array}{l}0.097 * * \\
(2.11)\end{array}$ & & $\begin{array}{l}0.024 \\
(0.41)\end{array}$ \\
\hline Lag Bond Mod. Duration & $\begin{array}{l}5.366 * * * \\
(9.28)\end{array}$ & $\begin{array}{l}5.210 * * * \\
(8.65)\end{array}$ & $\begin{array}{l}4.781 * * * * \\
(9.47)\end{array}$ & & $\begin{array}{l}3.673 * * * \\
(4.32)\end{array}$ & $\begin{array}{l}4.153^{* * * *} \\
(4.96)\end{array}$ & $\begin{array}{l}3.845 * * * \\
(5.65)\end{array}$ & & $\begin{array}{l}7.274 * * * \\
(9.21)\end{array}$ & $\begin{array}{l}5.586 * * * \\
(6.64)\end{array}$ & $\begin{array}{l}5.792 * * * \\
(8.23)\end{array}$ & \\
\hline Lag Repo Net Order Flows & & $\begin{array}{l}2.396 \text { *** } \\
(5.57)\end{array}$ & $\begin{array}{l}2.097 * * * \\
(5.31)\end{array}$ & $\begin{array}{l}2.110^{* * * *} \\
(6.34)\end{array}$ & & $\begin{array}{l}2.167 * * * \\
(4.62)\end{array}$ & $\begin{array}{l}2.124 * * * \\
(4.98)\end{array}$ & $\begin{array}{l}2.141 \text { *** } \\
(5.99)\end{array}$ & & $\begin{array}{l}5.341^{* * * *} \\
(4.96)\end{array}$ & $\begin{array}{l}4.245^{* * * *} \\
(4.58)\end{array}$ & $\begin{array}{l}2.939 \text { *** } \\
(3.60)\end{array}$ \\
\hline Lag Repo Trades & & $\begin{array}{l}0.428 * * * \\
(7.58)\end{array}$ & $\begin{array}{l}0.144 * * * \\
(2.80)\end{array}$ & $\begin{array}{l}0.098^{* *} \\
(2.31)\end{array}$ & & $\begin{array}{l}0.350 \text { *** } \\
(5.79)\end{array}$ & $\begin{array}{l}0.161 \text { *** } \\
(2.77)\end{array}$ & $\begin{array}{l}0.132 * * * \\
(2.81)\end{array}$ & & $\begin{array}{l}1.737 * * * \\
(7.19)\end{array}$ & $\begin{array}{l}1.600^{* * * *} \\
(7.36)\end{array}$ & $\begin{array}{l}0.713 * * * \\
(3.94)\end{array}$ \\
\hline Lag Repo Volatility & & & $\begin{array}{l}2.138 * * * \\
(12.01)\end{array}$ & $\begin{array}{l}1.639 * * * \\
(10.37)\end{array}$ & & & $\begin{array}{l}2.445 * * * \\
(9.29)\end{array}$ & $\begin{array}{l}1.698 * * * \\
(7.55)\end{array}$ & & & $\begin{array}{l}1.839 * * * \\
(8.36)\end{array}$ & $\begin{array}{l}1.651 \text { **** } \\
(6.86)\end{array}$ \\
\hline $\mathrm{CCP}$ & $\begin{array}{l}-5.803 * * * \\
(-4.43)\end{array}$ & $\begin{array}{l}-6.993 * * * \\
(-4.82)\end{array}$ & $\begin{array}{l}-3.314 * * \\
(-2.56)\end{array}$ & $\begin{array}{l}-0.553 \\
(-0.51)\end{array}$ & & & & & & & & \\
\hline Lag EL & & & & $\begin{array}{l}-0.141 \text { **** } \\
(-17.61)\end{array}$ & & & & $\begin{array}{l}-0.136^{* * *} \\
(-13.25)\end{array}$ & & & & $\begin{array}{l}-0.138^{* * *} \\
(-11.09)\end{array}$ \\
\hline Lag EL ${ }^{2}$ & & & & $\begin{array}{l}0.139^{* * *} \\
(15.65)\end{array}$ & & & & $\begin{array}{l}0.132 * * * \\
(11.70)\end{array}$ & & & & $\begin{array}{l}0.138^{* * * *} \\
(9.99)\end{array}$ \\
\hline 8:00 a.m. - 9:00 a.m. & $\begin{array}{l}4.227 * * * \\
(6.04)\end{array}$ & $\begin{array}{l}3.960 \text { *** } \\
(5.48)\end{array}$ & $\begin{array}{l}3.373 * * * \\
(5.50)\end{array}$ & $\begin{array}{l}2.325 * * * \\
(4.17)\end{array}$ & $\begin{array}{l}5.892 * * * \\
(6.94)\end{array}$ & $\begin{array}{l}5.726 \text { *** } \\
(7.17)\end{array}$ & $\begin{array}{l}4.173 \text { *** } \\
(5.54)\end{array}$ & $\begin{array}{l}2.238 \text { *** } \\
(4.14)\end{array}$ & $\begin{array}{l}-0.159 \\
(-0.06)\end{array}$ & $\begin{array}{l}-4.796 \\
(-1.59)\end{array}$ & $\begin{array}{l}-1.307 \\
(-0.55)\end{array}$ & $\begin{array}{l}1.282 \\
(0.60)\end{array}$ \\
\hline 9:00 a.m. - 10:00 a.m. & $\begin{array}{l}6.008 * * * \\
(6.42)\end{array}$ & $\begin{array}{l}2.329 * * * \\
(2.72)\end{array}$ & $\begin{array}{l}7.761 * * * \\
(9.41)\end{array}$ & $\begin{array}{l}4.165 * * * \\
(6.15)\end{array}$ & $\begin{array}{l}5.905 * * * \\
(4.27)\end{array}$ & $\begin{array}{l}3.821 \text { *** } \\
(3.10)\end{array}$ & $\begin{array}{l}7.009 * * * \\
(5.94)\end{array}$ & $\begin{array}{l}3.387 * * * \\
(4.24)\end{array}$ & $\begin{array}{l}1.180 \\
(0.91)\end{array}$ & $\begin{array}{l}-2.975^{* *} \\
(-2.17)\end{array}$ & $\begin{array}{l}0.242 \\
(0.20)\end{array}$ & $\begin{array}{l}0.949 \\
(0.86)\end{array}$ \\
\hline 10:00 a.m. - 11:00 a.m. & $\begin{array}{l}3.193 * * * \\
(4.47)\end{array}$ & $\begin{array}{l}0.286 \\
(0.34)\end{array}$ & $\begin{array}{l}2.840 * * * \\
(3.81)\end{array}$ & $\begin{array}{l}1.328^{* * *} \\
(2.18)\end{array}$ & $\begin{array}{l}4.890^{* * * *} \\
(5.05)\end{array}$ & $\begin{array}{l}2.368 * * \\
(2.01)\end{array}$ & $\begin{array}{l}2.780 \text { *** } \\
(2.80)\end{array}$ & $\begin{array}{l}0.659 \\
(1.02)\end{array}$ & $\begin{array}{l}-0.159 \\
(-0.11)\end{array}$ & $\begin{array}{l}-2.715^{*} \\
(-1.78)\end{array}$ & $\begin{array}{l}1.515 \\
(1.06)\end{array}$ & $\begin{array}{l}1.529 \\
(1.26)\end{array}$ \\
\hline 11:00 a.m. - 12:00 p.m. & $\begin{array}{l}3.294 * * * \\
(4.91)\end{array}$ & $\begin{array}{l}1.904 * * * \\
(2.74)\end{array}$ & $\begin{array}{l}2.019 * * * \\
(3.32)\end{array}$ & $\begin{array}{l}0.781 \\
(1.59)\end{array}$ & $\begin{array}{l}5.316 \text { **** } \\
(5.80)\end{array}$ & $\begin{array}{l}4.032 * * * \\
(4.31)\end{array}$ & $\begin{array}{l}2.534 * * * \\
(3.09)\end{array}$ & $\begin{array}{l}0.539 \\
(1.07)\end{array}$ & $\begin{array}{l}-2.382^{*} \\
(-1.75)\end{array}$ & $\begin{array}{l}-2.762 * * \\
(-2.01)\end{array}$ & $\begin{array}{l}-1.639 \\
(-1.31)\end{array}$ & $\begin{array}{l}-0.139 \\
(-0.13)\end{array}$ \\
\hline 1:00 p.m. $-2: 00$ p.m. & $\begin{array}{l}1.037^{*} \\
(1.65)\end{array}$ & $\begin{array}{l}0.683 \\
(1.07)\end{array}$ & $\begin{array}{l}0.589 \\
(1.01)\end{array}$ & $\begin{array}{l}-0.083 \\
(-0.16)\end{array}$ & & & & & $\begin{array}{l}-1.283^{*} \\
(-1.94)\end{array}$ & $\begin{array}{l}-1.376^{* *} \\
(-1.98)\end{array}$ & $\begin{array}{l}-2.168 * * * * \\
(-3.29)\end{array}$ & $\begin{array}{l}-0.826 \\
(-1.52)\end{array}$ \\
\hline 2:00 p.m. - 3:00 p.m. & $\begin{array}{l}-0.026 \\
(-0.04)\end{array}$ & $\begin{array}{l}-0.334 \\
(-0.55)\end{array}$ & $\begin{array}{l}-0.230 \\
(-0.42)\end{array}$ & $\begin{array}{l}-0.187 \\
(-0.38)\end{array}$ & & & & & $\begin{array}{l}-2.125 * * * \\
(-3.47)\end{array}$ & $\begin{array}{l}-2.061 * * * \\
(-3.22)\end{array}$ & $\begin{array}{l}-2.637 * * * \\
(-4.49)\end{array}$ & $\begin{array}{l}-0.890^{*} \\
(-1.81)\end{array}$ \\
\hline 3:00 p.m. - 4:00 p.m. & $\begin{array}{l}0.286 \\
(0.46)\end{array}$ & $\begin{array}{l}-0.528 \\
(-0.81)\end{array}$ & $\begin{array}{l}-0.274 \\
(-0.47)\end{array}$ & $\begin{array}{l}-0.443 \\
(-0.84)\end{array}$ & & & & & $\begin{array}{l}-1.731 \text { *** } \\
(-2.71)\end{array}$ & $\begin{array}{l}-3.083 * * * \\
(-4.13)\end{array}$ & $\begin{array}{l}-3.375 * * * \\
(-4.89)\end{array}$ & $\begin{array}{l}-1.388 * * \\
(-2.42)\end{array}$ \\
\hline Seasonal Controls & $\mathrm{Y}$ & $\mathrm{Y}$ & $\mathrm{Y}$ & $\mathrm{Y}$ & $\mathrm{Y}$ & $\mathrm{Y}$ & $\mathrm{Y}$ & $\mathrm{Y}$ & $\mathrm{Y}$ & $\mathrm{Y}$ & $\mathrm{Y}$ & $\mathrm{Y}$ \\
\hline Observations & 10,602 & 10,602 & 10,602 & 10,602 & 5,979 & 5,979 & 5,979 & 5,979 & 4,623 & 4,623 & 4,623 & 4,623 \\
\hline Adj. $R^{2}$ & 0.132 & 0.114 & 0.280 & 0.476 & 0.0872 & 0.0936 & 0.287 & 0.500 & 0.205 & 0.149 & 0.325 & 0.457 \\
\hline
\end{tabular}




\section{Table 8: Collateral and repo factors - Pooled regression results for model (5) over two sub-periods}

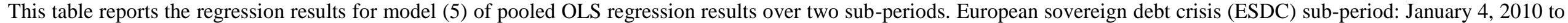

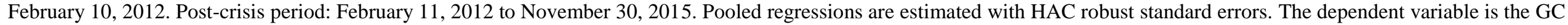

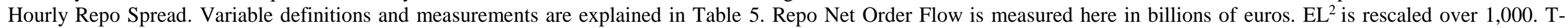
statistics are reported in brackets. $* * *$ indicates $1 \% ; * * 5 \%$; and $* 10 \%$ significance level, respectively. All explanatory variables are lagged by one hour.

\begin{tabular}{|c|c|c|c|c|c|c|c|c|c|c|c|c|}
\hline \multirow{3}{*}{ Period } & \multicolumn{4}{|c|}{ All Repos } & \multicolumn{4}{|c|}{ CCP-based Repos } & \multicolumn{4}{|c|}{ Bilateral Repos } \\
\hline & \multicolumn{2}{|c|}{ ESDC } & \multicolumn{2}{|c|}{ Post-Crisis } & \multicolumn{2}{|c|}{ ESDC } & \multicolumn{2}{|c|}{ Post-Crisis } & \multicolumn{2}{|c|}{ ESDC } & \multicolumn{2}{|c|}{ Post-Crisis } \\
\hline & (1) & (2) & (3) & (4) & (5) & (6) & (7) & (8) & (9) & $(10)$ & $(11)$ & (12) \\
\hline Constant & $\begin{array}{l}4.064 \\
(1.26)\end{array}$ & $\begin{array}{l}-0.082 \\
(-0.02)\end{array}$ & $\begin{array}{l}28.135 * * * \\
(19.07)\end{array}$ & $\begin{array}{l}27.928 * * * \\
(18.83)\end{array}$ & $\begin{array}{l}\text { 6.540* } \\
(1.67)\end{array}$ & $\begin{array}{l}1.797 \\
(0.41)\end{array}$ & $\begin{array}{l}25.919 \text { *** } \\
(13.71)\end{array}$ & $\begin{array}{l}25.733 \text { *** } \\
(13.16)\end{array}$ & $\begin{array}{l}2.882 \\
(0.61)\end{array}$ & $\begin{array}{l}0.071 \\
(0.01)\end{array}$ & $\begin{array}{l}29.966 \text { *** } \\
(15.68)\end{array}$ & $\begin{array}{l}28.908 \text { *** } \\
(14.22)\end{array}$ \\
\hline $\begin{array}{l}\text { Lag Bond Supply } \\
\text { Lag Bond BAS }\end{array}$ & $\begin{array}{l}0.452 * * * \\
(8.48)\end{array}$ & $\begin{array}{l}0.545 * * * \\
(8.58) \\
0.098^{* *} \\
(2.28)\end{array}$ & $\begin{array}{l}-0.069 * * * \\
(-4.93)\end{array}$ & $\begin{array}{l}-0.066 * * * \\
(-4.61) \\
0.007 \\
(0.61)\end{array}$ & $\begin{array}{l}0.408 * * * \\
(5.68)\end{array}$ & $\begin{array}{l}0.534 * * * \\
(6.44) \\
0.111 * * \\
(2.02)\end{array}$ & $\begin{array}{l}-0.058^{* * * *} \\
(-2.91)\end{array}$ & $\begin{array}{l}-0.055 * * * \\
(-2.65) \\
0.004 \\
(0.38)\end{array}$ & $\begin{array}{l}0.496 \text { *** } \\
(6.46)\end{array}$ & $\begin{array}{l}0.552 * * * \\
(5.79) \\
0.066 \\
(0.91)\end{array}$ & $\begin{array}{l}-0.087 * * * \\
(-4.79)\end{array}$ & $\begin{array}{l}-0.075 * * * \\
(-4.15) \\
0.064 \\
(1.53)\end{array}$ \\
\hline Lag Repo Net Order Flows & $\begin{array}{l}3.953 * * * \\
(6.25)\end{array}$ & $\begin{array}{l}3.827 * * * \\
(6.22)\end{array}$ & $\begin{array}{l}0.612 * * * \\
(4.32)\end{array}$ & $\begin{array}{l}0.614 * * * \\
(4.32)\end{array}$ & $\begin{array}{l}4.083 * * * \\
(5.43)\end{array}$ & $\begin{array}{l}3.896 * * * \\
(5.40)\end{array}$ & $\begin{array}{l}0.662 * * * \\
(4.57)\end{array}$ & $\begin{array}{l}0.663 * * * \\
(4.57)\end{array}$ & $\begin{array}{l}3.108 * * * \\
(3.35)\end{array}$ & $\begin{array}{l}3.161 * * * \\
(3.41)\end{array}$ & $\begin{array}{l}-0.923 \\
(-1.17)\end{array}$ & $\begin{array}{l}-0.887 \\
(-1.11)\end{array}$ \\
\hline Lag Repo Trades & $\begin{array}{l}0.426 * * * \\
(3.46)\end{array}$ & $\begin{array}{l}0.418^{* * * *} \\
(3.41)\end{array}$ & $\begin{array}{l}0.123^{* * * *} \\
(5.08)\end{array}$ & $\begin{array}{l}0.124 * * * \\
(5.14)\end{array}$ & $\begin{array}{l}0.540 * * * \\
(3.60)\end{array}$ & $\begin{array}{l}0.523 * * * \\
(3.57)\end{array}$ & $\begin{array}{l}0.113^{* * * *} \\
(4.60)\end{array}$ & $\begin{array}{l}0.113^{* * * *} \\
(4.61)\end{array}$ & $\begin{array}{l}0.275 \\
(1.28)\end{array}$ & $\begin{array}{l}0.310 \\
(1.43)\end{array}$ & $\begin{array}{l}0.537 * * * \\
(3.72)\end{array}$ & $\begin{array}{l}0.539 * * * \\
(3.72)\end{array}$ \\
\hline Lag Repo Volatility & $\begin{array}{l}1.903 * * * \\
(11.83)\end{array}$ & $\begin{array}{l}1.544 * * * \\
(7.60)\end{array}$ & $\begin{array}{l}0.945^{* * * *} \\
(6.84)\end{array}$ & $\begin{array}{l}0.942 * * * \\
(6.79)\end{array}$ & $\begin{array}{l}2.052 * * * \\
(9.16)\end{array}$ & $\begin{array}{l}1.572 * * * \\
(5.52)\end{array}$ & $\begin{array}{l}1.200 * * * \\
(5.91)\end{array}$ & $\begin{array}{l}1.199 * * * \\
(5.89)\end{array}$ & $\begin{array}{l}1.840 * * * \\
(8.67)\end{array}$ & $\begin{array}{l}1.619^{* * * *} \\
(5.73)\end{array}$ & $\begin{array}{l}0.501 * * * \\
(3.34)\end{array}$ & $\begin{array}{l}0.461 * * * \\
(3.11)\end{array}$ \\
\hline $\mathrm{CCP}$ & $\begin{array}{l}1.621 \\
(0.96)\end{array}$ & $\begin{array}{l}1.321 \\
(0.79)\end{array}$ & $\begin{array}{l}-0.896 \\
(-1.46)\end{array}$ & $\begin{array}{l}-0.939 \\
(-1.49)\end{array}$ & & & & & & & & \\
\hline Lag EL & $\begin{array}{l}-0.121 * * * \\
(-7.24)\end{array}$ & $\begin{array}{l}-0.122 * * * \\
(-7.34)\end{array}$ & $\begin{array}{l}-0.093 * * * \\
(-22.51)\end{array}$ & $\begin{array}{l}-0.093 * * * \\
(-22.48)\end{array}$ & $\begin{array}{l}-0.105 * * * \\
(-4.65)\end{array}$ & $\begin{array}{l}-0.110 * * * \\
(-4.98)\end{array}$ & $\begin{array}{l}-0.092 * * * \\
(-17.72)\end{array}$ & $\begin{array}{l}-0.091 * * * \\
(-17.70)\end{array}$ & $\begin{array}{l}-0.131 * * * \\
(-5.49)\end{array}$ & $\begin{array}{l}-0.130 * * * \\
(-5.39)\end{array}$ & $\begin{array}{l}-0.093 * * * \\
(-13.80)\end{array}$ & $\begin{array}{l}-0.092 * * * \\
(-13.71)\end{array}$ \\
\hline Lag EL ${ }^{2}$ & $\begin{array}{l}0.086^{* *} \\
(2.55) \\
\end{array}$ & $\begin{array}{l}0.080 * * \\
(2.35) \\
\end{array}$ & $\begin{array}{l}0.085 * * * \\
(18.61) \\
\end{array}$ & $\begin{array}{l}0.085^{* * *} \\
(18.58) \\
\end{array}$ & $\begin{array}{l}0.026 \\
(0.55) \\
\end{array}$ & $\begin{array}{l}0.032 \\
(0.70) \\
\end{array}$ & $\begin{array}{l}0.084 * * * \\
(14.33) \\
\end{array}$ & $\begin{array}{l}0.084 * * * \\
(14.33) \\
\end{array}$ & $\begin{array}{l}0.129 * * * \\
(2.78) \\
\end{array}$ & $\begin{array}{l}0.120^{* *} \\
(2.44) \\
\end{array}$ & $\begin{array}{l}0.083 * * * \\
(11.75) \\
\end{array}$ & $\begin{array}{l}0.080 \text { *** } \\
(11.39) \\
\end{array}$ \\
\hline Seasonal Controls & $\mathrm{Y}$ & $\mathrm{Y}$ & $\mathrm{Y}$ & $\mathrm{Y}$ & $\mathrm{Y}$ & $\mathrm{Y}$ & $\mathrm{Y}$ & $\mathrm{Y}$ & $\mathrm{Y}$ & $\mathrm{Y}$ & $\mathrm{Y}$ & $\mathrm{Y}$ \\
\hline Time-of-Day Effects & $\mathrm{Y}$ & $\mathrm{Y}$ & $\mathrm{Y}$ & $\mathrm{Y}$ & $\mathrm{Y}$ & $\mathrm{Y}$ & $\mathrm{Y}$ & $\mathrm{Y}$ & $\mathrm{Y}$ & $\mathrm{Y}$ & $\mathrm{Y}$ & $\mathrm{Y}$ \\
\hline Observations & 4,446 & 4,446 & 6,156 & 6,156 & 1,858 & 1,858 & 4,121 & 4,121 & 2,588 & 2,588 & 2,035 & 2,035 \\
\hline Adj. $R^{2}$ & 0.425 & 0.430 & 0.549 & 0.549 & 0.425 & 0.432 & 0.573 & 0.573 & 0.426 & 0.427 & 0.521 & 0.523 \\
\hline
\end{tabular}


Table 9: Regulatory changes and CCP costs - pooled regression results for model (5) over two sub-periods

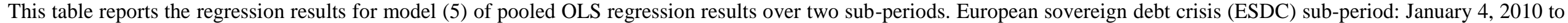

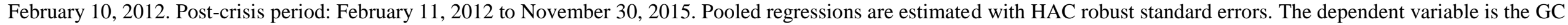

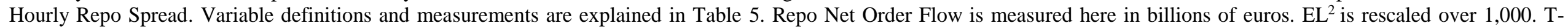
statistics are reported in brackets. $* * *$ indicates $1 \% ; * * 5 \%$; and $* 10 \%$ significance level, respectively. All explanatory variables are lagged by one hour.

\begin{tabular}{|c|c|c|c|c|c|c|c|c|c|c|c|c|c|c|}
\hline \multirow[b]{2}{*}{ Period } & \multicolumn{6}{|c|}{ All Repos } & \multicolumn{4}{|c|}{ CCP-based Repos } & \multicolumn{4}{|c|}{ Bilateral Repos } \\
\hline & \multicolumn{3}{|c|}{ ESDC } & \multicolumn{3}{|c|}{ Post-Crisis } & \multicolumn{2}{|c|}{ ESDC } & \multicolumn{2}{|c|}{ Post-Crisis } & \multicolumn{2}{|c|}{ ESDC } & \multicolumn{2}{|c|}{ Post-Crisis } \\
\hline & (1) & $(2)$ & (3) & (4) & (5) & (6) & (7) & $(8)$ & (9) & (10) & $(11)$ & (12) & (13) & (14) \\
\hline Constant & $\begin{array}{l}-0.082 \\
(-0.02)\end{array}$ & $\begin{array}{l}1.563 \\
(0.45)\end{array}$ & $\begin{array}{l}2.352 \\
(0.61)\end{array}$ & $\begin{array}{c}27.928^{* * *} \\
(18.83)\end{array}$ & $\begin{array}{c}27.044 * * * \\
(13.41)\end{array}$ & $\begin{array}{c}27.374 * * * \\
(12.48)\end{array}$ & $\begin{array}{l}1.797 \\
(0.41)\end{array}$ & $\begin{array}{l}3.368 \\
(0.82)\end{array}$ & $\begin{array}{c}25.733^{* * *} \\
(13.16)\end{array}$ & $\begin{array}{c}25.722 * * * \\
(10.06)\end{array}$ & $\begin{array}{l}0.071 \\
(0.01)\end{array}$ & $\begin{array}{l}1.270 \\
(0.24)\end{array}$ & $\begin{array}{c}28.908^{* * *} \\
(14.22)\end{array}$ & $\begin{array}{c}28.173^{* * *} \\
(10.78)\end{array}$ \\
\hline Lag Bond Supply & $\begin{array}{c}0.545 * * * \\
(8.58)\end{array}$ & $\begin{array}{c}0.386 * * * \\
(5.87)\end{array}$ & $\begin{array}{c}0.383 * * * \\
(5.82)\end{array}$ & $\begin{array}{c}-0.066 * * * \\
(-4.61)\end{array}$ & $\begin{array}{c}-0.062 * * * * \\
(-3.78)\end{array}$ & $\begin{array}{c}-0.062 * * * \\
(-3.80)\end{array}$ & $\begin{array}{c}0.534 * * * \\
(6.44)\end{array}$ & $\begin{array}{c}0.346 * * * \\
(4.16)\end{array}$ & $\begin{array}{c}-0.055^{* * *} \\
(-2.65)\end{array}$ & $\begin{array}{c}-0.055 * * \\
(-2.41)\end{array}$ & $\begin{array}{c}0.552 * * * \\
(5.79)\end{array}$ & $\begin{array}{c}0.421 * * * \\
(4.36)\end{array}$ & $\begin{array}{c}-0.075 * * * \\
(-4.15)\end{array}$ & $\begin{array}{c}-0.072 * * * \\
(-3.52)\end{array}$ \\
\hline Lag Bond BAS & $\begin{array}{c}0.098 * * \\
(2.28)\end{array}$ & $\begin{array}{l}-0.011 \\
(-0.29)\end{array}$ & $\begin{array}{l}-0.014 \\
(-0.38)\end{array}$ & $\begin{array}{l}0.007 \\
(0.61)\end{array}$ & $\begin{array}{l}0.009 \\
(0.82)\end{array}$ & $\begin{array}{l}0.008 \\
(0.79)\end{array}$ & $\begin{array}{c}0.111 * * \\
(2.02)\end{array}$ & $\begin{array}{l}-0.022 \\
(-0.45)\end{array}$ & $\begin{array}{l}0.004 \\
(0.38)\end{array}$ & $\begin{array}{l}0.004 \\
(0.39)\end{array}$ & $\begin{array}{l}0.066 \\
(0.91)\end{array}$ & $\begin{array}{l}-0.016 \\
(-0.28)\end{array}$ & $\begin{array}{l}0.064 \\
(1.53)\end{array}$ & $\begin{array}{l}0.067 \\
(1.56)\end{array}$ \\
\hline Lag Repo Net Order Flows & $\begin{array}{c}3.827 * * * * \\
(6.22)\end{array}$ & $\begin{array}{c}3.393 * * * \\
(5.69)\end{array}$ & $\begin{array}{c}3.361 * * * \\
(5.71)\end{array}$ & $\begin{array}{c}0.614 * * * \\
(4.32)\end{array}$ & $\begin{array}{c}0.610^{* * * *} \\
(4.30)\end{array}$ & $\begin{array}{c}0.610^{* * * *} \\
(4.30)\end{array}$ & $\begin{array}{c}3.896 * * * \\
(5.40)\end{array}$ & $\begin{array}{c}3.406^{* * * *} \\
(4.92)\end{array}$ & $\begin{array}{c}0.663 * * * \\
(4.57)\end{array}$ & $\begin{array}{c}0.662 * * * \\
(4.55)\end{array}$ & $\begin{array}{c}3.161 * * * \\
(3.41)\end{array}$ & $\begin{array}{c}2.946^{* * * *} \\
(3.13)\end{array}$ & $\begin{array}{l}-0.887 \\
(-1.11)\end{array}$ & $\begin{array}{l}-0.891 \\
(-1.12)\end{array}$ \\
\hline Lag Repo Trades & $\begin{array}{c}0.418 * * * \\
(3.41)\end{array}$ & $\begin{array}{c}0.332 * * * \\
(2.76)\end{array}$ & $\begin{array}{c}0.310 * * * \\
(2.61)\end{array}$ & $\begin{array}{c}0.124 * * * \\
(5.14)\end{array}$ & $\begin{array}{c}0.125 * * * \\
(5.20)\end{array}$ & $\begin{array}{c}0.126 * * * \\
(5.17)\end{array}$ & $\begin{array}{c}0.523 * * * \\
(3.57)\end{array}$ & $\begin{array}{c}0.373 * * * \\
(2.61)\end{array}$ & $\begin{array}{c}0.113 * * * \\
(4.61)\end{array}$ & $\begin{array}{c}0.113 * * * \\
(4.68)\end{array}$ & $\begin{array}{l}0.310 \\
(1.43)\end{array}$ & $\begin{array}{l}0.304 \\
(1.39)\end{array}$ & $\begin{array}{c}0.539 * * * \\
(3.72)\end{array}$ & $\begin{array}{c}0.536 * * * \\
(3.72)\end{array}$ \\
\hline Lag Repo Volatility & $\begin{array}{c}1.544 * * * \\
(7.60)\end{array}$ & $\begin{array}{c}0.805 * * * \\
(2.86)\end{array}$ & $\begin{array}{c}0.816 * * * \\
(2.89)\end{array}$ & $\begin{array}{c}0.942 * * * \\
(6.79)\end{array}$ & $\begin{array}{c}0.915 * * * \\
(6.57)\end{array}$ & $\begin{array}{c}0.913 * * * \\
(6.54)\end{array}$ & $\begin{array}{c}1.572 * * * \\
(5.52)\end{array}$ & $\begin{array}{c}0.861 * * \\
(2.36)\end{array}$ & $\begin{array}{c}1.199 * * * \\
(5.89)\end{array}$ & $\begin{array}{c}1.199 * * * \\
(5.59)\end{array}$ & $\begin{array}{c}1.619 * * * \\
(5.73)\end{array}$ & $\begin{array}{c}0.914^{* *} \\
(2.03)\end{array}$ & $\begin{array}{c}0.461 * * * \\
(3.11)\end{array}$ & $\begin{array}{c}0.451^{* * * *} \\
(3.01)\end{array}$ \\
\hline $\mathrm{CCP}$ & $\begin{array}{l}1.321 \\
(0.79)\end{array}$ & $\begin{array}{l}0.849 \\
(0.51)\end{array}$ & $\begin{array}{l}-0.440 \\
(-0.15)\end{array}$ & $\begin{array}{l}-0.939 \\
(-1.49)\end{array}$ & $\begin{array}{l}-0.936 \\
(-1.49)\end{array}$ & $\begin{array}{l}-1.355 \\
(-0.78)\end{array}$ & & & & & & & & \\
\hline Lag EL & $\begin{array}{c}-0.122 * * * \\
(-7.34)\end{array}$ & $\begin{array}{c}-0.111 * * * \\
(-6.62)\end{array}$ & $\begin{array}{c}-0.111 * * * \\
(-6.61)\end{array}$ & $\begin{array}{c}-0.093 * * * \\
(-22.48)\end{array}$ & $\begin{array}{c}-0.093 * * * \\
(-22.39)\end{array}$ & $\begin{array}{c}-0.093 * * * \\
(-22.39)\end{array}$ & $\begin{array}{c}-0.110 * * * \\
(-4.98)\end{array}$ & $\begin{array}{c}-0.103 * * * \\
(-4.68)\end{array}$ & $\begin{array}{c}-0.091 * * * \\
(-17.70)\end{array}$ & $\begin{array}{c}-0.091 * * * \\
(-17.61)\end{array}$ & $\begin{array}{c}-0.130 * * * * \\
(-5.39)\end{array}$ & $\begin{array}{c}-0.118 * * * \\
(-4.63)\end{array}$ & $\begin{array}{c}-0.092 * * * \\
(-13.71)\end{array}$ & $\begin{array}{c}-0.092 * * * \\
(-13.59)\end{array}$ \\
\hline Lag EL ${ }^{2}$ & $\begin{array}{c}0.080 * * \\
(2.35)\end{array}$ & $\begin{array}{l}-0.007 \\
(-0.17)\end{array}$ & $\begin{array}{l}-0.007 \\
(-0.17)\end{array}$ & $\begin{array}{c}0.085 * * * \\
(18.58)\end{array}$ & $\begin{array}{c}0.085^{* * * *} \\
(18.60)\end{array}$ & $\begin{array}{c}0.085^{* * * *} \\
(18.60)\end{array}$ & $\begin{array}{l}0.032 \\
(0.70)\end{array}$ & $\begin{array}{l}-0.046 \\
(-0.91)\end{array}$ & $\begin{array}{c}0.084 * * * \\
(14.33)\end{array}$ & $\begin{array}{c}0.084 * * * \\
(14.34)\end{array}$ & $\begin{array}{c}0.120 * * \\
(2.44)\end{array}$ & $\begin{array}{l}0.030 \\
(0.43)\end{array}$ & $\begin{array}{c}0.080 * * * \\
(11.39)\end{array}$ & $\begin{array}{c}0.080^{* * * *} \\
(11.43)\end{array}$ \\
\hline Margin Costs & & $\begin{array}{c}5.734 * * * \\
(4.10)\end{array}$ & $\begin{array}{c}5.549 * * * \\
(3.70)\end{array}$ & & $\begin{array}{l}0.127 \\
(0.66)\end{array}$ & $\begin{array}{l}0.081 \\
(0.34)\end{array}$ & & $\begin{array}{c}6.347 * * * \\
(3.55)\end{array}$ & & $\begin{array}{l}0.002 \\
(0.01)\end{array}$ & & $\begin{array}{c}4.954^{* *} \\
(2.22)\end{array}$ & & $\begin{array}{l}0.093 \\
(0.36)\end{array}$ \\
\hline Margin Costs*CCP & & & $\begin{array}{l}0.489 \\
(0.48)\end{array}$ & & & $\begin{array}{l}0.067 \\
(0.23)\end{array}$ & & & & & & & & \\
\hline Seasonal Controls & $\mathrm{Y}$ & $\bar{Y}$ & $\mathrm{Y}$ & $\mathrm{Y}$ & $\mathrm{Y}$ & $\mathrm{Y}$ & $\mathrm{Y}$ & $\mathrm{Y}$ & $\bar{Y}$ & $\mathrm{Y}$ & $\mathrm{Y}$ & $\mathrm{Y}$ & $\bar{Y}$ & $\mathrm{Y}$ \\
\hline Time-of-Day Effects & $\mathrm{Y}$ & $\mathrm{Y}$ & $\mathrm{Y}$ & $\mathrm{Y}$ & $\mathrm{Y}$ & $\mathrm{Y}$ & $\mathrm{Y}$ & $\mathrm{Y}$ & $\mathrm{Y}$ & $\mathrm{Y}$ & $\mathrm{Y}$ & $\mathrm{Y}$ & $\mathrm{Y}$ & $\mathrm{Y}$ \\
\hline Observations & 4,446 & 4,446 & 4,446 & 6,156 & 6,156 & 6,156 & 1,858 & 1,858 & 4,121 & 4,121 & 2,588 & 2,588 & 2,035 & 2,035 \\
\hline Adj. $R^{2}$ & 0.430 & 0.449 & 0.449 & 0.549 & 0.549 & 0.549 & 0.432 & 0.458 & 0.573 & 0.573 & 0.427 & 0.440 & 0.523 & 0.523 \\
\hline
\end{tabular}




\section{Table 10: Collateral selection - logit regression results for model (6)}

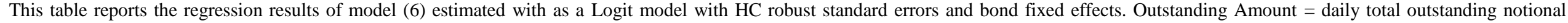

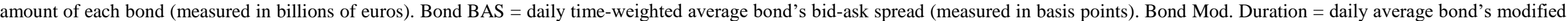

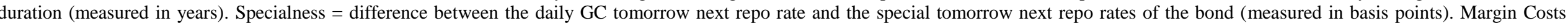

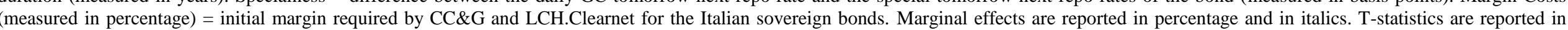
brackets. *** indicates $1 \% ; * * 5 \%$; and * 10\% significance level, respectively. All explanatory variables are lagged by one hour.

\begin{tabular}{|c|c|c|c|c|c|c|c|c|c|c|c|}
\hline \multirow[b]{2}{*}{ Period } & \multirow{2}{*}{$\begin{array}{c}\text { All Repos } \\
\text { Full Sample } \\
04 / 01 / 2010- \\
30 / 11 / 2015 \\
\end{array}$} & \multicolumn{5}{|c|}{ CCP-based Repos } & \multicolumn{5}{|c|}{ Bilateral Repos } \\
\hline & & $\begin{array}{c}\text { Full Sample } \\
04 / 01 / 2010- \\
30 / 11 / 2015\end{array}$ & $04 / 01 / 2010$ & $\begin{array}{l}\text { C } \\
10 / 02 / 2012\end{array}$ & $11 / 02 / 2012$ & $\begin{array}{l}\text { Srisis } \\
30 / 11 / 2015\end{array}$ & $\begin{array}{c}\text { Full Sample } \\
04 / 01 / 2010- \\
30 / 11 / 2015\end{array}$ & $\begin{array}{l}\text { European } \\
04 / 01 / 201\end{array}$ & $\begin{array}{l}\text { jereign Debt } \\
\text { sis } \\
10 / 02 / 2012\end{array}$ & $11 / 02 / 2012$ & $\begin{array}{l}\text { sis } \\
0 / 11 / 2015\end{array}$ \\
\hline $\begin{array}{l}\text { Dep.Var.: Prob of Selection } \\
\text { Ind. Variables: }\end{array}$ & (1) & (2) & (3) & $(4)$ & $(5)$ & $(6)$ & (7) & $(8)$ & $(9)$ & $(10)$ & $(11)$ \\
\hline Constant & $\begin{array}{c}-1.1047 * * * \\
(0.0945)\end{array}$ & $\begin{array}{c}-0.2013^{* *} \\
(0.0918)\end{array}$ & $3.2655^{* * *}$ & $-0.2342^{* *}$ & $-2.0505^{* * *}$ & $-1.5105^{* * *}$ & $-7.0863 * * *$ & $-2.4134 * * *$ & $-1.3113 * * *$ & $-5.6394 * * *$ & $-3.8536 * * *$ \\
\hline Lag Outstanding Amount & $\begin{array}{c}0.0244 * * * \\
(0.0036) \\
0.5216\end{array}$ & $\begin{array}{c}0.0264 * * * \\
(0.0035) \\
0.6169\end{array}$ & $\begin{array}{c}0.0227 * * * \\
(0.0065) \\
0.54489\end{array}$ & $\begin{array}{c}0.0470^{* * * *} \\
(0.0065) \\
1.12941\end{array}$ & $\begin{array}{c}0.0634 * * * \\
(0.0046) \\
1.45231\end{array}$ & $\begin{array}{c}0.0606 * * * \\
(0.0046) \\
1.387\end{array}$ & $\begin{array}{c}-0.0257 * * * \\
(0.0040) \\
-0.2880\end{array}$ & $\begin{array}{c}0.0145^{* *} \\
(0.0060) \\
0.32747\end{array}$ & $\begin{array}{c}0.0049 \\
(0.0059) \\
0.11042\end{array}$ & $\begin{array}{c}0.0060 \\
(0.0072) \\
0.03599\end{array}$ & $\begin{array}{l}-0.0087 \\
(0.0071) \\
-0.05257\end{array}$ \\
\hline Lag Bond BAS & $\begin{array}{c}0.0019 * * * \\
(0.0002) \\
0.0402\end{array}$ & $\begin{array}{c}0.0006 * * * \\
(0.0002) \\
0.0150\end{array}$ & $\begin{array}{c}-0.0013^{* * *} \\
(0.0003) \\
-0.03003\end{array}$ & $\begin{array}{c}0.0005 * * \\
(0.0002) \\
0.01301\end{array}$ & $\begin{array}{l}-0.0005 \\
(0.0003) \\
-0.01105\end{array}$ & $\begin{array}{l}0.0001 \\
(0.0003) \\
0.00179\end{array}$ & $\begin{array}{c}0.0051 * * * \\
(0.0002) \\
0.0571\end{array}$ & $\begin{array}{c}-0.0007 * * \\
(0.0003) \\
-0.01479\end{array}$ & $\begin{array}{c}-0.0022^{* * *} * \\
(0.0003) \\
-0.05069\end{array}$ & $\begin{array}{c}0.0033 * * * \\
(0.0005) \\
0.01943\end{array}$ & $\begin{array}{c}0.0041 * * * \\
(0.0004) \\
0.02449\end{array}$ \\
\hline Lag Bond Mod- Duration ${ }^{2}$ & $\begin{array}{c}0.0441 * * * \\
(0.0115) \\
1.095 \\
0.0070 * * * \\
(0.0009)\end{array}$ & $\begin{array}{c}-0.0884 * * * \\
(0.0109) \\
-1.9499 \\
0.0049 * * * \\
(0.0009)\end{array}$ & $\begin{array}{c}-0.4833 * * * \\
(0.0304) \\
-11.3450 \\
0.0108 * * * \\
(0.0016)\end{array}$ & & $\begin{array}{c}0.1680 * * * \\
(0.0181) \\
3.67180 \\
-0.0077 * * * \\
(0.0014)\end{array}$ & & $\begin{array}{c}0.5931 * * * \\
(0.0159) \\
6.7402 \\
0.0095 * * * \\
(0.0012)\end{array}$ & $\begin{array}{c}0.0517 * \\
(0.0304) \\
1.35220 \\
0.0081 * * * \\
(0.0017)\end{array}$ & & $\begin{array}{c}0.3869 * * * \\
(0.0333) \\
2.261 \\
-0.0079 * * * \\
(0.0028)\end{array}$ & \\
\hline Lag Specialness & $\begin{array}{c}-0.0073^{* * *} \\
(0.0005) \\
-0.1566\end{array}$ & $\begin{array}{c}-0.0072 * * * \\
(0.0006) \\
-0.1674\end{array}$ & $\begin{array}{c}-0.0064 * * * \\
(0.0006) \\
-0.1536\end{array}$ & $\begin{array}{c}-0.0060 \text { *** } \\
(0.0006) \\
-0.14505\end{array}$ & $\begin{array}{c}-0.0088 * * * \\
(0.001) \\
-0.20055\end{array}$ & $\begin{array}{c}-0.0088^{* * *} * \\
(0.0011) \\
-0.20223\end{array}$ & $\begin{array}{c}-0.0059 * * * \\
(0.0006) \\
-0.0659\end{array}$ & $\begin{array}{c}-0.0075 * * * \\
(0.0007) \\
-0.16848\end{array}$ & $\begin{array}{c}-0.0075^{* * *} \\
(0.0007) \\
-0.17006\end{array}$ & $\begin{array}{c}-0.0013 \\
(0.0011) \\
-0.00755\end{array}$ & $\begin{array}{c}-0.0016 \\
(0.0011) \\
-0.00936\end{array}$ \\
\hline Margin Costs & & & & $\begin{array}{c}-0.0163 * * \\
(0.0071) \\
-0.39067\end{array}$ & & $\begin{array}{c}0.0295 * * * \\
(0.0041) \\
0.67494\end{array}$ & & & $\begin{array}{c}0.0113 \\
(0.0073) \\
0.25595\end{array}$ & & $\begin{array}{c}0.0707 * * * \\
(0.0076) \\
0.42507\end{array}$ \\
\hline Seasonal Controls & Yes & Yes & Yes & Yes & Yes & Yes & Yes & Yes & Yes & Yes & Yes \\
\hline Bond Fixed Effects & Yes & Yes & Yes & Yes & Yes & Yes & Yes & Yes & Yes & Yes & Yes \\
\hline Observations & 151,299 & 151,299 & 51,798 & 51,798 & 99,501 & 99,501 & 151,299 & 51,798 & 51,798 & 99,501 & 99,501 \\
\hline Observations (DV = 1) & 102,234 & 93,480 & 30,696 & 30,696 & 62,784 & 62,784 & 26,013 & 18,392 & 18,392 & 7,621 & 7,621 \\
\hline Pseudo R2 & 0.0615 & 0.0566 & 0.0691 & 0.0650 & 0.0686 & 0.0682 & 0.141 & 0.0520 & 0.0511 & 0.0605 & 0.0576 \\
\hline
\end{tabular}




\section{Figure 1: GC repos}

This figure shows the volume-weighted average repo rates (measured in basis points) for Italian ON GC CCPbased repos and bilateral repos versus the ECB deposit rate, the ECB main refinancing operations (MRO) rate and the ECB lending rate in Panel A, and total daily trading volumes (measured in billions of euros) of ON GC CCP-based and bilaterally-traded repos on Italian sovereign bonds in Panel B, over the period from January 4, 2010 to November 30, 2015.

\section{Panel A: CCP ON GC Italian repo rate, bilateral ON GC Italian repo rate and ECB deposit and}

\section{lending rates}

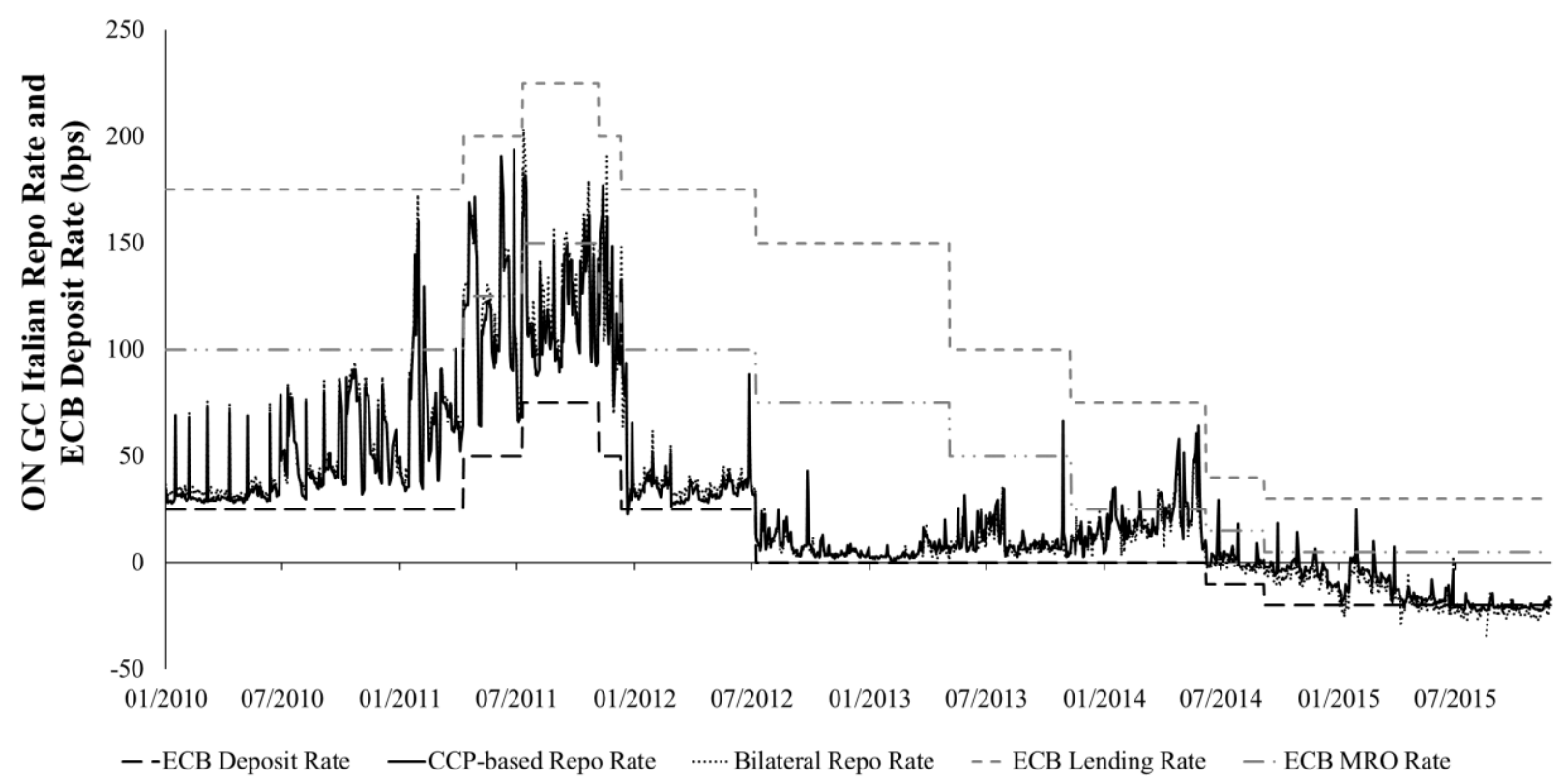

\section{Panel B: Daily trading volumes of ON GC Italian repos}

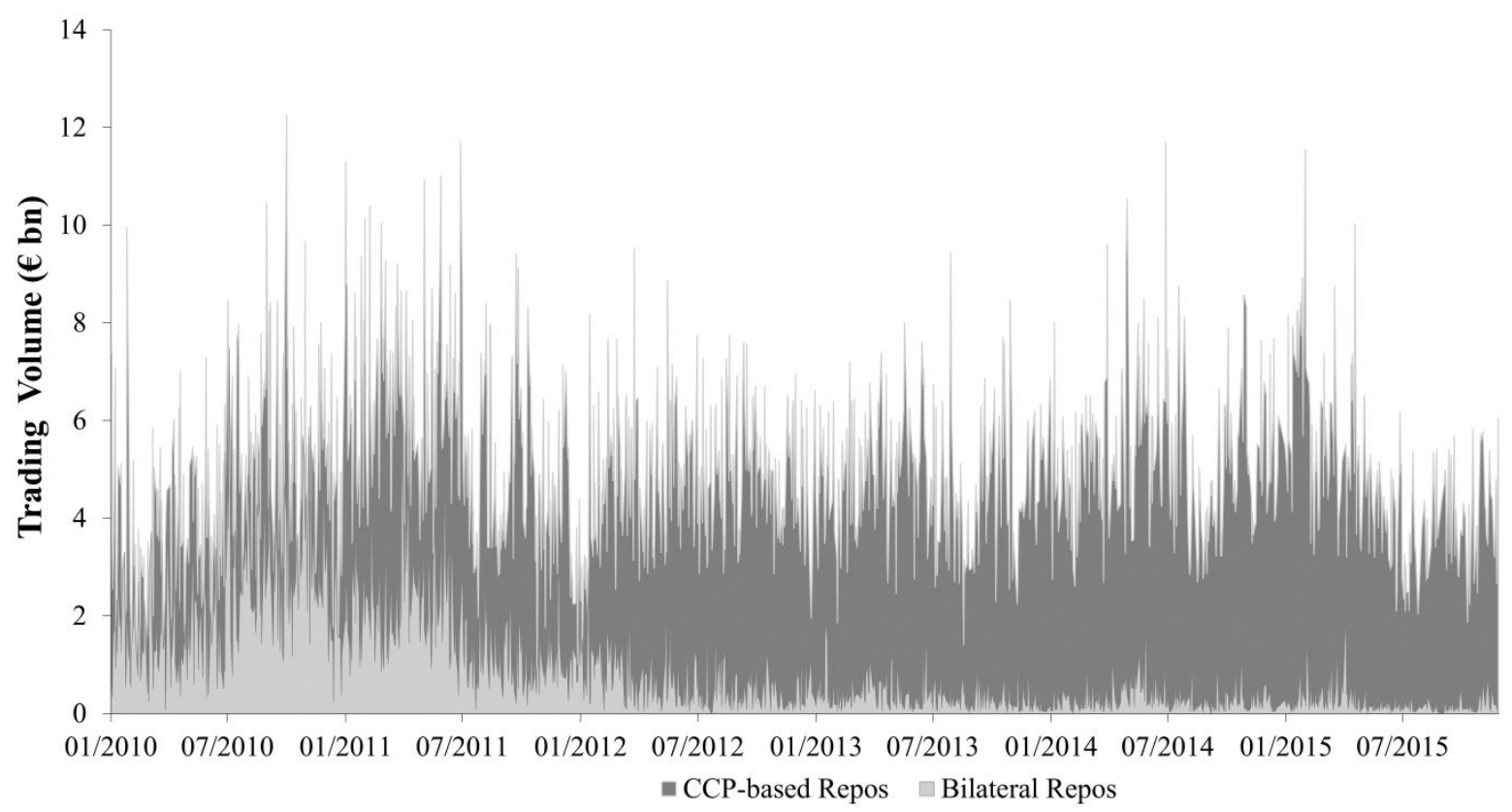




\section{Figure 2: Intraday trading volumes of ON GC Italian repos by hourly band}

This figure shows the total intraday trading volumes (measured in billions of euros) by hourly band of overnight general collateral repos on Italian sovereign bonds. The sample period goes from January 4, 2010 to November 30, 2015. The trading day ends at 12:30 p.m. CET for CCP-based repos and at 3:30 p.m. CET for bilaterally traded repos. The cut-off times for the choice of collateral are 12:45 p.m. CET for CCP-based repos and 3:45 p.m. CET for bilaterally-traded repos. Total intraday trading volumes of overnight general collateral repos on Italian sovereign bonds (measured in billions of euros) are calculated by hourly band over the period from January 4, 2010 to November 30, 2015.

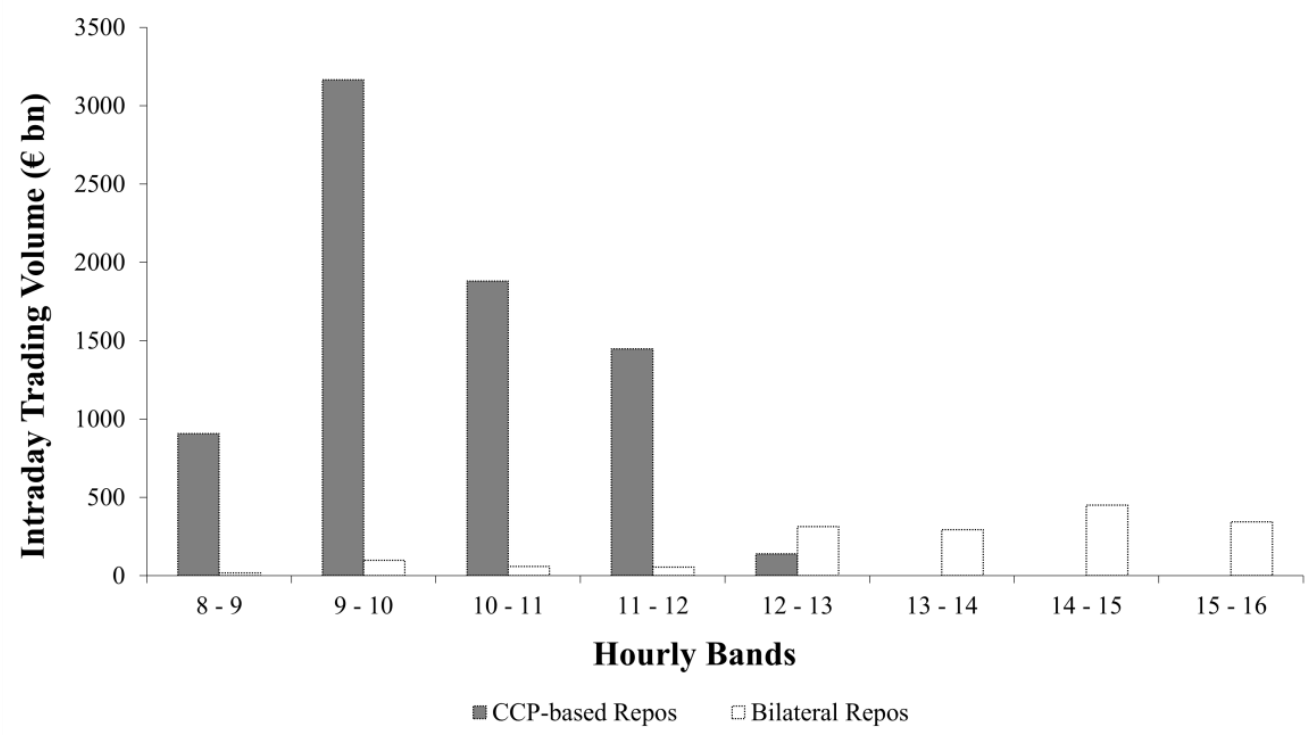

\section{Figure 3: Collateral bond supply and outstanding amount}

This figure shows the daily average of Bond Supply (measured in $€$ millions) versus the total outstanding amount of all Italian sovereign bonds (measured in $€$ millions), for bonds used in CCP and bilateral repos over the period from January 4, 2010 to November 30, 2015

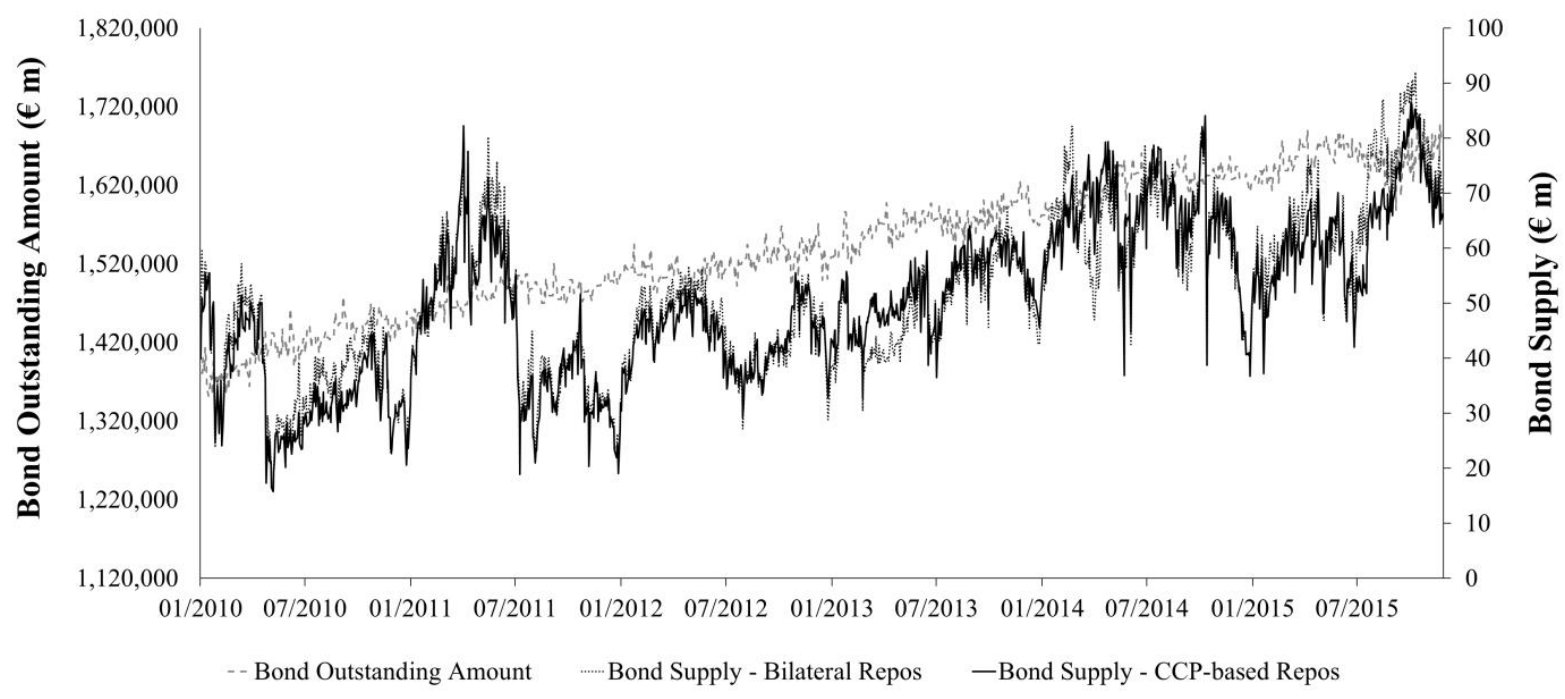




\section{Figure 4: Estimated patterns of hourly CCP and bilateral repo spread over two sub- periods}

The figure shows the estimated pattern of hourly repo spreads (measured in basis points) in Panel A for CCPbased repos and in Panel B for bilaterally traded repos over the two sub-periods with $95 \%$ confidence bounds. The model estimated in both Panel A and B is model (5), and the main results are reported in Table 8. The independent variables are assumed at their sample mean values.

\section{Panel A: CCP-based Repos}

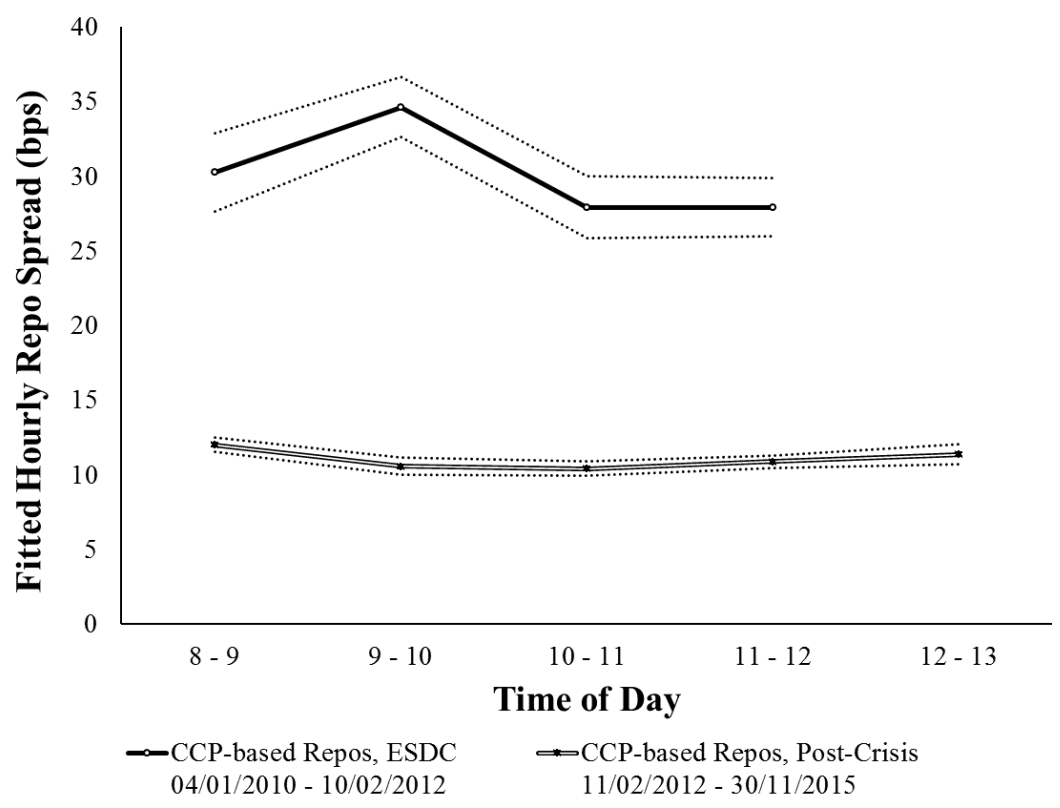

\section{Panel B: Bilateral Repos}

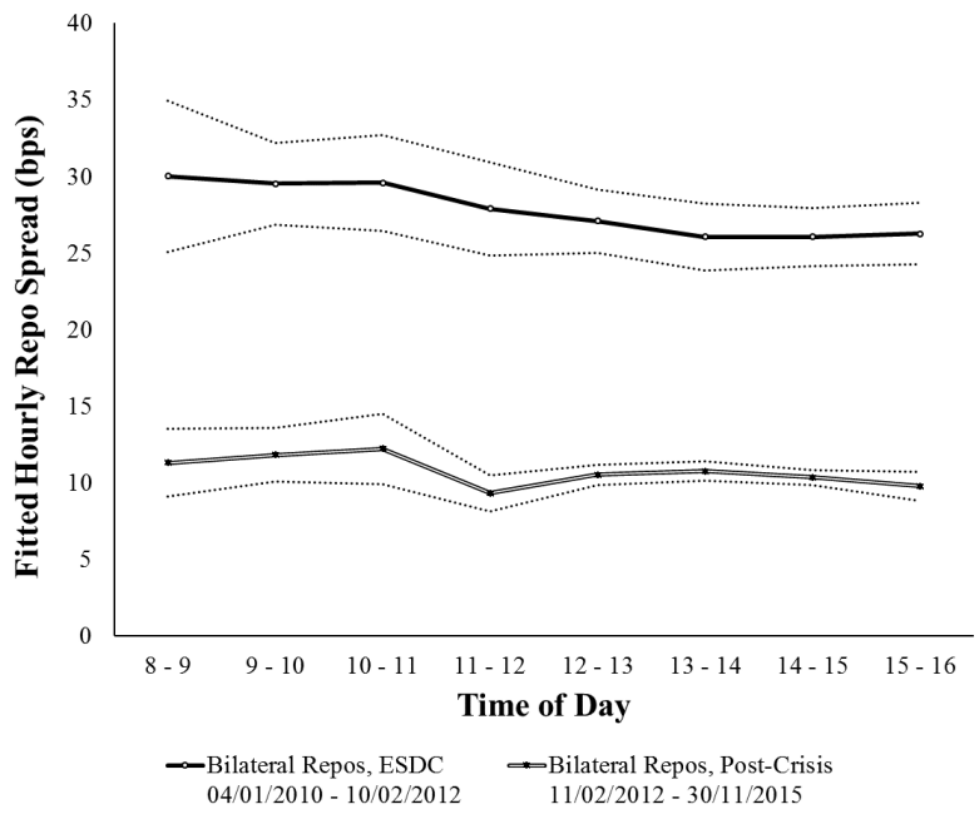

